\title{
Why do Sovereign Borrowers Post Collateral? Evidence from the 19th Century Marc Flandreau ${ }^{\dagger}$, Stefano Pietrosanti ${ }^{\ddagger}$, and Carlotta E. Schuster**
}

\section{Working Paper No. 167}

\author{
October $7^{\text {th }}, 2021$
}

\begin{abstract}
This paper explores the reasons why sovereign borrowers post collateral. Such behavior is paradoxical because conventional interpretations of collateral stress repossession of the assets pledged as the key to securing lenders against information asymmetries and moral hazard. However, repossession is generally difficult in the case of sovereign debt and in some cases impossible. Nevertheless, such sovereign "hypothecations" have a long history and are again becoming very popular today in developing countries. To explain sovereign collateralization, we emphasize an informational channel. Posting collateral produces information on opaque borrowers by displaying borrowers' behavior and resources. We support this interpretation by examining the

\footnotetext{
${ }^{\dagger}$ Howard S. Marks Professor of Economic History, University of Pennsylvania, the Wharton School and CEPR. Corresponding author:mfl@sas.upenn.edu.

${ }^{\ddagger}$ Research Fellow, Bank of Italy.

- Economist, UNCTAD

* An earlier version of this paper previously circulated as "The Mystery of Collateral Clauses: Sovereign Debt, Hypothecations and Financial Information in the Mid-19th Century (1849-1875)". Marc Flandreau acknowledges generous financial support from the Institute for New Economic Thinking. The authors wish to express special thanks to Matthieu Chavaz, for collaborating on the earlier draft and sharing the initial codes, and to Geoffroy Legentilhomme, for exceptional research assistance. We also wish to thank Emilia Bonaccorsi di Patti, Giuseppe Cappelletti, Elena Carletti, Thomas Ferguson, Rodrigo Garcia-Verdu, Gary Gorton, Christine Kadama, Guillermo Ordoñez, Giorgia Piacentino and Anatoli Segura Velez for fruitful discussions; the participants to the Sixth Associazione per la Storia Economica Annual Meeting for the comments and Andrea Papadia for the discussion. All errors are our own. The opinions expressed do not necessarily reflect those of the Bank of Italy, the Eurosystem, the UNCTAD and their staff. All errors are our own.
} 
hypothecation "mania" of 1849-1875, when sovereigns borrowing in the London Stock Exchange pledged all kinds of intangible revenues. Yet, at that time, sovereign immunity fully protected both sovereigns and their assets and possessions. Still, we show that hypothecations significantly decreased the cost of sovereign debt. To explain how, we stress the pledges' role in documenting sovereigns' wealth and the management of revenue streams. Based on an exhaustive library of bond prospectuses collected from primary sources, matched with a panel of sovereign bond yields and an innovative measure of sovereign fiscal transparency, we show that collateral minutely described in debt covenants served to document and monitor sovereign resources and development prospects. Encasing this information in contracts written by lawyers served to certify the quality of the resulting data disclosure process, explaining investors' readiness to pay a premium.

\section{https://doi.org/10.36687/inetwp167}

JEL codes: N20, G24, K12, K33, H63

Keywords: Collateral, Information, Sovereign debt, Informal enforcement, Financial innovation, Contract innovation. 


\section{Introduction}

In conventional analysis, contracts exist within formal institutional frameworks built on coercive enforcement (North et al., 1990). The posting of collateral in corporate lending provides an instance. Collateral is a vital instrument for ensuring the performance of debt contracts (Demarzo, 2019 , for a recent survey). Theory interprets it as a tool that can mitigate information asymmetry and moral hazard in credit relationships. Collateral is a costly signal; as such, it helps borrowers disclose their quality to lenders ex-ante (e.g. Besanko and Thakor, 1987). Moreover, increasing borrowers' stakes ex-post (Bernanke and Gertler, 1989; Kiyotaki and Moore, 1997), it can limit the incentive of insiders to mismanage resources (Smith and Warner, 1979) and protect investors against dilution (Donaldson, Gromb, and Piacentino, 2020). ${ }^{1}$ A consequence is that the posting of collateral does enhance debt liquidity, making debt less "information-sensitive" by decreasing the need to investigate the project behind the debt (Gorton and Ordonez, 2014; Dang et al., 2017; Gorton and Ordoñez, 2020).

The reliance on collateral as an instrument to produce information insensitive debt has a long history. For instance, the role played by land registries in sustaining the development of private credit markets in Britain is well-known (Ito, 2013). In today's capital markets, investors achieve collateralization of large loans and financial transactions with the help of a supporting institution, the so-called Central Securities Depositories (CSD), a system securing beneficiaries by storing collateral and updating ownership records in real time. CSDs are legal creatures: They operate as trustees and ensure that loans are automatically enforced. Research has documented a link between the quality of the rule of law and the performance of collateral as an institution. A stronger rule of law improves the quality of CSDs, ensures a higher degree of creditor protection, and ultimately enhances access to credit (Degryse et al. 2020). Calomiris et al. (2017) show that poor quality of laws regulating collateralization and repossession impedes the smooth operation of CSDs encouraging alternative strategies, such as reliance on immovable collateral, thereby constraining lending.

Against this backdrop, a significant phenomenon is the recurrent use of collateral in sovereign lending. Recently, international policymakers, economists and lawyers have noted an increasing trend in collateralized lending to poor and developing countries (IMF/World Bank 2020). For instance, a recent study by Gelpern et al. (2021) underscores the extent of collateralized lending by Chinese agencies (see also Horn et al., 2019). ${ }^{2}$ This widespread tendency is puzzling. Since

\footnotetext{
${ }^{1}$ For empirical investigation of these mechanisms see Jiménez, Salas, and Saurina (2006); Berger, Frame, and Ioannidou (2011); Berger et al. (2011); Cerqueiro, Ongena, and Roszbach (2016).

${ }^{2}$ Similar loans often come in the form of project financing secured by the hypothecation of specific revenues. Horn et al. (2019) estimates direct Chinese commitments in the order of 560 billion \$, for about 2,000 loans. Gelpern et al. (2021) reconstructs contract information for 100 such loans. The last paper shows that about 26
} 
sovereigns are involved, the conventional role of collateral as an enforcement mechanism is questionable. An even bigger puzzle is that such collateral clauses have a long history. According to Coleman (1936), they appeared during the early modern period, as sovereign borrowers delegated to their creditors control of some asset or fund, or earmarked a given tax income stream as guarantee. Daru (1821, I, 203-4) gives an early instance (perhaps the first) consisting in a $12^{\text {th }}$ century loan by the sovereign Republic of Venice explicitly secured by a salt right and seigniorage (Mint) revenues. ${ }^{3}$

In this paper, we seek to understand the role for collateral pledges when ex-post enforcement is difficult or impossible. The answer we provide is that collateral is valuable, not as a repossession mechanism but as an information production technology. To establish the validity of our claim, we focus on an environment in which we can rule out conventional interpretations for collateralization. The case study we examine thus serves to explore collateralization in the context of a controlled experiment, in as much as, by construction, it shuts out traditional explanations (the CSD interpretation). Collateralization nonetheless took place on a wide scale and that it decreased the cost of sovereign debt shows that facts support our alternative interpretation.

The context we exploit to this end is that of sovereign debt in the 19th-century. Previous authors have emphasized sovereign hypothecations as a boilerplate clause in debt contracts issued by foreign governments in the London stock exchange (Jenks 1927). Fishlow (1985, p. 400) speaks of the widespread habit of pledging "customs, land-holdings, and other natural resources." However, repossession of the collateral was impossible in case of non-performance, owing to the extreme form of sovereign immunity that prevailed at this point. Sovereigns could not be sued in court. In the language of a $19^{\text {th }}$-century legal textbook: "Foreign states, and those persons in them who are called sovereigns, whether their title be emperor, king, grand-duke, or any other, and whether their power in their states be absolute or limited, cannot be sued in England on their obligations" (Westlake, 1858, p.226). Modern legal scholarship speaks of an age of "absolute sovereign immunity" (Weidemaier, 2012). In fact, as we demonstrate, sovereign collateral was immune too. Absolute immunity extending to the collateral allows us to study the use of hypothecation independently of enforcement and highlights the stand-alone importance of the mechanism we suggest.

The value of the historical setup for our investigation, as opposed to a modern one, is two-fold. On

percent of loans include some form of security arrangement. Moreover, 30 percent of contracts (for 55 percent of the funds tracked by the authors) include informal collateralization via escrow accounts where the borrower must make timely payments.

${ }^{3}$ Other Italian Republics made extensive use of similar arrangements borrowing on the security of various rights. For instance, Genova's "luoghi” were secured by the pledging of public revenues (Fratianni and Spinelli 2006). The beginning of sovereign debt in France is famously ascribed to an arrangement between King Francis I and the City of Paris in the early $16^{\text {th }}$ century, whereby the king ceded royal revenues to his creditors (Vührer 1886, Cauwès 1895a, 1895b and 1896, Vammale-Sabouret 2008). Hirst (1910) argues that following the Glorious Revolution, the British parliament pledged excise duties, levies on East India goods, and wine duties as collateral for a succession of loans made during the 1690s. Finally, according to Dewey (1934), Revolutionary America mortgaged specific revenue sources when first borrowing abroad. 
the one hand, as is well known, the modern position of sovereign immunity is significantly less clear-cut than the historical context we study. Moreover, the current trend in sovereign hypothecation is a relatively recent phenomenon involving new borrowers and new lenders (China), so that data is severely limited. Yet, the present picture on enforcement bears strong similarities with the historical one. As Gelpern et al. (2021) underline, "it bears emphasis that our study does not systematically address contract implementation and enforcement, for which there is limited anecdotal evidence". At the same time, the authors note the parallel between present contract features and $19^{\text {th }}$-century ones, stressing the relevance of our setting of choice -- "One needs to go back to the 19th and early 20th-century to find similar security arrangements in sovereign lending."

Drawing on primary archival sources, hand-collected data and $19^{\text {th }}$-century legal sources, we expose a situation where we need a theory of collateral independent of repossession mechanisms. Our central claim is that in information poor environments such as the one we examine (and we suspect, such as the modern setup provides), collateralization retains value as a technology to reveal information in structured, transparent ways. The prototypical $19^{\text {th }}$-century sovereign collateral clause's objective was to setup a comprehensive "observing" institution designed to document and monitor the borrower directly. Such collateral clauses consisted of a carefully crafted display that contributed valuable information on the borrower's resources, thus limiting information asymmetries. Moreover, revenue pledges set clear expectations for the payment of interest and principal, hence for borrower performance and behavior. Thus, such arrangements provided for synchronized disclosure of information, facilitating lenders' coordination and curbing borrowers' moral hazard. We suggest these two aspects explain the extensive use of collateral in enforcement poor contexts. Compared to approaches that underscore the importance of property rights in development our study emphasizes the importance of efforts to construct reliable information institutions. ${ }^{5}$

Our interpretation also departs from previous explanations of sovereign hypothecations used in the $19^{\text {th }}$ and $20^{\text {th }}$ centuries. These have typically assumed away the problem in one of two ways. On the one hand, classic works (Jenks, 1927; Coleman, 1936) and contemporary legal scholarship (e.g. Buchheit and Pam, 2004) have suggested that sovereign hypothecations were a scam, in fact false publicity thrown in prospectuses to rouse unwarranted beliefs in enforcement. ${ }^{6}$ On the other, a recent strand of scholarship has suggested that sovereign collateralizations might have exploited characteristics of the assets pledged, such as their being movable or tradable goods sold in foreign countries and that could be seized by creditors (Vizcarra, 2009; Chabot and Santarosa, 2017). This

\footnotetext{
${ }^{4}$ Gelpern et al. (2021, p.6 and 8).

${ }^{5}$ E.g. North and Weingast, (1989); La Porta et al., (2000); Djankov et al., (2003).

${ }^{6}$ For example, Buchheit and Pam (2004, p.20), states that “...bonds would frequently be described as benefiting from some form of security or guarantee: a vaguely-worded interest in the proceeds from the sale of guano, for example ... In practice, the ostensible security for these bonds was frequently of very little help in getting the bonds paid in the face of a default..." We claim, instead, that this was not due to the clauses being a ruse, just to the fact they targeted a purpose different from security upon default.
} 
would have made the pledge enforceable. In fact, we show that although occasionally movable, sovereign-owned collateral was immune, even if literally located within walking distance of a British court. Moreover, investors rationally understood the non-enforceable character of the pledges. The power of sovereign immunity was known to every international lawyer and explained to the investing public by reputable journals. What is more, using primary evidence discovered in the archive of the London stock exchange, we demonstrate that when policymakers moved to regulate hypothecations, they solely attempted to improve informational content by creating liability for false information in the data contained in prospectuses, rather than for misleading investors into believing that repossession would occur in reality.

The gist of the empirical evidence in favor of our argument that sovereign hypothecations were not about repossession rests on an exploration of the link between opacity and hypothecation. We show that sovereigns selected into the use of hypothecations when they were fiscally opaque. We argue that the hypothecation procedure enabled them to create an alternative mechanism whereby both the ability and willingness to pay could be observed. First, on the basis of a systematic examination of each individual contract, we show that each collateral pledge set the stage for minute debt repayment management, providing early warnings in case of distress and thus allowing bondholders to coordinate bond sales, ultimately protecting creditors' rights in case of verifiable deviations from set expectations. Second, the mechanism enabled to monitor overborrowing. Sovereigns that ran out of collateral either had to stop borrowing or were bound to repledge collateral, which amounted to a dilution of previous rights - a tangible signal of debt approaching unsustainable levels, as no new revenue source could be certified. In other words, to demonstrate the role of information production and the management of parties' expectations as important empirical drivers for the use of collateral, we provide evidence that sovereign collateral clauses constituted a method of certified information sharing, which eased the borrower's distributed monitoring.

To demonstrate all this, we exploit fine-grained information from the universe of sovereign debt issues in the London Stock Exchange (LSE) during the mid-19 ${ }^{\text {th }}$-century sovereign debt boom, which led to a "hypothecation mania" (1849-1875). The dataset, hand-retrieved from archival and printed sources, completed with matching prices, and country information on fiscal transparency, spans the population of sovereign debt issues of the time, consisting of 117 sovereign bonds, coupled with a panel of yearly yields-to-maturity spanning from 1864 to 1875 . While this is large by historical standard and larger than the modern sample in Gelpern et al. (2021), we alleviate limits on the size of the dataset by supplementing the analysis with focused, high-frequency case studies and event analyses. An advantage of working with a case study such as this is the detail and precision of the database, as well as the contextual inference it permits. Such detail enables us to engage in a variety of empirical exercises, which, once pieced together, provide a uniform picture.

To the best of our knowledge, no work extant thinks of collateral the way we do here. However, our interpretation has close ties with existing areas of scholarship from which it draws and to which 
it contributes. First, it is related to the literature on contracts innovation and contracting under informal enforcement, which emphasizes creditor coordination. ${ }^{7}$ Homogeneous disclosure of news about individual loans limits the threat of insider exploitation in case of non-performance, a precious service in the case of high-risk securities. Second, we suggest that the detailed workouts built into collateral clauses acted as informal covenants on sovereign behavior. In this sense, our study is related to the covenant literature documenting an alternative way to achieve a similar borrowers' monitoring mechanism literature (e.g. Garleanu and Zwiebel, 2009; Chava, Kumar and Warga, 2010; Bradley and Roberts, 2015). ${ }^{8}$

A further important connection is with the literature on the role of information cascades and media frenzies in driving asset prices, in the style of Veldkamp (2006). In her model, high payoffs and volatility drive up the value of collecting information, encouraging information supply. High payoff and volatility is a fitting description of the $19^{\text {th }}$-century sovereign bond market conditions. Precisely at that time, new technologies like railways, associated with intensified trade and financial globalization, arouse savers' interest in novel investment opportunities. However, a key problem at the time was the documentation of performance. ${ }^{9}$ Against this backdrop, collateralization acted as a media, producing information on otherwise opaque borrowers and boosting prices. We suggest this explains the great vogue enjoyed by such clauses, as they enabled many borrowers with limited transparency to access capital markets. While this explains the suspicion, at the time and afterwards, that manipulation was involved, we suggest that the clauses achieved a legitimate end in a difficult informational context.

Finally, and most importantly perhaps, our interpretation and findings provide relevant insights on the economic significance of collateral beyond the sovereign case. Conventional theoretical and empirical studies of collateral in a corporate setup struggle to disentangle information from enforcement because by nature, in a CSD-supported regime, the two mechanism dovetail one another. Against this backdrop, what a study of sovereign collateralization contributes is an ability to disentangle the two logics, which of course sheds light on the corporate context as well. In fact, our findings align with empirical results by Gambacorta et al. (2020) on how new information technologies reduce the incidence of collateral in lending to small and opaque borrowers. If, as we argue, collateral also has a role as information technology and enforcement problems are less extreme but still present in corporate lending, it is not surprising that the inception of better

\footnotetext{
${ }^{7}$ Theoretical works include Greif, Milgrom, and Weingast (1994); Börner and Hatfield (2017); Barron and Guo (2021); Empirical works include Greif (1992); Ryall and Sampson (2009); Vuillemey (2020); Miao, Miu and Noe (2021).

8 "Informal" as again there was no court enforcing an acceleration clause, only the risk of bond sales upon news of violation.

${ }^{9}$ It is interesting to note how what we describe is basically the symmetrical situation to the one discussed in Eichengreen (1994). Eichengreen suggests that a developing country with good credit (Russia) used its credit worthiness to turn to its budget as an informational interface to reduce information asymmetries. In clear, creditors needed only monitor the Russian state, not the railway companies that Russian loans funded. In our case, countries without an established credit sought to boost their credit worthiness by collateralizing their development potential, explaining the need for displays.
} 
information technologies results in a substitution of "data for collateral" documented by the authors.

Methodologically, we organize the paper in a deductive way. We begin by establishing that we can isolate collateralization and court enforcement in our data. We do so by demonstrating how the performance of the doctrine of sovereign immunity during the $19^{\text {th }}$ century protected even movable collateral. We also reject the view that hypothecations were a scam by showing that markets failed to react to a widely covered verdict that confirmed that collateral was immune. This means that investors had already priced the absence of enforcement.

Next, we introduce our dataset of sovereign contracts, which we examined individually, and deconstruct their fine legal underpinnings. The vast majority of the collateral clauses we find in $19^{\text {th }}$-century sovereign debt contracts were entirely silent regarding the enforcement mechanism (unlike what would happen with CSD-like hypothecations). By contrast, they took great pains to detail the security, quantify its value and/or revenue streams, location, and prospects, and, in particular, they spelt out the obligations of intermediaries and sovereigns regarding the interest payment process enabling creditors to get synchronized advance notice of payment problems. We also display some instances where collateralization, drawing on peculiar circumstances and clever legal design, approximated the conventional logic of securing the lender by enabling (a measure of) repossession. This proves that if they wanted to, lawyers could design CSD-like collateralization and conversely, that if they did not, it was because collateral served other purposes.

Next, we show that non-enforceable hypothecations were valuable. Using country fixed effects to control for selection, we estimate that hypothecated bonds traded at a yield of approximately 100 basis points lower than the country's average non-hypothecated bond. In other words, lenders were prepared to pay a premium for hypothecated securities holding country-risk fixed, even though they knew they would not be able to repossess the asset. Such premium is economically significant, amounting to 30 percent of the total premium commanded by a minority of enforceable collateralizations we identify.

Last, we present evidence suggestive that the value of sovereign hypothecations resulted from the information collection regime they established. Our first exhibit is the effect of the availability of fiscal information on hypothecation decisions. After piecing together available fiscal information from contemporary sources, we show that countries most likely to collateralize were countries less likely to provide official budget figures. This negative correlation (substitutability) points to the fact that pledges, even if non-enforceable, played a role in mitigating asymmetric information. Our second exhibit is evidence of substitutability between collateral clauses and other established certification technologies, such as employing a reputable underwriter's services (Chemmanur and Fulghieri, 1994). Opaque countries with a stable connection to a prestigious intermediary had almost no use for hypothecations.

Finally, we use archival and narrative evidence on regulatory responses to perceived exploitation to test for our interpretation that hypothecations served to disclose information, as opposed to the 
alternative that they were a scam. This occurred in 1872 following revelations by The Economist that hypothecation information in one prospectus had been doctored. This revelation led to a Parliamentary investigation, spurred by concerns about information manipulation. We manage to trace the response to the archive of the London stock exchange and show that the subsequent regulatory reform did not lead to the forbidding of collateral clauses, but criminalized disclosure of false factual data through such clauses.

We structure the rest of the paper as follows. Section II presents evidence that the standard sovereign collateral clause did not provide grounds for repossession and that bondholders knew this. Section III elaborates on the historical background and the theoretical references guiding our analysis. Section IV describes our library of prospectuses and measures of fiscal transparency. Section V shows evidence that nevertheless hypothecations where valued by bondholders, linked to information production and that the result of a "hypothecation panic" started in 1872 was not to ban non-enforceable hypothecations, but to criminalize false information in bond prospectuses. Section VI presents multiple robustness tests. Section VII concludes.

\section{The Sovereign Debt Hypothecation Puzzle}

\section{II.1 Sovereign Hypothecation Not a Security}

In the existing literature, the case of Peru's hypothecation of guano, a natural fertilizer, has attracted significant interest. Peruvian loans issued in London during the 1850s, 1860s and 1870s pledged as security guano from the country's rich state-owned repositories in the Chincha Islands. ${ }^{10}$ Vizcarra (2009) discusses the economics of guano hypothecations and Chabot and Santarosa (2017) mention it. Chabot and Santarosa (2017) focus instead on another hypothecation from the same period, the Spanish Quicksilver Mortgage Loan of 1870, which mortgaged the stateowned quicksilver mine located in Almaden, Spain. Both Vizcarra (2009) and Chabot and Santarosa (2017) argue that the rationale for these hypothecations hinged on the movable character of the pledge. Sovereign debt hypothecations secured creditors, because, being export commodities, guano and mercury could be seized abroad. For instance, according to (Vizcarra, 2009 , p.359; 376), the credibility of the guano hypothecations stemmed from the fact that, once exported, it "did not involve meddling by the Peruvian government" because "guano revenues were collected at the point of sale abroad" that is, "outside the jurisdiction of the Peruvian government." This would have ensured that the "operation was clean" in that "it did not involve meddling by the Peruvian government." This means that guano and other hypothecations amounted to the creation of a genuine CSD-like arrangement.

In fact, this is an incorrect reading. Guano remained property of the Peruvian government even

\footnotetext{
${ }^{10}$ Clarke (1859, p.454) credits Isaac Lyon Goldsmid, a prominent contemporary financier, for contributing to collateral clauses' initial design in 1849. This would have inspired copycats in other countries, though there is evidence of an earlier use of hypothecations in debts issued in London during the boom of the 1820s (Flandreau, 2021).
} 
when located abroad. This was because, under the admitted law of nations that informed the jurisprudence of leading powers, the agents of states inherited their principal's privileges. This means that agents of sovereigns were immune and British court could not control their behavior as agents. The implication is that, even when sitting on a dock in London, guano was still protected from the reach of creditors by Peru's sovereign immunity, as long as the agent held it. If sold to a third party, the same was true, because the sovereign had the power to dispose of its own assets and the money the agent received was immune too. Agents' protection was a powerful principle at the time. It was well known, and it comes out very clearly from authoritative 19th century legal sources, such as Chitty (1841, p.278-9) and Story (1839). The prestige and influence of the latter textbook is widely attested. For instance a judge in an influential case quoted Story (1839, p.306) to the effect that "in ordinary course of things, an agent, contracting on behalf of the government, or of the public, is not personally bound by such a contract, even though he would be by the terms of the contract, if it were an agency of a private nature". ${ }^{11}$

Conveniently, the value of hypothecations was tested in British courts of justice. Smith v. Weguelin, a Chancery case, started in 1867, when a Peruvian bondholder, Smith, sued the agents of Peru Thomson, Bonar and Co. and the Peruvian company doing the shipping, the Compañia de Consignation de Huano en la Gran Bretaña. ${ }^{12}$ Smith alleged that the agents had not amortized the amount stipulated in the contract. This had resulted in depressed prices and a loss for him. He was asking the court to direct Thomson, Bonar and Co. to adhere to the contract. There were no difficulties other than legal, since the deposits were physically in London. Yet, aware that his clients were on shaky grounds, plaintiffs' counsel John Westlake did not just try to get the contract enforced, since he knew that the defendants, as agents of Peru, were immune. He invented a novel theory instead, whereby guano contracts amounted to the creation of an implicit deed of trust established by the government of Peru for the benefit of the bondholders (the "assignees" of the deed of trust) and of whom the agents of Peru were "trustees". Therefore, it was competent to the court to direct them to do what was in the interest of bondholders and for which the guano contract had provided by "hypothecating" the assets. In clear, Westlake was making the case those guano hypothecations were a CSD-like arrangement, a trust to carry collateral and secure lenders. ${ }^{13}$

On May 27, 1869, an angry judge Lord Romilly dismissed the case with costs for the plaintiffs. The low ground for the decision was that the Judge felt the complaint lacked merit. However, the judge cared to stress that even if the charge had been valid the result would have been the same. In both cases, guano held by Peru's agents was immune as agents' immunity was a superior principle. If he had delivered a different ruling, he explained, he would have enabled every creditor of a defaulted state to seek the help of British courts and enforce collateral. As he put it, the decision would "enable a bondholder by the aid of the Court of Chancery practically to declare war against

\footnotetext{
${ }^{11}$ Goodwin v Robarts, (1874-75) L.R. 10 Ex. 337, on p. 344.

12 Smith v. Weguelin, 1869, L.R. 8 Eq. 198, p. 212-214. Vizcarra (2009) and Chabot and Santarosa (2017) do not discuss this verdict. Even so, there is previous coverage of it in older scholarship concerned with sovereign insolvency. To this end, see Borchard (1951, p.67).

${ }^{13}$ Smith v. Weguelin, L.R. 8 Eq. 198, p. 204.
} 
a foreign country." 14 The judge scoffed at the deed of trust theory, deriding it as the "most singular part of the argument." He could recognize a deed of trust when he saw it but in no place in the covenant was there evidence that the sovereign had granted to creditors "the right of intercepting or dealing with the guano."

The press waxed on. The prestigious Economist, which had been a vocal critic of hypothecations, declared that this merely confirmed their earlier view that "hypothecation of certain property is really no additional security" and that "creditors of a foreign government cannot enforce their rights by attaching property hypothecated to them." The same did the Times, which printed the full verdict including the Judge's damning words, and the provincial press reprinted the material. ${ }^{15}$ Later decisions did also confirm the influence of the Smith verdict immediately acquired. ${ }^{16}$

\section{II.2 Hypothecations Not a Scam}

There remains the possibility that despite this, sovereigns and underwriters devised hypothecations to arouse unwarranted beliefs regarding enforcement. This is the claim of a classic paper by Coleman (1936), showing a correlation between collateralization and risk in the context of the hypothecations used in 1920s NYSE-issued sovereign bonds. Coleman concludes that collateral clauses were a "phantom security" - in fact a fraud. A similar view is shared by Buchheit and Pam (2004), observing how collateral clauses were of little help upon sovereign default. Indeed, Buchheit and Pam (2004, p.21) quote Allen W. Dulles' testimony in front of the U.S. Securities and Exchange Commission, stating that "I have reached the conclusion the pledges of revenues are not worth the paper they are written on, on foreign loans, unless the revenues are collected and disbursed by persons other than the debtor" ${ }^{17}$ Such arguments can be easily reconciled with the literature stressing the importance of behavioral biases and limited rationality in investment (for a review, see Hirshleifer, 2015).

Neglect of risk due to limited attention can drive investment behavior with sizable effects on securities prices (e.g. Daniel, Hirshleifer, and Teoh, 2002; Baron and Xiong, 2017). Moreover, such biases create incentives for financial innovation (Gennaioli, Shleifer, and Vishny, 2012), pushing financial entrepreneurs to cater to investors' behavioral biases. If investors prefer safe cash flows, but also neglect specific risks, financial entrepreneurs will devise instruments exposed

\footnotetext{
${ }^{14}$ Moreover, he added, "if the Court of Chancery could seize all the guano belonging to the Peruvian government it might as well seize Peruvian vessels under the article [of the contract] which declares that all the other property and sources of revenue of the Republic should be applicable to payment of the loan."

15 The Economist, (May 29, 1869, p. 626); Times, May 28, 1869; Extracts of the Economist's article were reprinted in several provincial newspapers such as the Western Daily Press, the Bradford Observer, etc. (Western Daily Press, May 31, 1869; Bradford Observer, May 31, 1869).

${ }^{16}$ Following Peru's missing payment of the coupon of its guano debts in January 1876, bondholders Twycross and Croyle tried their luck in chancery and sued the then agent of Peru, Dreyfus, but with no success, the court deciding that the case was indistinguishable from Smith. See Twycross v Dreyfus (1876 T. 177). Croyle v Dreyfus (1876) is a twin case that does not have an independent court report, but contemporary media and some legal discussions mentioned it.

${ }^{17}$ Allen W. Dulles gave this testimony in the late 1930s in his capacity as a partner in the Sullivan \& Cromwell law firm, during the investigations focusing on the 1929's crash and ensuing bond defaults.
} 
to precisely the neglected risks (for empirical evidence see Li, Subrahmanyam, and Yang, 2018). As such, we may read sovereign hypothecations as an episode of financial innovation targeted at the neglect of legal risk and at making positive outcomes more salient (Bordalo, Gennaioli, and Shleifer, 2012).

In clear, this interpretation suggests that investors were "gaslighted" by financial intermediaries. This is not a very credible hypothesis as far as sophisticated investors were concerned, as evidenced by the impatient reaction of the judge, and what is more, by the manner in which John Westlake, the counsel for the plaintiffs, cast his case. As we saw, fully aware of where courts would stand, he launched an elaborate kite, that hypothecations amounted to a deed of trust, and looked at whether it would rise (it did not). Nevertheless, what about the general public? We are also skeptical. Although it may appear that the topic was arcane, we find that the general interest press openly discussed it. We already mentioned the swift reaction of the media after the Smith verdict, but one reason why the press reacted so fast was that it was following the subject closely. For instance, in 1868, before the Smith verdict, The Economist ran a leader devoted to a yet another hypothecation contract that offered a pledge of the Italian tobacco monopoly and was comparing its security with respect to other existing arrangements. ${ }^{18}$

If it had not been before, the cat was out of the bag: A British judge had stated clearly and angrily (suggesting impatience) that assuming court enforcement of sovereign hypothecation was delusional, unless a properly constructed deed of trust was set up. The reputable London press with its large readership of retail and institutional investors had chimed in, making sure that everyone would pay attention. Mercurial journals, paid to muddy waters, did not even dare challenge the legal interpretation and instead repeated that Peru had good prospects, which was true. ${ }^{19}$

Against this backdrop, the Smith verdict does provide exceptional testing ground for the hypothesis that hypothecations amounted to a scam meant to create misplaced trust. Either (i) misplaced trust was not key for valuations, the verdict was expected, and nothing should have happened to Peruvian bond prices. Alternatively, (ii) misplaced trust drove valuations and the verdict was unexpected; in this case, the event should have triggered significant selling activity by those gaslighted investors, deluged with reminders and waking up at that point. Under this alternative scenario, bond spreads should have risen.

We collected monthly data on the yield-spread against risk-free British consols for a representative

\footnotetext{
${ }^{18}$ Economist, Oct 10, 1868, p. 1167-8.

${ }^{19}$ The Money Market Review, a paper that had been puffing Peru (see "Peruvian Five Percent Bonds", February 13, 1869, p. 162; "Peruvian Bonds", February 27, 1869, p. 221; "Peru and Her Supply of Guano", February 27, 1869, p. 221; "Peruvian Bonds and the Supply of Guano", March 13, 1869; and "Peruvian five percent bonds", May 1,1869 , p. 451) ran an article on the subject two days after the verdict. The article ended ominously with the promise that it would next seek to discuss "the status of the lender by explaining how far his property, though actually abroad, is technically entitled to the same measure of protection from the British Government as is extended to property at home." ("Foreign loans - Their economic and legal aspects", 29 May 1869, p. 545). The article never came out. The journal's promotion of Peru soon resumed in "Peruvian bonds and the guano trade" (July 3, 1869, p. 7), which staged a faux correspondent who lavished praise on the country rather than on the effects of hypothecations (see also "The Peruvian five percent loan of 1865" (October 23, 1869, p. 381)).
} 
Peruvian guano-bond ${ }^{20}$ and for two synthetic bonds, obtained by computing a weighted and an unweighted portfolio of collateralized bonds. ${ }^{21}$ While the Peruvian spread series serves to test for the May 1869 court decision's direct effect, the synthetic bonds spread series serve to test its indirect effects. Did the verdict affect Peruvian hypothecations and hypothecations at large? To answer these questions we employ the Bai-Perron stability test (Bai and Perron, 1998, 2003), an algorithm that finds the most parsimonious step function to describe a time series. In this framework, if (i) is true, the algorithm should not systematically single-out May 1869 as a significant break date; if (ii) is true, May 1869 should be systematically singled out as a breakdate, and spreads should rise after it. ${ }^{22}$

Figure 1 shows the time-series behavior of spreads for the Peruvian bond and the two synthetic bonds. Dashed lines capture Bai-Perron break dates, and red whiskers represent confidence intervals. The structural breaks thus isolated are coherent with hypothesis (i). ${ }^{23} \mathrm{We}$ can indeed see that May 1869 is a break date only for the unweighted synthetic bond. Yet, in that case, the spread does not spike, it decreases, which is the opposite from what would happen if the verdict had been a wake-up call. Even looking with a fine-toothed comb for price movements in the days and weeks around the decision, one cannot find any change at all. ${ }^{24}$

\section{Collateral as Information Technology}

\section{III.1 Legal Morphology of Sovereign Hypothecations}

If sovereign hypothecations were neither protecting creditors nor gaslighting them, what were they

20 The Peruvian "benchmark" is the guano "secured" $18655 \%$, which had a very active market. We have collected, but do not report the significantly less actively traded $18624.5 \%$, which was seldom quoted and thus provides inferior testing-ground.

${ }^{21}$ In addition to Peru, these portfolios comprise a selection of "Type I" hypothecations, i.e. hypothecations that did not provide any repossession mechanism, as discussed in the next section. The need to ensure diversity and a critical level of liquidity guided our choice. The non-Peruvian bonds are the Chilean 6\% 1867 (custom revenues), Romanian ("Danubian") 7\% 1864 (custom revenues), the Egyptian 7\% 1866 (railways), and the Turkish $6 \% 1862$ (excise on tobacco and salt).

22 The Bai-Perron test is used in Vizcarra (2009) in order to test whether the guano contract enhanced the credibility of the country through the possibility to repossess the collateral (this the author's theory). Examining the period 1830-1878, (Vizcarra, 2009, p.378, Table 5) she finds three (significant at the 95\% confidence level) breaks during the "guano era" (1848-1878): December 1848, November 1870, and December 1875. May 1869 is not one of them. Vizcarra does not discuss the Smith v Weguelin verdict in her paper.

${ }^{23}$ We implement the Bai-Perron procedure employing the R package's routines described in Kleiber et al. (2002) and Zeileis et al. (2003). The algorithm selects intervals in which the time series is approximately stable around a local mean. Each interval we use implies an additional local mean estimate. The algorithm finds a parsimonious description in as much as it trades-off the greater descriptive precision (lower squared errors) achieved by adding an interval, against the cost of adding a parameter. In order to operate the algorithm, we must choose a maximum possible number of steps, i.e. the minimal window of stability. We set this minimal window at one year, but our conclusion does not depend on such choice.

${ }^{24}$ For the $18655 \%$ bond, the single largest weekly price variation during the period going from late April 1869 to mid-June was actually an increase of $2.28 \%$, just after the decision. Peruvian bond prices variations around the Smith v Weguelin decision, calculated with the help of the Economist, are as follows: For the week ending on April 30, +0.16\%; week ending May 7: -2.14\%; week ending May 14: 1.46\%; week ending May 21: 0.64\%; week ending May 28 (the day after decision): 2.28\%; week ending June 4: 0.31\%; week ending June 11: 0.15\%. 
really doing? In this section, we develop our theory inductively, introducing the institutional elements needed to establish our basic contention, that the hypothecations used during the "hypothecation mania" had a purpose and a plan. Our goal is to show that they created infrastructure to foster the provision of information. Collateral clauses supported a reporting system whereby creditors were able to trace the annual flow of money and what is more, recognize in real time delays and diversions. Moreover, the use of collateral clauses over multiple contracts opened the sovereign to cross-scrutiny, as repledging was a tangible signal that no new revenue source could be documented, thus new debt was piling up on the same fiscal capacity. To articulate this argument, we need first to delve more closely into the precise design of individual sovereign hypothecations and analyze their legal morphology.

To that end, we assembled a complete library of bonds' prospectuses, corresponding to the universe of London stock exchange issues. We constructed it based on the list of sovereign bond issues in Council of Foreign Bondholders (1878), using a primary source, the archive of the London stock exchange, to clean up the list and pin down the precise date of issue (month and day) for each bond. With this information at hand, we mined online newspaper repositories to retrieve prospectuses. ${ }^{25}$ When published prospectuses in the media were incomplete, or were only summarized by a journalist, or missing, we turned to other primary or secondary sources such as the archive of the London stock exchange, the archive of private banks (Rothschild), or contemporary investor handbooks (such as Fenn, 1855). We then went over each loan individually, and when they involved unusual features, whether legal or other, we performed additional investigation. Indeed, a difficulty of figuring out the meaning of hypothecations is the circularity of the task. It is hard to figure out the meaning of individual clauses without the relevant legal knowledge, but on the other hand, what is relevant legal knowledge depends on the clauses drafted in contracts.

This was a laborious work but a very informative one too, because it led us to realize that the clauses had not been introduced at random, and to start grasping the financial and legal logic at work. To begin, we noted that the general manner in which sovereign hypothecations were "performed" consisted of a formula whereby the sovereign did "bind" herself, or "pledge to hypothecate" a designated asset or set of assets as security for the due payment of the interest and amortization of the loan. In addition, it was standard to pledge the "general credit" of the country. We understand this further pledge as recognition of the borrower's liability over and beyond the specific hypothecation provided. The prospectus then recited the characteristics of the hypothecation, stating its nature and location. Hypothecated assets were typically physical or else they were a fiscal revenue. As we shall discuss in detail later on, the items pledged included custom

25 Two newspaper repositories we employed are the British Newspaper Archive, at www.britishnewspaperarchive.co.uk and The Times Digital Archive, at www.gale.com. The prospectus (or the general bond), rather than the debt contract, is the relevant document. At the time, the debt contract involved the underwriter and the issuer and stipulated such things as the conditions of issue, the price, the fee and the amount of the loan underwritten. By contrast, the prospectus described the obligations of the borrower vis-á-vis the bondholders or investors and as a result, it documented the hypothecations. 
revenues, lands, wood from forests, railways, and export commodities such as guano. Immovable hypothecations vastly surpassed movable ones in numbers. If the point of hypothecation had been for lenders to secure themselves by receiving contingent control of a movable security à la Calomiris et al. (2017), then the observed hypothecation tactics do not make any sense.

As the case of guano underscores, even in the case of pledges involving export goods, all that might have been grabbed was the marginal production, the revenue from sale. The guano reserve was almost never directly pledged. Then, as already said, even after grabbing it, the judge in London would have seen to it that it be returned to its legitimate owner. We could identify two alternative hypothecation regimes. The "boilerplate", the focus of this paper, was a regime we call Type I, by far the most widespread: 56 individual contracts, in a population of 68 hypothecations and 117 contracts, come under this heading. As we found, Type I hypothecations did not involve at all any effort or semblance of effort to create a secure system to hold and manage the asset. Instead, they thoroughly documented the earning capacity of the source, along with the value of the asset. Simultaneously, the prospectus documented the value of the loan and/or the annual burden (interest and amortization). From the language of the document, it appears that a high cover was expected to "secure" the investor better, but the security was virtual. At no point was the asset itself surrendered. In the case of guano for instance, the contract made clear that it remained an inalienable property of the Peruvian government. Revenues were collected by the civil servants, agents or employees of the borrower (custom officers, for instance). No mechanism was put together either to appropriate the collateral in case of non-performance.

Instead, what we found was that the prospectus of Type I hypothecations described a sophisticated technology to supervise the transfer of annual or semi-annual dividends to creditors out of the source pledged as long as the loan would perform. They tasked an agency with ensuring that things would work as planned and to report to creditors. British consuls were often involved because they provided a trustworthy third party, at the same time their private attributions ensured that they could be remunerated for their work out of the proceeds of the loan. What is more, their molesting by local authorities amounted to a casus belli and created a right for Britain to intervene. There is evidence in contemporary commentary that the involvement of such personnel was sought for the manner in which the arrangement secured the transfer of funds to pay the interest, from the minute it had been transferred to the representatives of the creditors. In other cases, prestigious banking firms with agents abroad played this supervisory role, or special purpose arrangements were created that spoke of "trustees", but again their attributions were limited to the transfer of dividend funds alone.

In other words, Type I hypothecations were not about securing the creditor in the sense understood in modern theories of collateralization. Rather, they sought to identify credibly a government source of income and to render more transparent and secure the annual transfer of funds. Consider for instance the Imperial Moorish Loan, issued in 1862 in the name of Sultan Muhammad IV. The prospectus provided for the hypothecation of half of the custom revenues $(£ 160,000$ out of $£ 320,000)$, out of which the annual interest and amortization $(£ 38,000)$ would be serviced (art.5 \& 
6). It resulted from this that ample "security" was provided. British government appointed "Special Commissioners" to receive from Moroccan officials the custom duties so hypothecated as they came due (art. 2). Each semester, no later than six weeks before the coupons came due, the Commissioners would transfer the money to the agents in Morocco of the London banking firm in charge of servicing the loan (Robinson, Fleming), to pay creditors on the due date (art. 3). The involvement of the British government did not imply at all a British guarantee, as article 4 stated very clearly. ${ }^{26}$ The point, instead, was to improve the security of the transfer. Once the money had been paid over by the Moroccans to the Commissioners there was no going back. Reflecting the same logic, the prospectus stated that the reliability of the estimates regarding Moroccan custom revenues was "certified" by the British consul in Morocco (art.5).

There was significant legal ingenuity involved and as a result institutional variance in the details from loan to loan, but not enough to discern differentiated patterns. The general logic remained the same overall. The guano loans, another Type I hypothecation, can be cast against this same backdrop: The London merchant banks involved were not pledging their credit on the fact that the debts would be repaid (we saw they were agents). They were tasked with documenting guano extraction and certifying the extent of the resources. As we saw, that they were agents for Peru meant that they did not get to decide what to do with the guano. However, they were expected to report to investors. This was significantly more transparent than if the government had simply collected the guano itself and sold it on the market. Type I hypothecation used reputation capital to do just this: keep people abreast in an orderly way. At any point in time, investors did know where guano was held and what its prospects were. Nevertheless, that did not mean they could get their hands on it. In this sense, contemporary commentary that the hypothecation operated "independent of the Peruvian government", as was declared in 1849 was perfectly correct, though it has been misconstrued in modern research as "owned independently of the government", which it was not. ${ }^{27}$ The goal was to provide clean information - in the sense of an improvement in the quality of signals. This has been mixed up with a question of ownership, on which the hypothecation had no bearing. The sovereign collateral "boilerplate" clause was meant to create a credible reporting system whereby creditors were enabled to trace the flow of money and in particular, recognize delays and diversions. This is not comparable at all to what is done with modern CSDs.

The previous conclusion that sovereign hypothecations were not just a failure to collateralize properly comes out strongly from examining twelve contracts, counting borderline cases, which we group as "Type II". Type II hypothecations are interesting to investigate because they illustrate that the modern concept of "securing" the lender through genuinely executable collateral was fully understood at the time and could be mobilized in practice if need be. Contemporaries were familiar with the trusteeship logic. In a few cases, they sought to harness it to design more capacious

\footnotetext{
26 "Her Majesty's Government is not liable for the payment of a larger sum of money than which [the Commissioners] receive".

${ }^{27}$ London Daily News, January 5, 1849
} 
contracts (from the vantage point of repossession and protection of the lender against information asymmetries). In practice, individual Type II hypothecations were different from one another. Still, all sought to create a tangible right for creditors, giving them recourse in case of non-performance and, in particular, control over the pledge, whether direct or indirect. We will explore and discuss every single such bond in the dedicated Appendix. Here we report on the underlying logic, which relied on two foremost mechanisms approximating a CSD arrangement. First, there was the option of turning the sovereign into a private entity. If a mortgage statute was available in the country, stakeholders could achieve this through a deed of trust (which British courts would recognize) by formally registering the mortgage. Otherwise, the sovereign could borrow through a private vehicle, which could be sued. Finally, stakeholders could ask for the rulers' personal property as collateral if lending to a feudal ruler, such as the Khedive of Egypt. Second, the loan could leverage aspects of international law that could make the sovereign liable for the payments to other sovereigns. In this way, another sovereign entity stepped in, which could ask redress in the name of the creditors.

The Spanish Quicksilver loan of 1870 offers an example of Type II. This loan pledged the revenue of Spain's Almaden mercury mines. In this case, the agent for the bondholders (the House of Rothschild) was in charge of directly operating the mines, selling the mercury abroad and paying the bondholders semi-annually from the sale proceeds. The loan provided for a mortgage deed under the Spanish mortgage law of 1860, with the mines, machinery, buildings and works formally designated as security. In case of non-performance by the sovereign, Rothschild, the creditors' agent, had the right to seize the property. Of course, questions remain on the extent to which creditors could have achieved this in practice since the sovereign might have leaned on Spanish courts. Was the power of the House of Rothschild or the rule of law that conferred value to the Almaden hypothecation? The fact was that the Quicksilver Loan traded at a premium and a subsequent default spared it, consistently with the notion that Type II hypothecations were different. $^{28}$

\section{2 Theory and Predictions}

The hypothesis we put forward and test in subsequent sections proceeds inductively from our analysis of the nature of hypothecations and deductively from the theoretical references mentioned in the introduction. Partisans of the scam theory, such as Coleman, suggest that delinquent sovereigns packed in the hypothecation corner of the market to exploit investors better. Instead, we suggest that hypothecations were not necessarily fraudulent, as they promoted market access and financial inclusion. However, unlike studies stressing enforcement, we do not claim that hypothecations did mitigate risk in case of sovereign default. Instead, we claim they were an information production mechanism, which also eased monitoring. Hypothecation clauses

\footnotetext{
${ }^{28}$ See Martín (1980); López-Morell (2016). A contemporary discussion of the mortgage law of 1860 is Pantoja and Lloret (1861); the application decree is in Ministerio de Gracia y Justicia (1861). Compare our interpretation with Chabot and Santarosa (2017, p.32), who suggests that the hypothecation worked through the "legal difficulties selling quicksilver abroad." Because of Smith v Weguelin, however, this could not be the case.
} 
disclosed information on sovereign resources and, mapping the repayment process in detail, created "reference points" around which engaging the sovereign became possible. ${ }^{29}$

Consider, for instance, the case of the Moroccan loan above. The prospectus stipulated an obligation to transfer funds from the Commissioners to the banker's agents in Morocco at least six weeks before the coupons were due. If this did not happen, it meant that the Commissioners had not received the funds, creating grounds for questions and investigations by creditors and their agents. Authorities might decline to answer, but that would be information. Without the technology, no such information would be forthcoming. The credit event might even have gone unnoticed because, for instance, the banker might have paid out the interest himself. In other words, Type I hypothecations did reduce the scope for hidden action, providing detailed workouts that multiplied occasions to observe the borrower's behavior, helping to update beliefs, identify deviations and curb moral hazard. The consequence of this is that collateral was valuable. We predict that Type I bonds traded at a premium (higher price) compared to otherwise similar nonhypothecated bonds, helping reduce debt costs for riskier sovereigns. ${ }^{30}$

If non-enforceable hypothecations eased asymmetric information through disclosure, they ought to have substituted for other forms of information. One would expect to see collateral used particularly intensively in countries that had poor informational infrastructure. At the time, standard macroeconomic parameters were not published for many borrowers or were of poor quality. For instance, they were rarely updated, sometimes deliberately, resulting from fragmented polities and insufficient administrative resources. The lack of data can still be a problem today, albeit admittedly to a lesser extent, though the Greek crisis and other episodes offer a counterexample. ${ }^{31}$ Against such a backdrop, we suggest that collateralization offered a solution for market access that was particularly valuable for countries with a bad data record. We do this by using data from The Statesman's Yearbook, a popular contemporary handbook mentioned by

\footnotetext{
${ }^{29}$ This squares with the theoretical interpretation of the functions of contracts when coercive enforcement is not the principal goal. Hart and Moore (2008) describe contracts as "reference points" and analyze the role of contractual stipulations in the management of behavioral expectation in a bilateral relationship. Here, instead, we focus on their role in distributed monitoring among rational agents.

${ }^{30}$ This is an ex-post channel, reducing moral hazard after the loan is granted. It runs parallel to standard theories of collateral where risky borrowers post collateral, collateral enforcement increases the cost of default, thus committing the borrowers to take steps that increase repayment chances (see Boot, Thakor and Udell, 1991; Boot and Thakor, 1994; Aghion and Bolton, 1997; Holmström and Tirole, 1997). The main difference is that this is achieved not through collateral repossession, but through and increase in the likelihood of being caught if actions decreasing the chances of repayment are undertaken.

${ }^{31}$ On 01/08/2010, the European Commission (2010, p.3) report documented how "the Greek government deficit for 2008 was revised from 5.0\% of GDP (the ratio reported by Greece, and published and validated by Eurostat in April 2009) to 7.7\% of GDP. At the same time, the Greek authorities also revised the planned deficit ratio for 2009 from 3.7\% of GDP (the figure reported in spring) to 12.5\% of GDP”. Such large revisions were tightly linked to the loss of confidence in Greek debt, which marked the beginning of the European debt crisis. Similar problems are even larger for developing and emerging sovereigns. For example, Jerven (2013) documents how data limitations constrain our understanding of the debt and growth conditions of African nations. It is interesting to note, thus, how more than half the 132 billion lending from China to African states came under the form of collateralized loans (Bräutigam and Gallagher, 2014). On the historical development of methods and numbers to assess debt sustainability, see instead Flandreau, (2003) and Flandreau and Zumer, (2004).
} 
leading stock market operators as a critical source to document fiscal records. As we show, countries most likely to collateralize were countries for which public information was of poor quality. In other words, hypothecation, even if non-enforceable, was valuable in unlocking capital markets. ${ }^{32}$

To deepen the role of hypothecations in limiting asymmetric information, we propose another test investigating the role of underwriters on the decision to hypothecate. Chemmanur and Fulghieri (1994) argues that underwriters can act as certifiers for new borrowers. Flandreau and Flores (2009) documents how bank reputation played precisely this role in the 1820s sovereign bond market. The argument is that prestigious banks rendered sovereign debt information insensitive because prestigious underwriters signaled good borrowers (Gorton, 2017). As a result, investors had only to worry about the reputation of the underwriter. If hypothecation constituted an information technology, we should observe a relationship of substitutability between them and prestigious underwriting too. The reason is that fiscally opaque borrowers perceived by prestigious underwriters as sound were under no pressure to collateralize.

Finally, our comparison of hypothecation in sovereign debt with an information system brings a natural parallel with Veldkamp (2006)'s emphasis on the relation between media frenzies and asset prices. A consequence of the system created by non-enforceable hypothecation is the enthusiasm it spurred for new borrowers and its vulnerability to an information panic of a peculiar kind. Such panic materialized in 1872 when The Economist came out against a loan project pledging the revenues expected from a state-run navigation and railway behemoth. The transportation network planned would run through Honduras, enabled ships to move across the Isthmus, and required large sums. The calculation of the "security" rested on the traffic the railway would supposedly capture, diverting trade going through Cape Horn. As it turned out, the trade numbers had been doctored. Several media and powerful creditor agencies took up the cudgel against the railway loan, provoking a confidence crisis.

This event and the legal reaction that ensued is another occasion to test our mechanism. We show that the risk was not fooling investors into believing that they could repossess the collateral when they could not. Instead, the risk was the manipulation of the information in the prospectuses. We argue that this is precisely what invited the participation of lawyers in the drafting of hypothecation contracts, not to assist with fraud but to help increase the reliability of the disclosure process (uphold high-quality disclosure). By studying which behavior was criminalized after the Honduras crisis, we can confirm that the general concern was indeed manipulation, and by consequence, information transmission was the key service delivered through collateral clauses.

\footnotetext{
32 This is an ex-ante channel, reducing asymmetric information at the loan-granting moment. It runs parallel to standard theories of collateral where borrowers that have the quality/resources to repay the loan use collateral as a costly signal (see Bester, 1985, 1987; Besanko and Thakor, 1987a, 1987b; Chan and Thakor, 1987; Boot et al., 1991). Only, the pledge here is credible not due to collateral enforcement, but to the involvement of experts (lawyers, bankers, scientists - se Flandreau, 2016) in quantifying revenues pledged, and to the verifiability of such pledges by independent experts at any point.
} 


\section{Data}

To perform the tests described above, we need three elements:

1. Data on prospectuses characteristics. At the least, we need complete information on collateral clauses and their nature and bond maturity to calculate yields.

2. Price data at the panel level, to assess how investors' valued different contract features after considering sovereign-specific risk.

3. Information on fiscal transparency at the sovereign level to understand whether hypothecations indeed catered to investors' demand for information.

To this purpose, we assemble novel data on sovereign debt characteristics, secondary market prices and sovereign fiscal transparency.

\section{IV.1 The Library of Bond Prospectuses}

To obtain information on bond characteristics we hand-collected a comprehensive library of prospectuses for 117 sovereign bonds issued by thirty-two sovereign entities between 1849 and $1875 .{ }^{33}$ Such a library amounts to a novel and thorough database for the entire population of hypothecations and almost the whole population of bonds issued in London during the mid-19th century foreign debt boom. ${ }^{34}$

The bar chart in Figure 2 shows the evolution of such foreign debt boom, with about $80 \%$ of the bonds issued during the thirteen years between 1862 and 1875. Sixty-eight of the 117 bonds include collateral clauses in their prospectuses, with only two years (1860 and 1874) seeing no hypothecation floated. This large number is per se evidence of the importance of hypothecations in the 19th-century sovereign debt market.

The prospectuses library covers an almost equal number of non-hypothecated bonds and sovereign hypothecations (Table 1). As previously introduced, we divide the hypothecated bonds in Type I and Type II based on whether the prospectus arranged for means of bondholder recourse in the case of sovereign default. As expected, the three groups show different financial characteristics. Non-hypothecated bonds are larger deals than hypothecated ones (nine million pounds on average against five), involve either Baring or Rothschild as underwriter almost half the times, have longer maturities, ${ }^{35}$ and, unsurprisingly involve lower yield at issuance. While hypothecations rarely

\footnotetext{
${ }^{33}$ In particular, twenty-two among the thirty-two sovereign entities covered are accountable for ninety-two of the 116 bonds. The Ottoman and Russian Empires are the most represented issuers, respectively accounting for twelve and thirteen bonds. Egypt instead issued nine bonds, while Chile, Brazil and Argentina seven.

${ }^{34}$ Among the bonds with consistent trades recorded in the Course of Exchange, we omit only four: Italy 1861 5\% rentes; Mexican 1851; Mexican 1864; Turkish 1865 6\%. The Italian bond was issued in Paris; the British press does not document the prospectus. For the other three bonds, we could not find complete enough prospectus information in 19th-century newspapers.

35 Missing maturity bonds are perpetuities. No such bond includes collateral clauses. Perpetuities were the standard way to borrow for established sovereigns. In our dataset, we unsurprisingly find that only European nations issued such securities. Such bonds are Belgium 1874; Denmark 1863; France 1871 and 1872; Italy 1863; Portugal 1862, 1863, 1867 and 1869; Spain 1869, 1871 and 1872.
} 
involved prestigious underwriters, enforceable ones involve Baring and Rothschild relatively more often, highlighting the different nature of such deals.

In Figure 3, we introduce prospectuses' details for the sixty-eight hypothecated bonds. In the bar chart on the left, we summarize the assets hypothecated. At the same time, on the right, we split the sample over the details of the pledge. Concerning assets pledged, we notice that the most common objects of hypothecation were revenue streams. All except eight Type I hypothecations earmark specific revenues. When the pledge centers on non-revenue items, these are often some easy to monitor and revenue-generating immovable assets (e.g. railways). Only six bonds pledged movable assets. Such lack of movable assets pledged, as already emphasized, is at odds with repossession upon default if this had been the plan.

On top and above pinpointing assets, pledges provided a precise quantification of the proportion between the value of the pledge and the debt it "covered". In the bar chart on the right, we observe that this feature was common for Type I and Type II hypothecations. The underlying logic mobilized in each case was different, however. Prospectuses for Type I hypothecations were more concerned with monitoring. Thirty out of the fifty-six Type I bonds tasked bondholder representatives with specific monitoring duties and supervision of the payment process. Some bonds even specified additional benchmarks, such as deadlines for money transfers (as we saw when we discussed the Moroccan example) or milestones for completing the underlying project. 36 The result was the continuous production of information regarding fiscal performance. Of course, as said, such provisions were not enforceable in court either. However, they still provided tripwires that could help interested investors in monitoring the borrowing sovereign. By contrast, as can be seen, Type II hypothecations included such mechanisms to a much smaller extent. As Type II did envision repossession, they tended to work more like a "traditional" collateral, where security substitutes for information gathering. Type I "boilerplate" peculiarity and its affinity with information production emerges as particularly evident from this comparison.

The panel of yields: To understand how investors valued hypothecations, we build a panel of yields. We collect information on bond prices at the closure of the year ${ }^{37}$ from 1864 to 1875 from The Course of Exchange, the official price list of the London stock exchange. The Course of Exchange reporting system was scrutinized by brokers, who could challenge prices that they found off the mark, making the source reliable. We compute each bond's yield-to-maturity based on the price information we compile and the amortization profile we collected from the prospectuses.

The yield dataset achieves comprehensive coverage of the original cross-section of bonds, for 766

\footnotetext{
${ }^{36}$ The Ottoman 1869 bond prospectus provided that "each half-year, at least one month before the maturity of each semiannual payment of interest and redemption, the contractors may be in possession in Paris of the requisite funds for such payment". The Honduras 1870 bond prospectus mandated that the first tract of the Railway project financed should have been "finished next November. Messrs. Waring Brothers and McCandlish have undertaken, under heavy penalty, to complete the second section at the end of 1871"

${ }^{37}$ We collect the last available price for December. We do not collect price information unless we observe at least one posted price during December. Bonds that do not trade for an entire month are likely to be illiquid and display noisy price behavior (see Chavaz and Flandreau, 2017).
} 
yield entries. We have at least one yield observation for 106 bonds or $92 \%$ of the bonds in the cross-sectional dataset. The coverage is also good over sovereigns. In that sense, we note that we observe at least two yield realizations for almost all the issuers' bonds (exceptions are the Danube Company and Germany's bonds). Most important, nine of the most important bond issuers in our dataset both issued bonds with different hypothecation statuses and have multiple yield observations in the panel, allowing us to conduct a within-sovereign analysis of collateral clauses. $^{38}$

\section{IV.2 New Measures of Fiscal Transparency}

A key contribution of this paper is to show that collateral clauses were especially employed in poor information environments. To achieve this, we need to document borrower's information availability and, in particular, fiscal transparency. To do this in an economically meaningful fashion, we need to place ourselves in the specific informational context contemporary century investors confronted. Flandreau (2003) and Flandreau and Zumer (2004) discuss the rise of systematic, comparable fiscal data in the 19th century and show it was a late phenomenon. It was not until the last two decades of the century that comparable fiscal indicators became available. The initiative came from investors and prominent financial institutions who drew on the work of statisticians or built their own observatories. Before this, sources remained scattered, and investors had to navigate fragmentary documentation. Against this backdrop, a revolution was the Statesman Yearbook. ${ }^{39}$ Because of its unique and convenient character and its reputation as a source for accurate and up-to-date information, it rapidly acquired a solid reputation. In particular, it stood in very high regard in financial circles. Lionel Louis Cohen, a leading stock exchange market maker in foreign bonds, describes it as the standard source for macro-financial data in the mid-1870s (Cohen, 1876). ${ }^{40}$

The Statesman's editor, Frederick Martin, worked by using official national sources. When they were missing or not up to date, he approached individual foreign governments directly through their embassies. Martin's ultimate goal was to report such information as it stood for the current year. He was aware of possible problems with his sources but did not try to make adjustments. The Yearbook covered country-level material, aiming at a comprehensive picture of each country's political and economic position. In particular, it documented the political regime, demographic data, exchange rates, and, most importantly, fiscal numbers. Fiscal numbers included debts, budgets, and executed accounts. That no such source as the Yearbook existed before 1864 speaks volumes of the hurdles that laid in the way of information gathering. Often, countries did not have (and continued not to have) relevant fiscal data or refused to release it. Some countries that borrowed in the London stock exchange had incomplete public finance data only, or none. As a

\footnotetext{
${ }^{38}$ Italy, Turkey, Egypt, Chile, Argentina, Sweden, Hungary, Denmark and Costa Rica, account for 59 bonds in the prospectus' library.

${ }^{39}$ Frederick Martin, a Swiss immigrant in Britain (Steinberg, 1966), had launched it. Martin started the Yearbook in 1864, following previous failed attempts such as Horn (1859), which lapsed after a few years only.

${ }^{40}$ As a result, the Statesman Yearbook has already been used in previous historical data reconstructions focused on government debt and revenue (Flandreau, Cacheux, and Zumer, 1998; Flandreau and Zumer, 2004).
} 
result, we will exploit the Yearbook as a means to measure the quality of the information publicly available for any given country in any given year and, in particular, document fiscal opacity. To do so, we focus on the availability and frequency of update of information on each sovereign's revenue, the best proxy available at the time for capacity to service sovereign debt. ${ }^{41}$

Consider Yearbook volume published in year $x$, containing revenue information from sovereign $c$ on budget-year $y$. The first variable we construct is a dummy $A(c, x, y)$ :

$$
A(c, x, y)= \begin{cases}1 & \text { if } x-y \leq 2 \\ 0 & \text { if } x-y>2\end{cases}
$$

which captures whether volume $x$ contained recent (less than two years old) revenue information about sovereign $c .{ }^{42}$ Then, consider the revenue information contained in volume $x$ regarding sovereign $c, I(c, x)$, regardless of its age. Was such information at least updated since the last Yearbook volume? Answering such question, we build the $B(c, x, y)$ dummy:

$$
B(c, x, y)= \begin{cases}1 & \text { if, in volume } y, I(c, x) \neq I(c, x-1) \\ 0 & \text { if, in volume } y, I(c, x)=I(c, x-1)\end{cases}
$$

which records whether $c$ 's revenue numbers in volume $x$ differed from c's revenue numbers in volume $x-1$. Variable $A$ captures a static notion of information availability, variable $B$ the dynamic one of increase in information availability. Finally, we record the $x-y$ difference as a more nuanced proxy of information quality, summarizing how old the information contained in each volume $x$ regarding each $c$.

\section{An Empirical Assessment of Sovereign Collateral}

\section{V.1 Did Bond-holders Care about Hypothecations?}

We established that it is difficult to believe recourse upon default was the main driver of sovereign hypothecations popularity. This begs the question of whether Type I hypothecations were considered as valuable at all by investors. To answer such questions we will employ simple yield regressions. Our specification builds on works investigating contemporary government bonds

\footnotetext{
${ }^{41}$ Alternatively, we may have also considered the presence of debt information and/or demographics as relevant information. Debt data though, is ambivalent. On the one hand, it conveys the extent of sovereign fiscal obligations. On the other hand, it is to an extent correlated to public investment and growth. As such, more debt information may not mean more information. Demographics, particularly population numbers, partly determine the sovereign's fiscal base. At the same time, population data without revenue data means that there is still complete uncertainty on how much the sovereign can extract from each of her citizens. We thus believe that a focus on revenue is a better choice. Moreover, many Yearbook volumes tried to distinguish between budget estimates and realized fiscal numbers. A budget estimate is a projection presented to the body tasked with ultimately releasing the country's budgetary planning (often the Parliament). A realized fiscal number is an expost figure documenting effective tax collection. In practice, such distinction is often blurred; we thus decide not to consider it.

${ }^{42}$ No result depends on the two years old threshold, as we show in the Robustness Section.
} 
(Butler, Fauver, and Mortal, 2009; Novy-Marx and Rauh, 2012; Gao, Lee, and Murphy, 2019, e.g.). The equation is:

$$
\text { Yield }_{b c y t}=\alpha+\eta_{t}+\beta \text { Collateral.bcy }_{.}+\Gamma X_{b c y t}+\epsilon_{b c y t}
$$

where Yield bcyt $_{\text {is }}$ the yield-spread over British consols, recorded in year $t$ for the bond $b$ issued by sovereign $c$ in year $y .{ }^{43}$ The primary independent variable, Collateral.bcy, is a dummy variable taking value one if the bond includes collateral clauses (Type I and II) and zero otherwise. $\eta_{t}$ is a vector of year fixed effects to control for aggregate, time-varying confounders. $X_{b c y t}$ is a matrix of covariates including at its largest the log of the total issue size to control for liquidity (e.g. Gao, Lee, and Murphy,2019); the log of maturity to control for the ex-ante risk born by the bondholders; dummies for the presence of an explicit project purpose on the bond's prospect; for the prestige of the underwriter ${ }^{44}$; for singling out perpetual bonds; ${ }^{45}$ for partialling the role of Type II clauses out. Finally, $\boldsymbol{\varepsilon}_{b c y t}$ is the standard error, clustered at the $c y$ country-issue vintage level to account for different tranches of the same loan, issued at the same time but traded and priced separately.

We estimate Specification 1 first pooled across sovereigns, and then adding sovereign fixed effects. We proceed and repeat such estimation, including a Type II dummy among the controls, to understand which role arguably enforceable clauses played in sovereign hypothecations premium. As emerging countries collateralized their bonds more often, controlling for country risk is crucial to elicit hypothecation's effect on the cost of debt. Showing both pooled and within estimates is important, too, as the difference between the two coefficients informs us on selection into hypothecation.

We present the results in Table 2. In the first panel, we can see how bondholders required a 2.5\% higher spread to hold hypothecated bonds after accounting for bond characteristics but not for country risk. The same bondholders, though, required about $1 \%$ lower spreads to hold a hypothecated bond after accounting for country risk (Within panel). ${ }^{46}$ Inclusion of a Type II

\footnotetext{
${ }^{43}$ We source British consols' yields from the December column of Klovland (1994) Appendix Table 1.

44 This particular dummy equals one for bonds underwritten by Baring and Rothschilds, the leading banks operating in the fixed income market at the time.

${ }^{45}$ To include maturity as control while at the same time not losing valuable information on the non-hypothecated yields of Belgium, Denmark, Italy, Spain and Portugal, we substitute the missing maturity of perpetuities with an arbitrary number higher than the highest maturity recorded. Simultaneously, for such a choice not to "pollute" other estimates, we always include a perpetuity dummy to account for perpetuity-specific characteristics.

${ }^{46}$ Estimating the equation with country fixed effect implies using only the variation from countries that floated both hypothecated and non-hypothecated bonds. If, in such a subset of sovereigns, the safer ones issued bonds with collateral clauses, we could not conclude that demand for hypothecated bonds was higher when considering country risk. We show in Table 6 that this is not the case by estimating Equation 1 again within and pooled only for sovereigns floating both hypothecated and non-hypothecated bonds. From the result of such estimation, we observe that the relationship between Type I hypothecations and yields turns negative and statistically significant only with the inclusion of country fixed effects.
} 
dummy only decreases the within-sovereign premium by a few basis points. ${ }^{47}$ Finally, Type II bonds commanded a further premium between $2 \%$ and $1.3 \%$ and this, instead, independently of accounting or not for country risk.

In previous Sections, we have shown that yields' reaction to a Court ruling clarifying that sovereign collateral could not be repossessed are not in line with theories of naive investors fooled by hypothecations. Here, we bring evidence that these same investors appreciated hypothecation clauses even when they did not increase recourse chances upon sovereign default. Thus, Type I hypothecations constituted a valuable tool for risky sovereigns trying to gain market access at better terms.

\section{V.2 Information and Collateral}

In the previous Sections, we assessed evidence against enforcement being the main driver of the extensive use of collateral clauses in sovereign debt. Theories of collateralized debt stress enforcement as the channel through which collateral limits asymmetric information and curbs moral hazard. Studying the prospectuses, we highlighted a different possible channel. Collateralization disclosed certified information on sovereign revenues and set up a structure to better monitor the sovereign. Certified information disclosure should lessen information asymmetries, and easier monitoring should limit the scope for hidden actions. If this is the case, we should expect that the "classic" substitution between collateralization, information disclosure and monitoring technologies (see, e.g. Berger et al., 2011 and Berger, Frame and Ioannidou, 2011) still stands. Usually, collateral is an alternative to more information and more monitoring. Here, another possible information production and monitoring mechanism.

To investigate this hypothesis, we study the correlation between collateralization and other available information and monitoring technologies, i.e. disclosure of official figures and arranging with the most reputable banks. We start comparing the rate at which the Statesman Yearbook reported updated revenue figures for each sovereign. Consider the chapter covering sovereign $c$ in the Yearbook volume published in year $y$. An ideal transparency benchmark would be a sovereign releasing an accurate budget with revenue estimates for the current year, every year. Plotting on the $y$-axis the year of the most recent budget estimate reported and on the $x$-axis the year of the Yearbook edition, such a benchmark would constitute a 45-degree line in the space, starting with the Yearbook's first volume in 1864. Any delay in releasing figures would distance a sovereign from the 45-degree full transparency. The further to the right the update-line of sovereign $c$, the less transparent the sovereign. In Figure 4, we plot update lines for each country, showing red countries that do issue hypothecations and blue countries that do not. We can appreciate how the average sovereign lags its non-hypothecating counterpart by about one year and a half, with just a slight catch-up towards the end of our sample. ${ }^{48}$

\footnotetext{
${ }^{47}$ We show in Figure 7 that such a result is robust to multiple marginal changes to the Type II definition.

${ }^{48} \mathrm{We}$ also observe that hypothecating sovereigns have a much higher variance of updates. Indeed, among these, we also see a few quite transparent states, i.e. Italy, Denmark and Hungary. These examples are not against our
} 
To check the robustness of this correlation, we will estimate the linear relationship between three proxies of transparency and the issuance of hypothecated bonds. We will address two critical confounders. First, it may be that sovereigns that tap the market more often are both more likely to issue hypothecated bonds and less transparent. Thus, what we observe in Figure 4 would be a feature of a broader relationship between lack of transparency and greater need for credit. Second, less transparent sovereigns are likely to be riskier overall. If what we observe was to be explained away when controlling for country risk, this would be evidence against our information mechanism.

To mitigate these concerns, we estimate the following linear relationship:

$$
\begin{aligned}
& \text { Last issuance Type } \mathrm{I}_{c y}=\alpha+\beta \text { Information }_{c y}+ \\
& +\gamma \text { Recent issuance }_{c y}+\delta \operatorname{Risk}_{c y}+\epsilon_{c y}
\end{aligned}
$$

where the dependent variable, Last issuance Type $\mathrm{I}_{c y}$, is a dummy equal to one if sovereign $c$ 's last bond issued up to year $y$ is a Type I hypothecation. Information In $_{c}$ is one of three proxies for transparency. First, the $A(c, x, y)$ dummy taking value one if the revenue information for sovereign $c$ reported in Yearbook volume $y$ is less than two years old. Second, the $B(c, x, y)$ dummy taking value one if revenue information for sovereign $c$ in Yearbook volume $y$ is different from the same sovereign's entry in volume $y-1$. Third, the discrete variable recording how old is revenue information published in volume $y$ of the Yearbook regarding each sovereign $c$. Concerning further controls, Recent issuance ${ }_{c y}$ is a dummy taking value one if the sovereign $c$ issued any bond in years $y-1$ and $y$, checking whether recent bond issuance per se, not only the use of Type I hypothecation, is correlated with low transparency. Finally, the variable Risk cy $_{c y}$ is one of two country-risk proxies. First, the lag of the volume-weighted yield for sovereign $c$ computed using our yield panel, which proxies risk with its perception in the London Stock Exchange. Second, the country's lag GDP per capita in 2011\$, assembled by the Maddison Project (Bolt and van Zanden, 2020), proxies risk with a measure of country resources.

Overall, Table 3 depicts a strong negative relationship between transparency and the use of Type I hypothecations. We present over the columns a crude correlation without controls (column 1); one conditional on the Recent issuance $c y$ variable (column 2); one conditional on the Recent issuance $_{c y}$ variable, and each of the Risk sy $_{c y}$ proxies, lag volume-weighted yield (column 3), lag GDP per capita (column 4) and both of them together (column 5). No matter the specification, we find a 20 to 30 percent negative correlation between the presence of recent or updated information and the dummy tracking whether the sovereign last tapped the market with a Type I bond. Moreover, an additional one-year lag in the information disclosed correlates with a 5 to 14 percent greater

reasoning, however. Italy and Hungary were somewhat new political entities. Instead, Denmark lost in 1864 one quarter of its landmass to the German Confederation. It is thus reasonable to believe that their fiscal information, though timely, was discounted, placing them in the necessity to tap other means of certification for their balance sheets. Overall, the reliance of new states on hypothecation is in line with Diamond (1989), stressing the role of reputation in mitigating information asymmetries (and, conversely, the importance of alternatives to a reputation for non-established borrowers). 
likelihood of tapping the market with a Type I bond.

Finally, we leverage the fact that an alternative certification technology existed, i.e. dealing with market leaders in the underwriting business when arranging the debt. Fixing the level of fiscal information scarcity, an established relationship with a reputable underwriter signals better quality (Chemmanur and Fulghieri, 1994; Flandreau and Flores, 2009; Gorton, 2017) and should allow the opaque sovereign to rely less on Type I hypothecations. Armed with our proxies of fiscal transparency, we can test whether this substitutability relation holds estimating:

$$
\begin{aligned}
& \text { Last issuance Type } \mathrm{I}_{c y}=\alpha+\beta \text { Recent prestigious issuance }{ }_{c y}+ \\
& +\omega \text { Information }_{c y}+\gamma \text { Recent }_{\text {issuance }} y+\delta \text { Risk }_{c y}+\epsilon_{c y}
\end{aligned}
$$

Here, our independent variable of interest is Recent prestigious issuance ${ }_{c y}$, a dummy taking value one if $c$ issued bonds with Rothschild or Baring in the last two years. Information $c y$, included as a control, ensures that we compare countries with similar fiscal opacity levels. Other controls do not vary. Table 4 shows a robust negative relationship (substitutability) between recent relationships with prestigious underwriters and the issuance of Type I hypothecations. A sovereign whose most recent bond is a Type I hypothecation is 15 to 20 per cent less likely to have arranged with Barings or Rothschild in the last two years, fixing the level of fiscal transparency.

\section{V.3 The 1872 Crisis and What We Can Learn from It}

Interpreting sovereign hypothecations as an innovative information technology, it is easy to realize that it was exposed to one vulnerability - the possibility of manipulation. In fact, as seen earlier in the case of the Moroccan loan, Type I hypothecations often tried to address that problem through reliance on British consuls who, the prospectus assumed, would be trustworthy. The evidence shows that this solution was not always accessible however. In such cases (when consuls did not have access to the relevant information for instance), other potentially less trustworthy intermediaries had to be involved, raising the possibility of exploitation. In fact, a collateral confidence crisis occurred in 1872, on the back of revelation of doctored contents in the prospectus of a loan to Honduras and triggering an enormous controversy. In this section, we use the episode for a final test of our theory of hypothecations as information technology: If the concern had been that hypothecations created unwarranted beliefs among investors, the policy recommendation ought to have been to forbid their use.

Yet this is not what happened. Instead, as we show from contemporary debates and from the archive of the London stock exchange where the matter was eventually resolved, the solution to the problem came with the help of a regulation that made intermediaries liable for publication of wrongful data in prospectuses. This is consistent with our view that hypothecations were an information technology that spurred market inclusion of opaque borrowers. Faced with a confidence crisis that undermined the informational value of collateral, the response of authorities was to create incentives that would restore their credibility as valuable sources of information. 
The trigger for the early 1870 s controversy over sovereign collateral was an attempted float of a new hypothecated bond by Honduras to finance an ambitious "ship railway" project, meant to transport vessels across the Isthmus. The loan gave the railway and surrounding land as hypothecations, and the prospectus described the earning potential of the railway as determined by its ability to capture trade currently going through Cape Horn. On May 251872 however, as the loan was about to be launched, The Economist published an article that proved with the help of a reconstruction from international trade statistics that the numbers in the prospectus had been doctored. ${ }^{49}$ This spurred a confidence crisis and sovereign hypothecations came under attack. After the Honduras scandal, bondholders and the press voiced widespread concerns regarding the validity of sovereign hypothecations. Simultaneously, the foreign government debt boom of the 1860 s and early 1870 s ended in a wave of defaults, spurring further concerns over bankers' abuse. Our data, discussed in the Appendix, shows that the Honduras scandal ushered in an increase in the spreads of bonds specifically with Type I hypothecations and there is some limited evidence of contagion. This makes sense from the vantage point of our theory: Information is prone to crises of confidence that may induce regime-switches from belief to disbelief (Veldkamp, 2006).

We argue that the regulatory response reveals that contemporaries understood hypothecations as being an information technology. As they noted, the uniform outcome was that sovereign defaults never led to placing the collateral at the disposal of creditors. ${ }^{50}$ Nor had this led to more than halfhearted, sporadic efforts by creditors to repossess the hypothecated assets. This is consistent with our reading that investors understood their legal position. ${ }^{51}$ What is more, after the market collapse led to a debate over hypothecations, regulatory efforts concentrated on improving the information content of hypothecations rather than increasing the ease of repossession. Contemporaries might have suggested banning Type I hypothecations altogether as unsound or at least cautioned the public against them. Instead, they suggested creating incentives that enhanced the reliability of prospectuses. This lends support to the interpretation in this paper.

This began with the "Foreign Loans Registration" Bill introduced in British Parliament by H.B. Sheridan M.P. in March 1875. ${ }^{52}$ Sheridan was a corporate lawyer and foreign bondholder activist and his bill, would have compelled the agents of sovereign borrowers pledging hypothecations to register the assets with the Registrar of Joint Stock Company. Created as part the Joint Stock Companies Act of 1844, the Registrar had an informational role. It collected and kept available to the public, subject to a modest access fee, information such as the statutes of a company, the list

\footnotetext{
49 “The Honduras Ship Railway Loan,” The Economist, May 25, 1872, p. 639.

${ }^{50}$ Select Committee (1875; p. xlv).

${ }^{51}$ See Select Committee (1875, p. 151) for the meek, half-hearted attempts. Two other cases were Croyle v Dreyfus and Twycross v Dreyfus. According to the Times (August 2,1876) these latter attempts had been tried because the Chancellor Malins was himself a holder of hypothecated bonds and the Pall Mall Gazette (1 August 1876) suggested the "proceedings would have an indirect influence upon the bonds of 1872, and would tend to enhance their value". In the end, the matter was removed from his hand and transferred to Vice Chancellor Sir Charles Hall.

52 "A bill to provide for the compulsory registration of foreign loans." 1875 (60) (94) The Bill came in two readings with mild differences of language between the two.
} 
of its promoters and annual lists of shareholders. ${ }^{53}$ Another aspect of Sheridan's Bill was that intermediaries who would have falsified information would be guilty of misdemeanor and made personally liable of losses suffered by investors. Among the items whose manipulation was criminalized were the "particulars of revenue and taxes." In clear, the Bill created penalties for the manipulation of hypothecation information. When asked what the intention of the bill was, Sheridan answered that if the public were sure that all the hypothecations and mortgages were accurately stated in the prospectus, "states would find it much easier to raise money here." 54

In practice, the lawmakers and the British government alike were not too excited with the prospect of sponsoring a British bureaucracy in charge of certifying foreign government numbers. If the Registrar kept or divulged information that turned out to be false, who would be responsible? ${ }^{55}$ The Chancellor of the Exchequer Stafford Northcote directed the Bill for examination by the Select Committee on Loans to Foreign States, a simultaneously set-up parliamentary investigation. ${ }^{56}$ However, the suggestion that came back promoted a logic that was similar to that espoused by the Sheridan Bill. In fact, the final Report of the Select Committee recommended standardization of the language and format for hypothecation data. In particular, it suggested requiring contractors to provide in the prospectus a full statement of the "revenues, lands, forests, public works, or other property upon which the proposed loan is secured, and of prior charges, if any, upon such security." ${ }^{7} 7$ What is more, the recommendations drew on the logic of the Companies Act of 1867, which afforded a precedent for requiring a more standard prospectus prompt and for making false statements or willful omission a ground for a civil action.

Because foreign loans were the province of the stock exchange, the matter circled back to its governing body, the Stock Exchange Committee, which was encouraged to consider an adaptation of listing requirements. On Friday, January 21 1876, the sub-Committee for Rules and Regulations held a special meeting where it adopted the suggestion to introduce a new rule providing that "a statutory declaration be required from Contractors \& agents." 58 This rule, which was immediately adopted, followed directly from the prompt from the Select Committee. ${ }^{59}$ In fact, as suggested by the Report of the Select Committee, the technique borrowed from the Company Acts of 1867 the

\footnotetext{
${ }^{53}$ It had been amended by the Joint Stock Companies Act 1856. See Taylor (2013) for a discussion.

${ }^{54}$ Select Committee (1875, p. 274).

${ }^{55}$ Cohen (1876, p. 692) speaks of the hurdles involved in creating a "certifying tribunal for Foreign Loans".

${ }^{56}$ Marichal (1989); Flandreau (2016).

${ }^{57}$ Select Committee (1875, xlix).

${ }^{58}$ Archive LSE, MS14612/1 Minutes of the Committee for rules and regulations. Showing the import of the Select Committee's suggestion, the regulations considered were said to be "with special reference to the recommendation in the Report of the Select Committee of the House of Commons." For evidence of the adoption of the rule, see Mihill Slaughter, Rules and Regulations for the Conduct of Business on the Stock Exchange, London: Published under the authority of the Committee for General Purposes, 1880.

${ }^{59}$ Herman de Zoete made the first reference to statutory declaration in the Select Committee, during the interview of the Chairman of the stock exchange (Select Committee, 1875, p. 29). It came again in the interview of George Webb Medley a member of the stock exchange. As he recommended, "all statements of agents, contractors, brokers, on [prospectuses ought] to be made by statutory declarations, and the parties making them to be held civilly and criminally responsible for them" (Select Committee, 1875, p. 277-8).
} 
reliance on statutory declaration so as to aggravate wrongful factual statements. When registering a new company with the Registrar of Joint Stock Companies, the promoters had to sign a statutory declaration that the information they disclosed was accurate to the best of their knowledge. As explained in a contemporary legal publication, "were false or untrue in any material particular, the person willfully making such a false declaration would be deemed guilty of misdemeanor." 60 In a similar fashion, sovereign debt contractors making false disclosures when applying to the stock exchange, rendered themselves guilty of perjury and would have civil and criminal liability, since they would have been forced to sign a pre-printed text that they conscientiously believed their disclosures to be true. In other words, the mechanism did borrow from the law of the land tools that enabled criminalization of information manipulation in sovereign debt. This was expected to render safer the information released in prospectuses via hypothecations. ${ }^{61}$ While this regulatory intervention is consistent with our interpretation of hypothecations as instrument to disclose information, it is not consistent with the alternative, that sovereign debt collateral was a scam. Indeed, reliance on sovereign debt hypothecations and, consistently, their description in prospectuses would persist throughout the rest of the $19^{\text {th }}$ century and in fact well into the $20^{\text {th }}$ century.

\section{Robustness}

\section{VI.1 Effect of Smith v Weguelin}

The first robustness we perform is a "sanity check" for the absence of the Smith v Weguelin effect. We perform the original Bai-Perron test on finer, monthly data. This monthly dataset covers only a subset of the years we cover in the yearly yield panel ${ }^{62}$ and focuses only on hypothecating entities. We want to be sure that the findings on the finer monthly dataset replicate on the yearly one. To be sure of consistency we estimate:

$$
\text { Yield }_{b c y t}=\alpha+\eta_{t}+\sum_{c \in \text { Hyp. }} \zeta_{c} \text { CountryPost1869 } 9_{b c y}+\Gamma X_{b c y t}+\epsilon_{b c y t}
$$

\footnotetext{
${ }^{60}$ Solicitors' Journal, Nov 3, 1877

${ }^{61}$ In practice, the standardized text used in those declarations which were to be communicated to the Committee of the Stock Exchange through the agency of the secretary of the shares and loans department, shows them as derived from the Declarations Act of 1835 (1835 c. 62). The text which contractors had to sign was printed on a card, leaving for the declarer to fill the blanks.

${ }^{62}$ This is due to data collection constraint, as extraction of prices from The Course of Exchange is a time consuming procedure. We are working on further extensions of our dataset.
} 
on a restricted panel including years up until and including 1872, to exclude the spillovers of the Honduras crisis. Here the main variables of interest are the CountryPost ${ }_{b c y}$ dummies. They equal to one whenever $t>=1869$ and the country has had any collateralized bond floating by 1869 . Controls include the standard set of year fixed effects, sovereign fixed effects, a dummy for perpetuities, for the presence of a project description in the prospectus, the prestige of the underwriter, and the log of volume and maturity of the bond.

Figure 5 summarizes the findings from estimation of Equation 4. It shows no significant reaction for hypothecating countries as a whole, except for Honduras, which suffers from the onset of its crisis. We can conclude that the behavior of spreads in the yearly dataset is coherent with the monthly one.

\section{VI.2 Hypothecations and Yield Behavior}

We propose three kinds of robustness tests: First, we want to further check that the result of a Type I premium does not depend on Type II related variation. Second, we want to be sure that the lower required yield for Type I bonds is the effect of controlling for country risk, not of lower risk of countries issuing both hypothecated and non-hypothecated bonds.

Finally, we want to gauge the robustness of the result to a broad spectrum of modifications to clustering scheme, sample selection rules (in terms of Maturity) and inclusion/exclusion of bonds from the Type II dummy.

The first kind of robustness test implies estimating Specification 1 again on the restricted sample of observations excluding Type II bonds. In Table 5 we show how this does not materially affect the results in any way.

The second kind of robustness means to estimate Specification 1 on the restricted sample of observations belonging to sovereigns that issued Type I bonds and other types of bonds. The results are summarized in Table 6 . Here we record how the pooled coefficient remains positive and relatively large, even though it loses power, while the within coefficient stays negative, significant and, after fully accounting for bond characteristics, close in magnitude to what reported in Table 2.

For the third and last kind of robustness, we follow Simonsohn, Simmons, and Nelson (2020) and present Specification Charts. ${ }^{63}$ Our objective is to show a thorough sensitivity analysis of our estimates and standard errors to the exclusion of bonds with short maturity, alternative clustering schemes, alternative definitions of what counts as Type I or Type II bond, and combinations

63 The code employed to obtain the graphs is a marginal modification on the code made available by Hans $\mathrm{H}$. Sieversten at https://github.com/hhsievertsen/speccurve. 
thereof. Specification Charts allow us to present many such tests in a parsimonious and transparent way.

Robustness to sample selection in terms of bond maturity and clustering is almost "mechanical". We will instead briefly comment on the robustness to changes in the Type I/Type II definitions. The coding of collateral clauses as Type I or II carries a (limited) degree of subjectivity. For example, the scope of hypothecations achieved through mortgage deeds depends strongly on a foreigner's access to one country's courts. On balance, we decide to code as Type II Italian and Spanish mortgages and as Type I the Swedish. Still, if such choice were crucial for the withinsovereign Type I premium, this would be concerning. To mitigate similar concerns, we want to explore how our results depend on perturbations on how we code prospectuses containing different collateral clauses.

In Figure 6 and 7 we plot point estimates and confidence intervals for estimates of $\beta$ from Equation 1, always including all controls in the different estimations. On the left of the graph, we can see the within-sovereign estimates, while we can see the pooled estimates on the right of the graph. Below the graphs, we record with black dots under which clustering scheme and sample selection the estimate is obtained.

The plots show that results are robust to alternative clustering schemes, Maturity inclusion criteria, and marginal perturbations on which collateral clauses we code as Type II. We always record a strong selection effect associated with the use of sovereign hypothecation. Hypothecated bond yields are 350 basis points above the average non-hypothecated bond yield. At the same time, we always detect a statistically and economically significant within-country premium of about 100 basis points, against non-hypothecated bonds issued by the same sovereign.

\section{VI.3 Hypothecations and Transparency}

We further probe with Specification Charts our results on the correlation between proxies of transparency based on the Statesman Yearbook (presence of recent or updated revenue data and age of data) and accessing the market via hypothecated bonds. In this case, we have three residual concerns.

First, we want to ensure no single year (i.e. Yearbook volume) is driving all of our correlation. Second, our results should not depend on the decision to control for each sovereign's past issuing behavior up to $y-2$. Controlling for issuing behavior up to $y-1, y-3$, etcetera should not affect what we find. Third, Type I bonds are collateralized bonds in which we are positively sure the information aspect is the only one that matters. For this reason, we present results in Table 3 focusing on sovereigns accessing the market through Type I bonds. Still, Type II collateral clauses do also convey information. Thus, we expect our result to be broadly robust to doing away with the distinction in the estimation of Equation 2.

In Figure 8, 9 and 10 we plot point estimates and confidence intervals for estimates of $\beta$ from Equation 2. We show results for both the specification controlling for country-risk with a lag of volume-weighted yield or lag of GDP per capita. Below the graphs, we record under which 
specification and which horizon of control for past issuing behavior we obtain each estimate with black dots. Results hold across a broad spectrum of specifications and alternative criteria for variable construction.

Finally, we apply similar robustness tests to the result from estimating Equation 3. Here we are specifically concerned about the possible instability of our result to alternative combinations of information control and different time-horizons capturing the last time the sovereign dealt with Rothschild or Baring. Figure 11 displays the broad robustness of our result to such concerns.

\section{Conclusions}

This article has studied the perplexing collateralization of sovereign debt, a relevant process today, and one that has thrived throughout history. The study documented its expansion during the onset of the first age of globalization. It is perplexing as to why investors would secure difficult to enforce sovereign debt with the help of just equally difficult to enforce collateral. Recent data on the matter is scarce, while it is more abundant for the first age of globalization and the legal context is better documented and provides more perspective. Moreover, the 19th-century offers a "clean" setting where repossession was impossible owing to absolute sovereign immunity. This gives us a unique opportunity to study collateral separately from court enforcement and investigate whether and how it can still help curb asymmetric information and moral hazard.

We show that the 19th-century investing public understood perfectly that sovereign collateral could not be enforced, though they valued collateralization. By drawing on the Smith verdict returned in 1869 by the British Court of Chancery, we show that the lack of enforcement was fully priced. Next, drawing on a library of 117 sovereign bonds' prospectuses, collected and controlled by hand and covering the universe of foreign sovereign debt listed in the London stock exchange between 1849 and 1875 , we found that hypothecations were widespread, representing more than half of the sample (68 occurrences). Matching this with price data, we show that investors were prepared to pay an economically significant premium for collateralized bonds. To explain why, we argue that sovereign hypothecations were a valuable financial innovation that enabled the production of information. Collateralization of sovereign debt was an institutional mechanism that addressed information asymmetries regarding individual streams of income.

Examining the individual structure of each hypothecation contract, we documented how only 12 hypothecated bonds created a mechanism for recourse upon default (or something that looked like it), using either a formal deed of trust or relying on pre-existing international treaties or international law, which provided exceptions to sovereign immunity. Nevertheless, for the remaining 56 hypothecated bonds prospectuses, the majority of the group and the de facto "boilerplate", the collateralization mechanism did not envision repossession. Instead, it created a monitoring technology, bolstered by credible disclosure mechanisms. These hypothecations prescribed the involvement of trustworthy information intermediaries and in this way they breached critical information asymmetries. 
Empirically, we established that borrowers who relied upon the hypothecation boilerplate were comparatively more opaque. To do this, we collected novel fiscal transparency measures, tapping material from The Statesman's Yearbook, the leading contemporary instrument to document macro-financial performance. We also documented British regulatory interventions on the use of collateral in sovereign lending and demonstrated that they are inconsistent with the view that regulators were skeptical of hypothecations, despite their total lack of repossession provision. Instead, regulators recognized that sovereign hypothecations were at the bottom an information technology, and, accordingly, they helped by creating penalties for wrongful disclosures.

We interpret our findings as suggesting that collateral's role in mitigating information asymmetries and moral hazard stands even in the absence of enforcement and repossession. Indeed, collateral arrangements may serve to bring within investors' scope aspects of the creditors' performance that would be otherwise difficult to observe. In the instance we studied, collateral clauses tasked information intermediaries with performing certain information revealing tasks, creating a level playing field among investors. In other words, the historical record lends support to the conclusions of Gambacorta et al. (2020), who documented in the case of Chinese corporations that "big data" can substitute for enforceable collateral. What the sovereign hypothecation mania of the $19^{\text {th }}$ century demonstrates is that, in fact, collateralization sans enforcement is a mechanism to produce data. In this case, the involvement of lawyers (and regulators) is motivated not by the need to secure enforcement, but by the need to produce trustworthy information.

To sum up, instead of securing lenders by using courts to increase the borrowers' default cost, nonenforceable collateral pledges built information accountability institutions from scratch. Circling back to the questions with which we opened this paper, we note that such institution building logic may explain why new international lenders (especially China) entering new markets display an intriguing reliance on collateralizations, which lawyers puzzle over. In our interpretation, the explanation would be that their lending activities are by contrast less reliant on established international institutions and mechanisms. 


\section{Appendices}

\section{Appendix I. Type II Hypothecations: An Overview.}

In this appendix, we provide a discussion of individual Type II hypothecations, proceeding by alphabetical order. As indicated in the text, Type II hypothecations distinguished themselves from the rest in that they made some effort at creating a template enabling some form of repossession of the collateral. Accordingly, the following discussion identifies in what respect it may be argued that such a template was created, and emphasizes the mechanism, legal or other, which was likely to secure that effect. It is important to emphasize that, by allocating individual bonds to this category, we do not pass any definitive judgment on the efficiency of the individual schemes, though we make occasional remarks. A weak or non-credible Type II hypothecation may perform worse than a Type I hypothecation in terms of risk elimination. In other words, Type II does not mean $100 \%$ enforceable. Likewise, we do not suggest at all that the various Type II hypothecations described below were similar to one another. An interesting question would be to study systematically their individual performance, but it is beside the point we make here. Finally, Type II hypothecations may (and in general do) include a Type I mechanism as well. In other words, what warrants in our approach exclusion of a given debt contract from the Type I category and its inclusion in this appendix is the presence of a mechanism that may be interpreted as conducive of repossession or quasi-repossession.

\section{1) Bolivia: The Trust Deeds of the Erlanger Loan of 1872}

The Bolivian loan of 1872 is one of the most complex pieces of legal-financial engineering in our population of sovereign debt contracts. The project that gave rise to the loan was an attempt to throw Bolivia open to trade via the Amazon River, with the help of the construction of a route through tributaries of the Amazon and a railway line to be built from the proceeds of the loan. A group of promoters acting as agents for the government of Bolivia received navigation and construction rights and launched three companies: A navigation company (the National Bolivian Navigation Company or NBNC), a railway company (the Madeira and Mamoré Railway Company) and a construction company (Public Works Construction Company) to build the road. ${ }^{64}$ The plan foresaw the division of custom revenues accruing from the trade this would create between the government (one-fourth) and the navigation company (three-fourth). Both revenue streams were pledged as special security to the bondholders. In particular, should the government fail to service the loan, the three-fourth of the custom revenues collected by the company would be paid over to the bondholders.

So far, the arrangement came under the traditional hypothecation system. The unique feature of the arrangement was the setting up of two detailed deeds of trust. ${ }^{65}$ The first granted to bondholders, through the agency of trustees, the right to inspect the books of the navigation company and, in case profits that were to cover the creditors were being withheld, the trustees had the right to enter "at once as receivers into possession of all property and assets of the company." Furthermore, in case of sovereign default, the bondholders would become the owners of the

\footnotetext{
${ }^{64}$ The NBNC was incorporated in 1870 in New York by an Act of Congress, while both the MMRC and the PWCC were incorporated in London in 1871 under the British Companies Act of 1862 and 1867. See Flandreau (2016) for details on this loan.

65 See Anonymous (1873).
} 
company. The second, and arguably even more powerful deed created for the protection of the bondholders intimated the trustees to "retain out of the proceeds of the loan [...] a sum equal to the contract price of the railway, and temporarily invest and apply the same from time to time in payment for the works as they proceeded." 66 The money was put in a safe at the Bank of England and could not be touched without the consent of the trustees, who had very clear instructions regarding how the money ought to be spent. The key objective was the completion of the railway, and no money was to be disbursed for any other purpose.

Since most of the money remained within the control of the bondholders, the security was material. Some observers rationalized in this way the initial success met by the Bolivian loan, given the limited credit Bolivia enjoyed. ${ }^{67}$ In the end, the loan turned out to be a failure because the project itself collapsed on the back of flawed calculations. The Bolivian government suspended the payment of the interest and, since the road had not been completed, no revenues could be paid over to creditors. Even then, trustees were able to suspend the construction in order to avoid the dilapidation of the money in trust. As the funds at the Bank of England had been wisely invested in US securities, they kept increasing in value. What is more, British courts declared themselves competent and eventually ordered the release of the funds to bondholders. While this was rather messy, the epilogue does confirm that through the help of a deed of trust, assets could be detached from a sovereign's reach and plausible collateralization could be achieved.

2) Commission of the Danube Loan, 4\% 1869: International Law and International Receiverships. This loan gave as collateral the "tolls and duties" levied at the Sulina mouth of the Danube (on the Black Sea) by the European Commission of the Danube. The Commission was an international administrative entity established by the Treaty of Paris of 1856, which settled the Crimean War. Austria, France, Prussia, Russia, Sardinia, Turkey and the United Kingdom run the venture, vested with the authority to manage and improve the circumstances of international navigation on the Danube river. In November 1865, a public act signed by Austria, France, Italy, Prussia, Russia, Turkey and the United Kingdom had placed the Commission, its officers, works and establishments "under the protection of international law." In 1869, the Commission raised $£ 135,000$ on the London Stock Exchange offering as security to creditors the tolls on the Danube river and "full powers of receivership in case of default." 68

To understand how this would play out, the important element is that the loan was guaranteed by France, Italy, the North German Confederation (Prussia), Turkey and the United Kingdom. In the event of a default, these countries, which had a majority stake in the Commission, would be called in to make up for the difference, and simultaneously they would take care of implementing the receivership system. In other words, a group of sovereigns would manage the collateral, acting collectively and abiding in their intercourse with one another by the rules of international law. At 75 basis points above Consols, the spread at issue of this loan was among the lowest ones extant for hypothecations.

\footnotetext{
${ }^{66}$ Prospectus, Times, January 20, 1872.

${ }^{67}$ According to the later opinion of the Lord Chancellor Hugh Cairns: "I think it is obvious that if the money had not been placed in the hands of the trustees the loan would not have been obtained." Flandreau (2016, p. $114,359)$.

${ }^{68}$ Prospectus for the European Commission of the Danube, 4\% loan, London Standard, March 8, 1869.
} 


\section{3) Egypt: The Khedive's Private Loans of 1866, 1867, 1870.}

The Egyptian loans of 1866 "Loan of the Viceroy of Egypt" (7\%), 1867 "Egyptian 9\% Vice Roy loan", and 1870 "Mortgage loan of His Highness the Khedive of Egypt (7\%)" had a special status in that they pledged, not the revenues of Egypt, but various forms of private property belonging to the ruler in his private capacity. Because the pledge was private, it created grounds, in theory at least, for repossession. For that reason, these bonds were listed in the London stock exchange under "miscellaneous".

As for the Spanish Quicksilver loan, it was an open question as to what would be the treatment of such claims in case of litigation. As it turned out, a possible jurisdiction would be the Mixed Courts, but they did not exist at the time of the private loans (they were not created until 1875). Significantly, when they came into being, their mandate included matters that had to do with the Khedive's land and that of his family, so long as no question of acts of sovereignty arose. ${ }^{69}$ The important point is that a formal repossession mechanism was at least contemplated.

a) "Daira" loans of 1866 and 1870: The loan of 1866 (known as the "Viceroy's Private Domains Mortgage Loan") was, according to the terms of the prospectus, guaranteed by the "immense private property of his Highness Ismael Pasha, Viceroy of Egypt". The prospectus especially pledged a "mortgage of 364,930 feddans (about 375,000 acres) of cultivated lands, hypothecated in due legal form to that effect by His Highness." A deed of hypothecation (or "Kachf") was deposited at the Bank of England, enabling the creditors to secure it in case of nonperformance. In effect, the grantor of the security was the Daira, the administrator of the private domains of the Khedive. The prospectus recited the merit of the security vested in the reputation of the Daira, stating that the Daira's "acceptances or obligations" have always been "taken up by capitalists in preference to all other negotiable securities in Egypt."70

By its legal/financial design, the loan of 1870 was similar in its broad lines to the $7 \% 1866$ Viceroy Loan. It likewise involved the Daira (the nickname of the loan actually became "Daira Sanieh Loan") and a deed of hypothecation deposited at the Bank of England. Rather than being for land managed by the Daira as in 1866, however, the pledge was both for "the whole of the free revenues" of the Daira and for 150,000 feddans of land to be devoted to the cultivation of cane sugar (an estimate of the expected value of the total production of sugar was provided). ${ }^{71}$

b) Mortgage loan of His Highness the Khedive of Egypt (9\%) (also known as Mustapha Pasha's Domains Loan) of 1867. It had served to purchase land for Royal Prince Mustapha Pasha. ${ }^{72}$ The loan, signed by the Khedive, gave as security the Khedive's personal "free revenues" plus a guarantee by the Egyptian government. In this case, unlike with the two loans previously discussed, there was no deed of hypothecation for the creditors. Instead, the Egyptian government kept the title deeds of the property purchased for Royal Prince Mustapha Pasha as security, so that the Egyptian government would seize the collateral and take up the service in case of nonperformance by the Khedive.

\footnotetext{
${ }^{69}$ See Hoyle (1987, p. 437). On the making of the Mixed Courts, Hoyle (1986).

70 Times, March 21, 1866. The Daira ran the Khedive's own possession and especially his cotton plantations, which grew to an unprecedented scale during the American civil war. These were experiencing difficulties due to the return to more normal conditions after the war (see Landes, 1958).

${ }^{71}$ See the Prospectus in Times, April 26, 1870.

${ }^{72}$ Landes (1958, p. 106).
} 
As stated, the special status of these three loans was identified by the fact that, in the London stock exchange they were listed, not under "foreign stocks" (where sovereign debt was normally listed) but under "miscellaneous." This reflected the view that the Khedive loans were private in character. However, some newspapers that informed investors on the state of the market, such as the Investor's Monthly Manual, did not identify the loan of 1867 in the similar way, though they marked the loans of 1866 and 1870 as "secured on private domains". This was possibly because the deed of hypothecation was not in the hands of the bondholders but in the hands of the Egyptian government. ${ }^{73}$ Because it included for the guarantor the right to seize the asset, it is more similar in logic to the Ottoman loan of 1855 than to the two other Khedive loans.

\section{4) Italian Government: Loans through Private Companies}

Two Italian loans - the State Domain Loan of 1865 and the Italian Tobacco Loan of 1870 - created a genuine repossession mechanism. In both cases, they achieved this goal by creating a private entity, owned by a combination of domestic and foreign investors and responsible for servicing the loan. Rather than placing the mechanism within the orbit of a mortgage law and registry (as in the case of the Spanish Quicksilver loan) the chosen route was an Act of Parliament and it would be interesting to understand why. Because technically, the actual borrower was private, the two loans ended up like the Khedive loans under the "miscellaneous" section of the London stock exchange official price list, rather than under "foreign funds" though they were understood to be government loans.

\section{a) State Domain Loan, 5\% 1865.}

Unlike other Italian or Sardinian loans (since the Kingdom of Sardinia was a predecessor state of unified Italy), which exhibited Type I hypothecations, the State Domain loan included an original structure. ${ }^{74}$ The goal of the Italian minister of finances, Quintino Sella, had been to externalize to a private company the liquidation of state domains to obtain cash for the Government. The result was the creation of a financial entity that would supervise the sale of land, owned by banks and other financial intermediaries, which did advance money to the government against the security of a mortgage on state lands held by the Italian Land Company.

The structure of the arrangement, which led to the adoption of a convention between the Italian government and the Italian Land Company, was ratified by the Parliament. ${ }^{75}$ The agreement placed the Company under the supervision of a royal commissioner and tasked it with issuing the loan (Art. 15). The proceeds of the loan would enable the company to make an advance of a countervailing value to the Italian state (Art. 7-11). Italian treasury bills registered under the name of the Company secured the bonds, and a mortgage on the lands to be sold secured the bills in turn. Unlike what was the case in other Type II hypothecations, the convention stipulated that a law would substitute for the inscription of the security in the mortgage registries (Art. 12). As the liquidation of the state lands proceeded, the outstanding debt was progressively reimbursed, and the mortgages cancelled. Because of this peculiar arrangement, and although in the last analysis

\footnotetext{
${ }^{73}$ See, for instance, Investor's Monthly Manual, December 30, 1871, p. 398.

${ }^{74}$ An example of Type I hypothecation is provided by the Maremmana railway 5\% bond of 1862 .

${ }^{75}$ Anonymous (1865). Sources such as the Investor's Monthly Manual, by contrast, recognizing that this was at heart a government debt, put it under "Italy".
} 
this was evidently a government loan, it was not listed under foreign stocks in the official stock exchange price list. Just like the Khedive Loans, this loan was listed under "miscellaneous."76

\section{b) Italian Tobacco Loan, 6\% 1870}

The Tobacco Loan is reminiscent in several respects of the State Domains loan. On July 26, 1868 a convention was signed between the Italian government, the Regia Cointeressata, a partnership of Italian and foreign capitalists who acquired the right to farm the country's state monopoly over tobacco and, finally, representatives of Stern brothers, the contractors of the loan. ${ }^{77}$ The convention stipulated that the capitalists were pledging to provide the Italian treasury with 180 millions of gold lire in effective capital. Article 5 of the convention stipulated that a share of the company's profits would be set aside annually to fund interest and amortization charges of a loan. Article 23 described instead the money transfer process. ${ }^{78}$

The convention did not detail what would happen in the event of a default, but the legal material shows the logic. It trickled down from the fact that the Regia, rather than the Italian Treasury, was responsible vis-à-vis creditors. The profits of the Regia earmarked to pay creditors were sent each year to the Cassa dei Depositi e Prestiti (an institutional investor with custodian responsibilities) or to the Banca d'Italia (the Bank of Italy), which assumed trusteeship functions. These institutions acted as assignees of the revenues of the Regia for the benefit of creditors. The Treasury was then to take care of paying the bondholders from these funds. If the money was diverted, then creditors would be able to secure a freeze of the funds in the future. As a result, the arrangement created a genuine repossession system.

\section{4) Ottoman Loans of 1854, 1855 and 1871: The Role of International Treaties}

Three Ottoman Loans pledged separate portions of the so-called "Egyptian Tribute," an annual payment to the Turks by Egypt, formally a vassal of the Ottoman Empire. The Tribute arose from a series of international treaties backed by foreign powers, giving them some limited authority to monitor the use. In one of them (the 4\% Ottoman Loan of 1855), the resulting mechanism came closest to giving creditors formal repossession rights. This was because it empowered the British and French governments, who guaranteed the loan, to take over the collateral. Put together, this meant that creditors were secured through intervention of the foreign government acting as de facto CSD.

\section{a) Ottoman Egyptian Tribute Loan, 6\% 1854}

The Turkish loan of 1854, issued on the eve of the Crimean War, was backed by an assignment from the Egyptian Tribute. Multiple statements in the media, especially by promoters of this loan,

\footnotetext{
${ }^{76}$ Sources such as the Investor's Monthly Manual, by contrast, recognizing that this was at heart a government debt, put it under "Italy".

${ }^{77}$ The Italian syndicate of financiers was led, as for the State Domain Loan, by the Credito Mobiliare Italiano.

${ }^{78}$ See Ceci (2015) for details on the history of the tobacco monopoly. The Convention of July 25, 1868 and the text of the following law that approved it are found in Regno d'Italia, Collezione delle leggi ed atti del governo del Regno d'Italia, Napoli 1868, p. 445 ff.
} 
emphasized the unique character of the hypothecation at the time and afterwards. ${ }^{79}$ Such statements stressed two aspects. First, observers argued that there was an instruction from the Sultan to the Khedive to direct a portion of the money from the Tribute to the bondholders via the Bank of England. Second, the firman (Ottoman decree) providing for the rights of creditors was deposited at the Bank of England. ${ }^{80}$

Our reading is that, per se, this did not achieve anything different from what Type I hypothecations obtained routinely. The previously mentioned features were not superior to the provisions of, say, the Moroccan loan discussed in the main body of the paper. The question was: Could the borrower, at will, redirect the funds before they would reach the reliable agent (such as the Bank of England)? The answer is, of course, that the borrower could. Rose and Staniforth (1876, p. 12) report that at one point in 1876 the Turkish government was "determined upon issuing an order to the Khedive to remit the Tribute direct to Constantinople" (as opposed to the Bank of England). This shows that issuing a new decree was always possible. Similarly, depositing of the firman for the loan in the Bank of England has been described by Anderson (1964, p. 50) as ensuring that it would be safe "from all risks of emendation" (a view shared by Du Velay 1903, p. 140). However, of course, a new decree could be issued. ${ }^{81}$

In our understanding, instead, what made the hypothecation unusual was its connection to international law. This had to do not with the hypothecation mechanism per se, which was generic, but with the nature of the asset hypothecated. The Egyptian Tribute was the product of an international treaty, of which Britain had been part, giving partial authority to the British government. Such obligation resulted from the London Convention of 15 July 1840 and of the Treaty of London of 1840, followed by the firman of February 1841 that granted the Khedive hereditary government of Egypt in return for the payment of a tribute. ${ }^{82}$ Unlike the enforcement of private claims, the enforcement of intergovernmental claims was a priority of the British state. Here, we speculate, the reasoning of supporters of the view that the pledging of the Egyptian Tribute created special rights may have been that the British government had grounds to bring pressure to bear on the Khedive of Egypt. The prospectus nodded at this by emphasizing that the loan had been "negotiated with the knowledge of the English Government; that her Majesty's Government is satisfied that the loan and the appropriation of the above-mentioned 30 million piasters, $£ 282,000$ per annum, of the Egyptian tribute are duly authorized by his Majesty the Sultan." 83 The media and subsequent discussion by bondholders amplified the meaning of the endorsement. $^{84}$

\footnotetext{
${ }^{79}$ For examples of strongly partisan views on the responsibility of the British government, see Office of the Egyptian Tribute Bondholders League (1876) and Shee (1876).

${ }^{80}$ Fenn (1855, p.265), Du Velay (1903, p. 140).

${ }^{81}$ Modern authors who have been impressed by such views include Dyson (2014, p. 153).

${ }^{82}$ The firman stipulating the terms of the tribute was itself dated May 1841. For the text of the decree, see Hertslet (1874, p. 578).

${ }^{83}$ Fenn $(1855$, p. 266). The initial amount of the loan had been $£ 5,000,000$, the interest being $6 \%$ and the amortization $1 \%$, the annual sum that was initially necessary to meet annual charges was $£ 350,000$, and the security pledged, or $£ 282,000$ produced an $80 \%$ coverage ratio. In the end, as only $£ 3$ million were raised and the annual charge came to $£ 210,000$. This left a margin of about $£ 75,000$ that would be pledged for Ottoman "Egyptian Tribute" Loan, 4\% 1855.

${ }^{84}$ A little before the loan was launched, the Times claimed that the "English government will likewise give a formal intimation that the claims of the subscribers will always be regarded as entitled particularly to their support." Times, August 12, 1854; The Chronicle read the prospectus as meaning that the English government
} 
Our examination of the evidence suggests that markets favored the Egyptian Tribute loan of 1854 compared to other Ottoman loans. For instance, it traded at an average $20 \%$ premium compared to another similar 6\% Turkish loan, made in 1858, a Type I hypothecation, secured by custom duties and the "octroi" (internal custom) in Constantinople. ${ }^{85}$ Finally, when the Ottoman default took place in the 1870s, it was stated that all the creditors of Turkey were to be treated equally, "the only exceptions being in the case of the Loans of 1854, which, owing to the political and legal questions involved, it was desirable to deal with exceptionally" (Rose and Staniforth (1876, p. 21) and a similar claim was made for the loan of 1871, discussed below). ${ }^{86}$ It was added that "His Highness [the Grand Vizier] understands the exceptional position of the Loans of 1854 and 1871, guaranteed by the Tribute of Egypt, and the legal and moral considerations which gave to the holders in those Loans rights which they would not hesitate to enforce." ${ }^{87}$ For its part, the British government remained willing to emphasize with the Porte the special status of the Tribute Loans at large, thus vindicating expectations. ${ }^{88}$ This gives a semblance of plausibility to the concept of repossession, unlike what is plainly the case under Type I hypothecations.

\section{b) Ottoman “Egyptian Tribute” Loan, 4\% 1855}

The background of the loan was also the Crimean war and more specifically, the June 27, 1855 convention between Britain, France and Turkey providing for the joint guarantee by France and Britain of a loan of up to $£ 5,000,000$ to fight Russia. According to Art. 3, the two guarantors were secured by a) the available balance of the Egyptian Tribute (the "Egyptian Tribute" Loan of 1854 not having been fully subscribed, there was a balance of $£ 75,000$ available as security), as well as b) the custom duties of Syria and Smyrna. ${ }^{89}$ These securities were designated in the Ottoman "Egyptian Tribute" Loan issued in August 1855 (Ayres, 1857p. 371).

Some sources emphasized that the guarantee provided by Britain and France reduced the default risk (Al, 2012; Esteves and Tuncer, 2016). Ayres (1857) describes the stock as affording a "secure investment in the market" because of the joint guarantee. The low spread-at-issue compared to consols was 60 basis points and reflected this. Nevertheless, from a legal point of view, the significance of the mechanism was that combination of international treaties and of the guarantee created by a quasi-deed of trust. According to the lawyer Edward Sudgen (later Lord Chancellor and known as Lord St Leonard): "By the Convention [of June 1855] we became, with France, assignees of [the Egyptian] Tribute [and of the Customs of Smyrna]." 90 In conclusion, if the

gave its "assurance that the hypothecation of the Egyptian tribute [. . . is properly secured to the subscribers of the loan." Morning Chronicle, August 17, 1854.

${ }^{85}$ The loan of 1858 had a shorter maturity, which should have favored it, yet our evidence suggests that the Egyptian Tribute traded at a premium of about $20 \%$ on average. The inference we make is that the security raised its value. (Data available from authors)

${ }^{86}$ A similar claim was made for the loan of 1871.

${ }^{87}$ Rose and Staniforth (1876, p. 11).

${ }^{88}$ See response to the Chancellor of the Exchequer, Sir Stafford Henry Northcote, to a parliamentary question: "As I mentioned yesterday, the Governments of England and France have made a joint representation to the Government of the Porte on the subject of the Tribute Loans generally." House of Commons, Hansard, "Turkey-Loans of 1854 And 1855-Explanation-Question"," March 9, 1877 Volume 232, Columns 1652.

${ }^{89}$ Herslet (1874, p. 529). For details see Ayres (1857).

${ }^{90}$ Hansard, House of Lords, August 6, 1855, Column 1857; There were, in fact, concerns over the obligation this created. The disputes in Parliament (Commons and House of Lords) underscored contemporary understandings of the legal and political nature of the lien thus created. In the same speech, Lord St. Leonard argued that the 
bondholders felt secure, it was because the British and French government were themselves secured through a right to repossess the assets pledged. Formally, the hypothecation created a valid trust, whose beneficiaries were the bondholders and whose assignees and trustees were the guarantor government(s).

\section{c) Ottoman “Egyptian Tribute” Loan, 1871}

The Ottoman 6 percent loan of 1871, initially for $£ 5,700,000$, was the last loan issued with the security of the Tribute of Egypt (see Office of the Egyptian Tribute Bondholders League 1876). On top of the general revenues of the Turkish Empire, it pledged "the portion of the Tribute now payable to the Porte [Ottoman Empire] by the Khedive of Egypt not applicable" to the loans of 1854 and 1855 (Prospectus, Times, September 5, 1871). ${ }^{91}$ Like the two other Khedive Loans, the Tribute Loan of 1871 offered a guarantee that had a peculiar status in international law. Unlike the loan of 1854 and 1855, this loan did not include any mention of the role of the British government, opening questions as to its relative standing (Office of the Egyptian Tribute Bondholders' League, 1876 , p. $11 \mathrm{ff}) .{ }^{92}$

Summarizing, we have, a) The Loan of 1855, with international guarantee along with Tribute and custom receivership enforceable by international action; b) The Loan of 1854 with British "recommendation" and the Egyptian Tribute as security; c) The Loan of 1871, with only the Egyptian Tribute. As inspection of the parliamentary debates after the Turkish default suggests, there was a hierarchy in the British government mind, between the Loan of 1855 on the one hand, and the loans of 1854 and 1871 on the other hand, which had a different status.

\section{6) Spanish Quicksilver Mortgage Loan 5\% 1870}

This loan gave as collateral the quicksilver mines of Almaden, which belonged to the Spanish government. ${ }^{93}$ Chabot and Santarosa (2017, p. 31) suggest that this loan "established the legal machinery to assure the mine's output was under the control of the bondholders" although the mechanism they describe is the same as hypothesized by Vizcarra in the case of guano (creditors

\footnotetext{
pledges would risk involving Britain in political complications in case of non-performance. On the other hand, the British Government, was eager not to take any financial responsibility upon itself, which required the pledges be maintained, because, as Lord Clarendon put it "the obligations [...] might possibly be evaded." Hansard, House of Lords, August 6, 1855, Column 1857, 1865; Likewise, fears were expressed that France would use the pretext of a lapse of payment by the Turks to invade Egypt or seize Syria, which further demonstrates that the existence of international treaties enabled repossession of the collateral; A similar concern that had already surfaced in the context of the loan of 1854; see Anderson (1964).

${ }^{91}$ The mechanism was the same as the one used before, that is, the interest and sinking fund was to be channeled through the Bank of England and from there paid to the bondholders via the intermediaries for the loan. The reason why there was a still room for using the Tribute was that it had been raised in 1866 to 150,000 purses or $£ 705,000$, after the Sultan "sold" to the Khedive of Egypt various privileges. After deducting the amount that was sent out for the service and amortization of the two previous loans, £422,000 remained as available balance, of which $£ 399,000$ were to be directed for the annuity of the new loan $(£ 5,700,000$ times 6 percent interest and 1 percent accumulative sinking fund $=£ 399,000$ ).

92 Following the Ottoman default, efforts were made to secure the official support for this loan, through a parliamentary bill (see Truth, January 18, 1877).

${ }^{93}$ We are extremely grateful to Alberto Gamboa for having helped us clarify this entry.
} 
would have been able to seize movable export good). ${ }^{94}$ Instead, we argue that in the event of a Spanish default, Rothschilds, who acted as agents for the bondholders would have become receivers of the mines. As explained by Martín (1980, p. 368) on the basis of the contract between the House of Rothschild and the Spanish government, which the prospectus only summarized, the loan and the security were to be "legally registered." This meant that both the loan and the security were to be inscribed in a property register. ${ }^{95}$ In fact, the arrangement harnessed the Spanish Law of 1861, which enabled to mortgage a designated physical property to secure lenders. ${ }^{96}$ The law involved the use of a notary who would record the loan and the registration of the security in a national registry which was publicly accessible and which prevented the re-hypothecation of the same security to another creditor. ${ }^{97}$ The system amounted to a genuine CSD. In case of nonperformance, it gave to the creditor a legal right, upheld by Spanish courts, to seize the asset designated by the borrower as security for the loan. Had the Spanish government missed a payment on the quicksilver loan, the House of Rothschild would be able to seize the mines of Almaden along with all the "machinery, buildings, works belonging to the Spanish State" which had been hypothecated too.

If the Spanish government had disputed the appropriation, it would have had to battle Rothschilds in Spanish courts. Possibly, the government would have been able to weigh in on judges. On the other hand, Rothschilds, with many investments in the country and connections in the political and business elites, were themselves formidable players. In other words, the bankers certified the financial arrangement (which stood apart from other loans to Spain), something they could do either because they knew that the legal process was robust enough to protect them or because they were confident in their ability to litigate successfully. ${ }^{98}$ This provides an interpretation for why the Quicksilver loan of 1870 was spared when other Spanish loans were defaulted upon in 1872. The House of Rothschild was playing a key role at the time in several aspects of the Spanish economy (see López-Morell, 2016, p.179).

To sum up, while significant uncertainties existed, the collateralization did create a genuine repossession mechanism. This can be seen by comparing the yield on "secured" Spanish debt and the yield on British "risk-free" consols, a spread of 330 basis points $(6.5 \%$ when British consols yielded about 3.2\%). This is large but on the other hand, an even larger spread is observed if we now look at unsecured Spanish debt. For instance, the perpetual 3\% 1869, yielded 9.70\% at the time of the Quicksilver issue, a 640 basis points premium over consols. However imperfect, the hypothecation had genuine elements. ${ }^{99}$

\footnotetext{
${ }^{94}$ As they write, "Spain had hypothecated the production of their quicksilver mine to the underwriters of the Quicksilver Loan, and the fear of legal difficulties selling quicksilver abroad convinced the Spanish crown that defaulting on the Quicksilver Loan was not worth the savings" (Chabot and Santarosa, 2017, p.32).

95 The text of the contract with Rothschilds (Art. 1) began with declaring that the loan would be accounted for in the "Property Registry."

${ }^{96}$ For the text and a contemporary discussion of the Spanish law of 1861, see Pantoja and Lloret (1861).

${ }^{97}$ Indeed, the prospectus indicated that the loan was "secured by a mortgage deed legally registered at Madrid and Almaden; all the machinery, buildings, works, belonging to the State, forming part of the stated property, being hypothecated as well as the mines" (Quicksilver loan prospectus, Times, May 31, 1870).

${ }^{98}$ See Flandreau and Flores (2009).

${ }^{99}$ On the capacity of such legal arrangements to protect against government predatory behavior, see Peña-Mir, (2019).
} 


\section{Appendix II. A Statistical Investigation of the 1872 Panic}

We here provide a brief description of the effects of the 1872 panic. We do so as the reaction of yields across different bond types is relevant to our argument and provides further evidence coherent with an information theory of sovereign collateral. We present this content in the Appendix, though, as we want to cover it more thoroughly in future work, with the help of more extended post-crisis data and precise accounting for the moment of default of each bond.

From Figure 12, we can see how 1872 marks the moment of a structural break in the behavior of hypothecated bond yields. We want to understand the heterogeneity of such a spike in yields across Type I and II hypothecations and whether it involved non-defaulting bonds. We indeed expect some spillover from the Honduras scandal, as it cast doubts on the use of non-enforceable hypothecations overall. To do so, we estimate the following Specification:

$$
\begin{aligned}
& \text { Yield }_{b c y t}=\alpha_{c}+\eta_{t}+\beta \text { Collateral. }_{b c y}+\text { Type } \mathrm{II}_{b c y}+ \\
& \gamma \text { Collateral., Post }{ }_{b c y}+\eta \text { Type II, Post }{ }_{b c y}+\Gamma X_{b c y t}+\epsilon_{b c y t}
\end{aligned}
$$

which modifies the within-sovereign version of Specification 1 by adding, first, interactions between the dummy Collateral, the dummy Type II and a Post dummy, taking value one for years after 1872 (included). The Collateral, Post dummy estimates the magnitude and verifies the statistical significance of the yield spike for hypothecated bonds. Instead, the Type II, Post dummy accounts for the greater default-protection granted by Type II hypothecations. Moreover, we include in the controls matrix X, a dummy for whether the bond $b$ ever defaults. Alternatively, we include bond-fixed effects, absorbing all observable and unobservable static heterogeneity across bonds.

In the first two columns of Table 7, we can appreciate how the spike of more than 2,000 basis points concerns only Type I bonds, and we cannot attribute it to pre-existing bond level differences. In the second two columns, we further control for the difference between the Type I collateralization spike and the defaulted bonds spike. Indeed, 29 of the 56 Type I hypothecations do default close to the 1872 shock. The concentration of defaults among Type I bonds tells of how specific the confidence collapse was, but still, evidence of contagion is even more interesting. Contagion points to the fact that even out of default state, after discovering number-fabrication, bondholders started a negative update of the premises under which they granted their credit. Premises grounded on the Type I clauses information machinery.

Admittedly, this last test spreads our data thin, as the post-1872 default dummy captures 103 valorized yield observations of the 170 attributable to Type I bonds after 1872. Even so, after accounting for bond-level heterogeneity, an economically large (700 basis) and marginally statistically significant (approximately $0.052 \mathrm{p}$-value) yield increase. We thus conclude with evidence that is at least suggestive of a contagion effect beyond what we can attribute to the diffused post-1872 default events. This further confirms the standalone relevance of information production in the Type I clauses phenomenon. 


\section{Tables}

Table 1: Descriptive statistics Cross Section

\begin{tabular}{lccccc}
\hline \hline Non-Hypothecated & & & & & \\
& & & & & \\
& Mean & S.D. & Min & Max & N. \\
Purpose & 0.449 & 0.503 & 0.000 & 1.000 & 49 \\
Yield at Issuance & 6.218 & 1.553 & 4.396 & 11.494 & 41 \\
Prestigious Underwriter & 0.531 & 0.504 & 0.000 & 1.000 & 49 \\
Bond Volume & 9.065 & 19.775 & 0.358 & 120.000 & 49 \\
Maturity & 44.230 & 23.649 & 4.000 & 100.000 & 37 \\
\hline
\end{tabular}

Type I Hypothecations

\begin{tabular}{lccccc} 
& Mean & S.D. & Min & Max & N. \\
Purpose & 0.679 & 0.471 & 0.000 & 1.000 & 56 \\
Yield at Issuance & 7.797 & 1.886 & 4.301 & 12.500 & 49 \\
Prestigious Underwriter & 0.054 & 0.227 & 0.000 & 1.000 & 56 \\
Bond Volume & 5.113 & 8.553 & 0.200 & 36.800 & 56 \\
Maturity & 29.161 & 22.462 & 1.500 & 100.000 & 56 \\
\hline
\end{tabular}

Type II Hypothecations

\begin{tabular}{lccccc} 
& Mean & S.D. & Min & Max & N. \\
Purpose & 0.417 & 0.515 & 0.000 & 1.000 & 12 \\
Yield at Issuance & 7.211 & 1.942 & 3.908 & 10.000 & 11 \\
Prestigious Underwriter & 0.167 & 0.389 & 0.000 & 1.000 & 12 \\
Bond Volume & 11.253 & 26.163 & 0.135 & 94.005 & 12 \\
Maturity & 27.417 & 24.898 & 7.000 & 100.000 & 12 \\
\hline \hline
\end{tabular}

Note: This Table presents descriptive statistics for the cross-section of bonds, broken down by hypothecation status of the bond. Purpose is a dummy taking value one if the bond's prospect includes a description of the purpose for which the debt is underwritten; Yield at Issuance Records the yield at which the bond is presented by the underwriter; Prestigious Underwriter is a dummy taking value one if the bond is underwritten by either Rothschild or Baring; Bond Volume records the issuance in millions of pounds; Maturity records the maturity in years. 
Table 2: Type I hypothecations helped weak sovereigns

\begin{tabular}{lccccc}
\hline \hline \multicolumn{7}{c}{ Dependent variable: } & Yield Spread & & & \\
Pooled & & & & & \\
Collateral. & $4.055^{* * *}$ & $3.954^{* * *}$ & $3.157^{* * *}$ & $2.895^{* * *}$ & $2.529^{* *}$ \\
& $(5.80)$ & $(6.12)$ & $(6.01)$ & $(4.96)$ & $(2.38)$ \\
Adj. $R^{2}$ & .1732 & .1778 & .2105 & .2195 & .2204 \\
\hline
\end{tabular}

Within

\begin{tabular}{lccccc} 
Collateral. & $-1.048^{* * *}$ & $-1.031^{* * *}$ & $-1.111^{* * *}$ & $-1.356^{* * *}$ & $-1.477^{* * *}$ \\
& $(-3.14)$ & $(-2.94)$ & $(-2.98)$ & $(-3.46)$ & $(-3.24)$ \\
Adj. $R^{2}$ & .7298 & .7305 & .7334 & .7352 & .7496 \\
\hline
\end{tabular}

\section{Pooled}

Collateral.

$4.61^{* * *}$
$(5.60)$
$-2.851^{* * *}$
$(-2.73)$
.2062

$4.542^{* * *}$
$(5.97)$
$-2.727^{* * *}$
$(-2.79)$
.2062
$3.743^{* * *}$
$(6.15)$
$(-2.87)$

3.5

(5.19)

$3.312^{* * *}$

Type II .2062

$-2.553^{* *}$

$-2.498^{* *}$

Adj. $R^{2}$ .2062

$\begin{array}{lll}.24 & .243 \quad .2426\end{array}$

\begin{tabular}{lccccc} 
Within & & & & & \\
Collateral. & $-.8742^{* * *}$ & $-.8433^{* * *}$ & $-.9245^{* * *}$ & $-1.061^{* * *}$ & $-1.239^{* * *}$ \\
& $(-3.27)$ & $(-2.85)$ & $(-2.75)$ & $(-3.13)$ & $(-2.97)$ \\
Type II & $-1.655^{* *}$ & $-1.742^{* *}$ & $-1.941^{* * *}$ & $-1.843^{* * *}$ & $-1.374^{* * *}$ \\
& $(-2.21)$ & $(-2.34)$ & $(-2.72)$ & $(-2.64)$ & $(-3.24)$ \\
Adj. $R^{2}$ & .7382 & .7397 & .7446 & .7448 & .7544 \\
Observations & 726 & 726 & 726 & 726 & 726 \\
\hline \hline
\end{tabular}

Note: The Table presents results from the estimation of Specification 1, with Pooled panels reporting estimates that only account for time fixed effect, and Within panels estimates conditional on sovereign fixed effects. The first two panels report the effects not accounting for the Type II dummy. We sequentially include covariates over the different columns. The first column shows estimates that only control for fixed effects and the perpetuity dummy; then, we add the log of the volume of bonds issued; the log of the maturity of the bond; the dummy for the presence of the loan's purpose in the prospect; the dummy for prestigious underwriters. Errors are clustered at the country-vintage of issuance level and t-statistics are in parenthesis. We report all the omitted coefficients estimates for the controls in Table 7, Extended Tables Appendix.

${ }^{*} \mathrm{p}<0.1 ;{ }^{* *} \mathrm{p}<0.05 ;{ }^{* * *} \mathrm{p}<0.01$ 
Table 3: Hypothecation and information

Dependent variable: $\quad$ Last issuance hyp.

\begin{tabular}{lccccc} 
Recent data & $-.3032^{* * *}$ & $-.3144^{* * *}$ & $-.2399^{* * *}$ & $-.2968^{* * *}$ & $-.2825^{* * *}$ \\
& $(-5.89)$ & $(-6.13)$ & $(-4.62)$ & $(-3.98)$ & $(-3.75)$ \\
$R^{2}$ & .0781 & .1049 & .274 & .1755 & .1827 \\
Observations & 372 & 372 & 341 & 154 & 154 \\
\hline
\end{tabular}

Dependent variable: $\quad$ Last issuance hyp.

\begin{tabular}{lccccc} 
Updated data & $-.1708^{* * *}$ & $-.1784^{* * *}$ & $-.2024^{* * *}$ & $-.2028^{* *}$ & $-.1923^{* *}$ \\
& $(-3.29)$ & $(-3.44)$ & $(-4.31)$ & $(-2.59)$ & $(-2.47)$ \\
$R^{2}$ & .0281 & .0518 & .2678 & .1288 & .1421 \\
Observations & 372 & 372 & 341 & 154 & 154 \\
\hline
\end{tabular}

Dependent variable: $\quad$ Last issuance hyp.

\begin{tabular}{lccccc} 
How old is the data & $.0575 * * *$ & $.057^{* * *}$ & $.0498^{* * *}$ & $.1384^{* * *}$ & $.1353^{* * *}$ \\
& $(4.75)$ & $(4.62)$ & $(3.47)$ & $(8.81)$ & $(8.62)$ \\
$R^{2}$ & .1063 & .1092 & .2601 & .2755 & .2824 \\
Observations & 297 & 297 & 280 & 153 & 153 \\
\hline \hline
\end{tabular}

Note: The Table presents results from the estimation of Specification 2 across different information availability proxies. Information proxies are (from first to last panel), a dummy taking value one if the revenue information for sovereign $c$ reported in Yearbook volume $y$ is less than two years old; a dummy taking value one if revenue information for sovereign $c$ in Yearbook volume $y$ is different from information for the same sovereign in volume $y^{-1}$; a discrete variable recording how old is revenue information published in volume $y$ of the Yearbook regarding each sovereign $c$. Columns present (starting from left) crude estimate of the relationship between transparency and the use of Type I hypothecations; estimates conditional on a dummy for whether sovereign $c$ issued any bond in the last two years; estimates conditional on recent issuance dummy and the lag of volume weighted yield for country $c$; estimates conditional on recent issuance dummy and reconstructed GDP per capita in 2011\$; estimates conditional on GDP and lag weighted yield both.

${ }^{*} \mathrm{p}<0.1 ;{ }^{* *} \mathrm{p}<0.05 ;{ }^{* * * *} \mathrm{p}<0.01$ 
Table 4: Hypothecation and prestigious underwriters

\begin{tabular}{lccccc}
\hline \hline & & & & & \\
\multicolumn{1}{c}{ Dependent variable: } & Last issuance hyp. & Info variable: & Recent data \\
Recent prestigious & & & & & \\
& $-.3505^{* * *}$ & $-.5334^{* * *}$ & $-.5027^{* * *}$ & $-.4058^{* * *}$ & $-.4104^{* * *}$ \\
$R^{2}$ & $(-6.17)$ & $(-8.25)$ & $(-7.68)$ & $(-5.21)$ & $(-5.29)$ \\
Observations & .1265 & .2 & .3575 & .2306 & .2391 \\
\hline
\end{tabular}

Dependent variable: Last issuance hyp. Info variable: Updated data

\begin{tabular}{lccccc} 
Recent prestigious & $-.3864^{* * *}$ & $-.5711^{* * *}$ & $-.5006^{* * *}$ & $-.4543^{* * *}$ & $-.4552^{* * *}$ \\
& $(-6.97)$ & $(-8.91)$ & $(-7.40)$ & $(-5.58)$ & $(-5.60)$ \\
$R^{2}$ & .0868 & .1604 & .3491 & .1992 & .2127 \\
Observations & 372 & 372 & 341 & 154 & 154 \\
\hline
\end{tabular}

Dependent variable: Last issuance hyp. Info variable: How old is the data

\begin{tabular}{lccccc} 
Recent prestigious & $-.3628^{* * *}$ & $-.4832^{* * *}$ & $-.4487^{* * *}$ & $-.3386^{* * *}$ & $-.3409^{* * *}$ \\
& $(-6.91)$ & $(-7.48)$ & $(-6.51)$ & $(-4.71)$ & $(-4.73)$ \\
$R^{2}$ & .1693 & .2008 & .3377 & .3143 & .3216 \\
Observations & 297 & 297 & 280 & 153 & 153 \\
\hline \hline
\end{tabular}

Note: The Table presents results from the estimation of Specification 3 using different information availability proxies as controls. Information proxies are (from first to last panel), a dummy taking value one if the revenue information for sovereign $c$ reported in Yearbook volume $y$ is less than two years old; a dummy taking value one if revenue information for sovereign $c$ in Yearbook volume $y$ is different from information for the same sovereign in volume $y^{-1}$; a discrete variable recording how old is revenue information published in volume $y$ of the Yearbook regarding each sovereign $c$. Columns present (starting from left) crude estimate of the relationship between the use of Type I hypothecations and relationships with prestigious underwriters; estimates conditional on a dummy for whether sovereign $c$ issued any bond in the last two years; estimates conditional on recent issuance dummy and the lag of volume weighted yield for country $c$; estimates conditional on recent issuance dummy and reconstructed GDP per capita in 2011\$; estimates conditional on GDP and lag weighted yield both.

${ }^{*} \mathrm{p}<0.1 ;{ }^{* *} \mathrm{p}<0.05 ;{ }^{* * *} \mathrm{p}<0.01$ 
Table 5: Dropping Type II bonds

\begin{tabular}{|c|c|c|c|c|c|}
\hline Panel A & Dependent variable: & & & & \\
\hline Type I & $\begin{array}{c}\text { Crude Yields } \\
4.611^{* * *} \\
(5.60)\end{array}$ & $\begin{array}{c}\text { Crude Yields } \\
4.564^{* * *} \\
(6.04)\end{array}$ & $\begin{array}{c}\text { Crude Yields } \\
3.659^{* * *} \\
(6.33)\end{array}$ & $\begin{array}{c}\text { Crude Yields } \\
\text { 3.361*** } \\
(4.87)\end{array}$ & $\begin{array}{c}\text { Crude Yields } \\
3.401^{* * *} \\
(2.67)\end{array}$ \\
\hline Year FE & $\checkmark$ & $\checkmark$ & $\checkmark$ & $\checkmark$ & $\checkmark$ \\
\hline Adj. $R^{2}$ & .2073 & .2065 & .2418 & .2454 & .2442 \\
\hline Observations & 644 & 644 & 644 & 644 & 644 \\
\hline Panel B & Dependent variable: & & & & \\
\hline Type I & $\begin{array}{c}\text { Crude Yields } \\
-.6651^{* * *} \\
(-3.56)\end{array}$ & $\begin{array}{c}\text { Crude Yields } \\
-.6469^{* * *} \\
(-3.20)\end{array}$ & $\begin{array}{c}\text { Crude Yields } \\
-.6804^{* * *} \\
(-2.80)\end{array}$ & $\begin{array}{c}\text { Crude Yields } \\
-.8177^{* * *} \\
(-3.05)\end{array}$ & $\begin{array}{c}\text { Crude Yields } \\
-.8954^{* * *} \\
(-2.86)\end{array}$ \\
\hline Year FE & $\checkmark$ & $\checkmark$ & $\checkmark$ & $\checkmark$ & $\checkmark$ \\
\hline Country FE & $\checkmark$ & $\checkmark$ & $\checkmark$ & $\checkmark$ & $\checkmark$ \\
\hline Adj. $R^{2}$ & .761 & .7609 & .763 & .7632 & .7635 \\
\hline Observations & 644 & 644 & 644 & 644 & 644 \\
\hline
\end{tabular}

Note: The Table presents results from the estimation of Specification 1, with Panel A reporting the pooled estimates of the correlation between yields and hypothecations, and Panel $\mathbf{B}$ the within estimates; t-statistics are in parenthesis. We sequentially include covariates over the different columns. The first column shows estimates that only control for fixed effects and the perpetuity dummy; then, we add the log of the volume of bonds issued; the log of the maturity of the bond; the dummy for the presence of the loan's purpose in the prospect; the dummy for prestigious underwriters. Errors are clustered at the country-vintage of issuance level.

${ }^{*} \mathrm{p}<0.1 ; \quad{ }^{* *} \mathrm{p}<0.05 ; \quad{ }^{* * *} \mathrm{p}<0.01$ 
Table 6: Within variation robustness

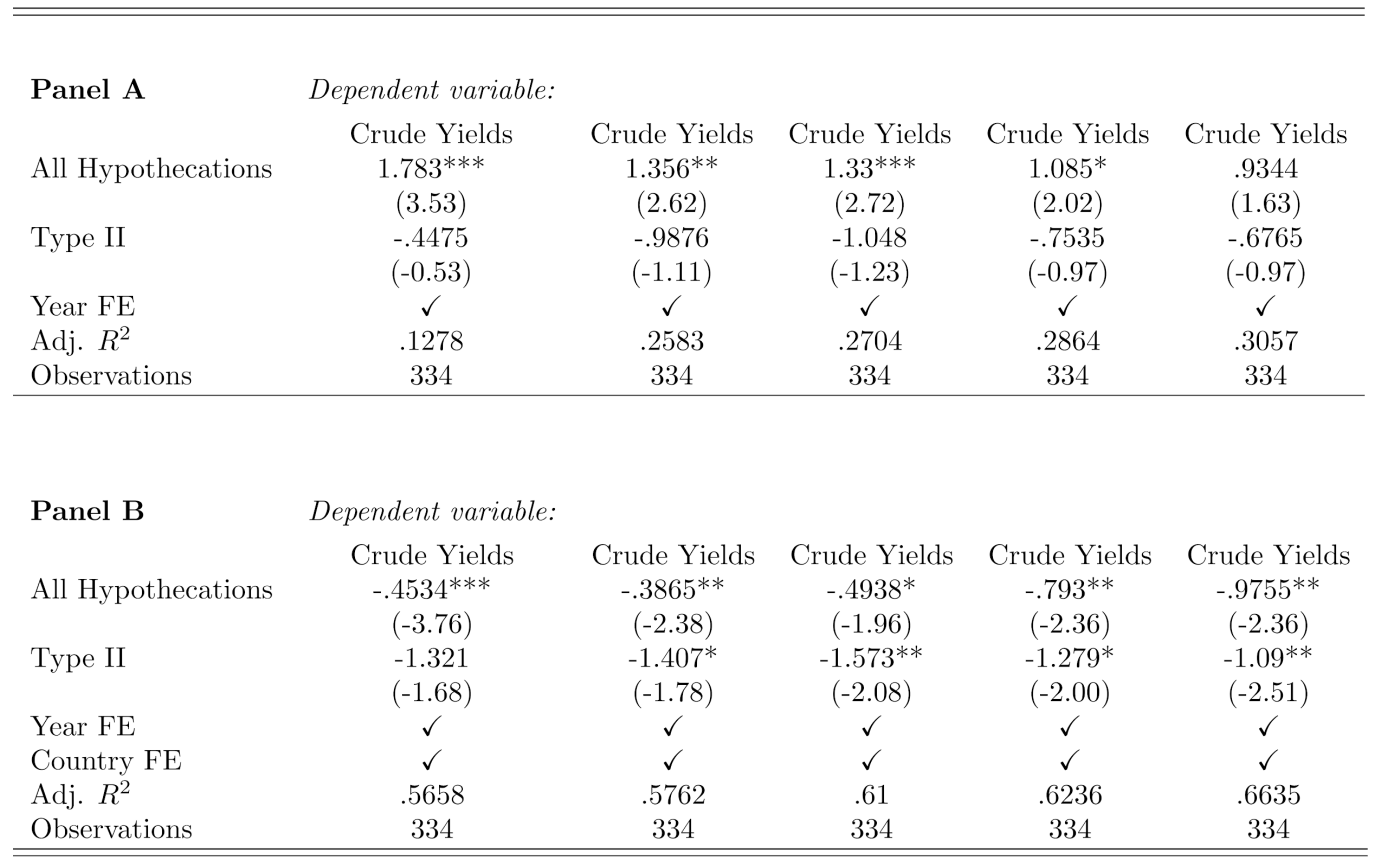

Note: The Table presents results from the estimation of Specification 1, with Panel A reporting the pooled estimates of the correlation between yields and hypothecations, and Panel $\mathbf{B}$ the within estimates; $t$-statistics are in parenthesis. We sequentially include covariates over the different columns. The first column shows estimates that only control for fixed effects and the perpetuity dummy; then, we add the log of the volume of bonds issued; the log of the maturity of the bond; the dummy for the presence of the loan's purpose in the prospect; the dummy for prestigious underwriters. Errors are clustered at the country-vintage of issuance level.

${ }^{*} \mathrm{p}<0.1 ; \quad{ }^{* *} \mathrm{p}<0.05 ; \quad{ }^{* * *} \mathrm{p}<0.01$ 
Table 7: Hypothecations reaction to the 1872 panic

\section{Dependent variable: Yield Spread}

\begin{tabular}{|c|c|c|c|c|}
\hline All Hypothecations & $\begin{array}{c}-2.481 * * * \\
(-3.35)\end{array}$ & & $\begin{array}{c}-1.166^{*} \\
(-1.98)\end{array}$ & \\
\hline Type II & $\begin{array}{l}-.4062 \\
(-0.73)\end{array}$ & & $\begin{array}{l}-.4064 \\
(-0.56)\end{array}$ & \\
\hline Default bond & $\begin{array}{c}2.585^{* * *} \\
(3.07)\end{array}$ & & $\begin{array}{l}.8956 \\
(0.89)\end{array}$ & \\
\hline All, Post & $\begin{array}{c}2.679^{* * * *} \\
(3.42)\end{array}$ & $\begin{array}{c}2.812^{* * *} \\
(3.32)\end{array}$ & $\begin{array}{l}.7205 \\
(1.61)\end{array}$ & $\begin{array}{l}.7087^{*} \\
(1.97)\end{array}$ \\
\hline Type II, Post & $\begin{array}{c}-1.933^{* *} \\
(-2.01)\end{array}$ & $\begin{array}{c}-2.321^{* *} \\
(-2.60)\end{array}$ & $\begin{array}{l}-1.642 \\
(-1.48)\end{array}$ & $\begin{array}{c}-1.983^{*} \\
(-1.96)\end{array}$ \\
\hline Default bond, Post & & & $\begin{array}{c}3.875^{* * *} \\
(3.98)\end{array}$ & $\begin{array}{c}3.889^{* * * *} \\
(4.15)\end{array}$ \\
\hline Country and Year FE & $\checkmark$ & & $\checkmark$ & $\checkmark$ \\
\hline Bond and Year FE & & $\checkmark$ & & $\checkmark$ \\
\hline Adj. $R^{2}$ & .7051 & .7402 & .7284 & .7626 \\
\hline Observations & 766 & 760 & 766 & 760 \\
\hline
\end{tabular}

Note: The Table presents results from the estimation of Specification 5; t-statistics are in parenthesis. We always include dummies for perpetuity, prestigious underwriter, purpose of the project in the prospectus and controls for the log of volume and the log of maturity. Errors are clustered at the country-vintage of issuance level.

${ }^{*} \mathrm{p}<0.1 ;{ }^{* *} \mathrm{p}<0.05 ;{ }^{* * *} \mathrm{p}<0.01$ 


\section{Figures}

Figure 1: Yields did not rise after May 1869
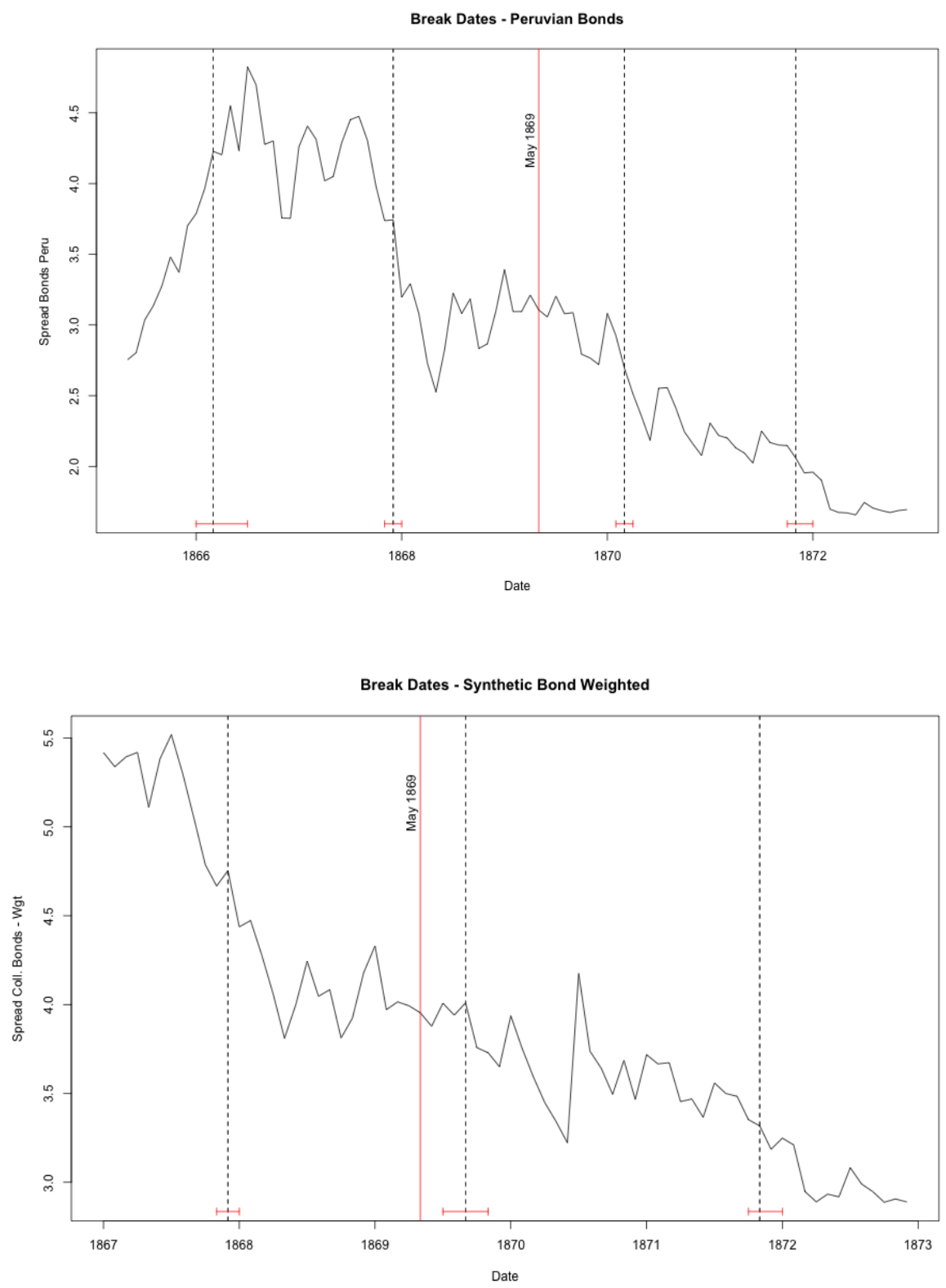

Note: From the top left, the Figure reports the graphical results of performing the structural break test on, first, the Peruvian $18655 \%$ bond's spread series; second, the spread series for the unweighted portfolio composed of the Chilean 6\% 1867 (custom revenues), the Romanian ("Danubian") 7\% 1864 (custom revenues), the Egyptian 7\% 1866 (railways) and the Turkish 6\%1862 (excise on tobacco and salt); third, the spread series for the same portfolio of bonds, weighted for issuance size. Dashed lines represent break dates; red whiskers cover 95\% confidence intervals; the red line tracks the month of Smith v Weguelin's verdict. 


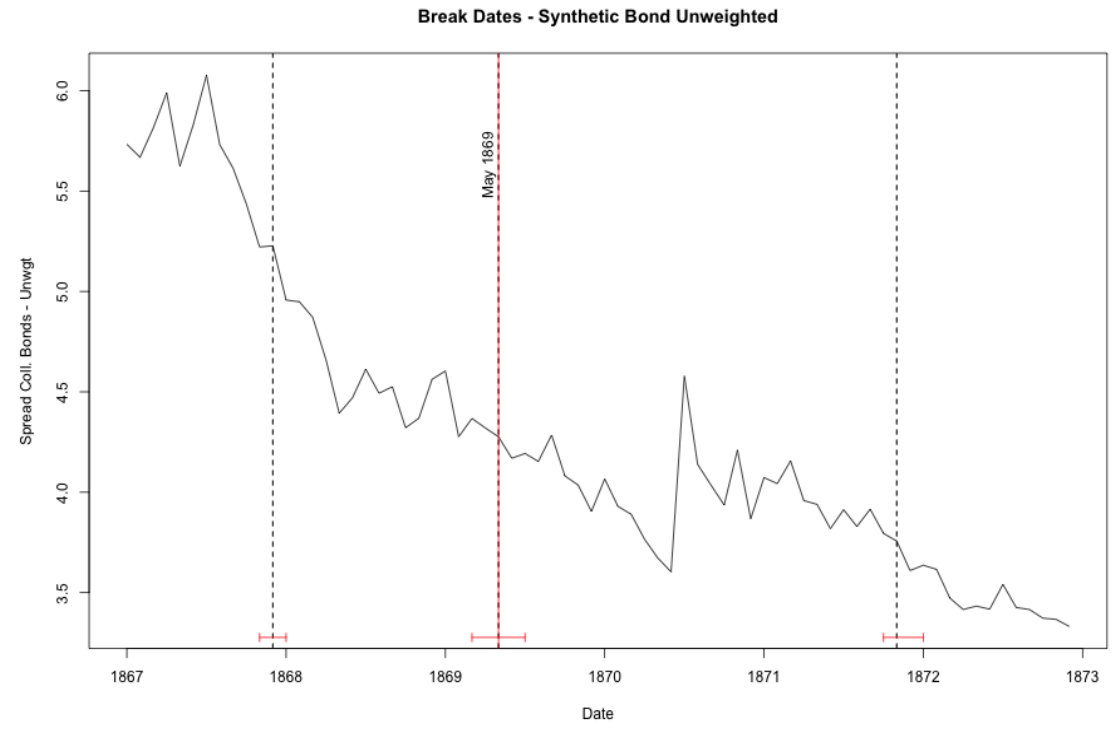


Figure 2: Bond issuance distribution

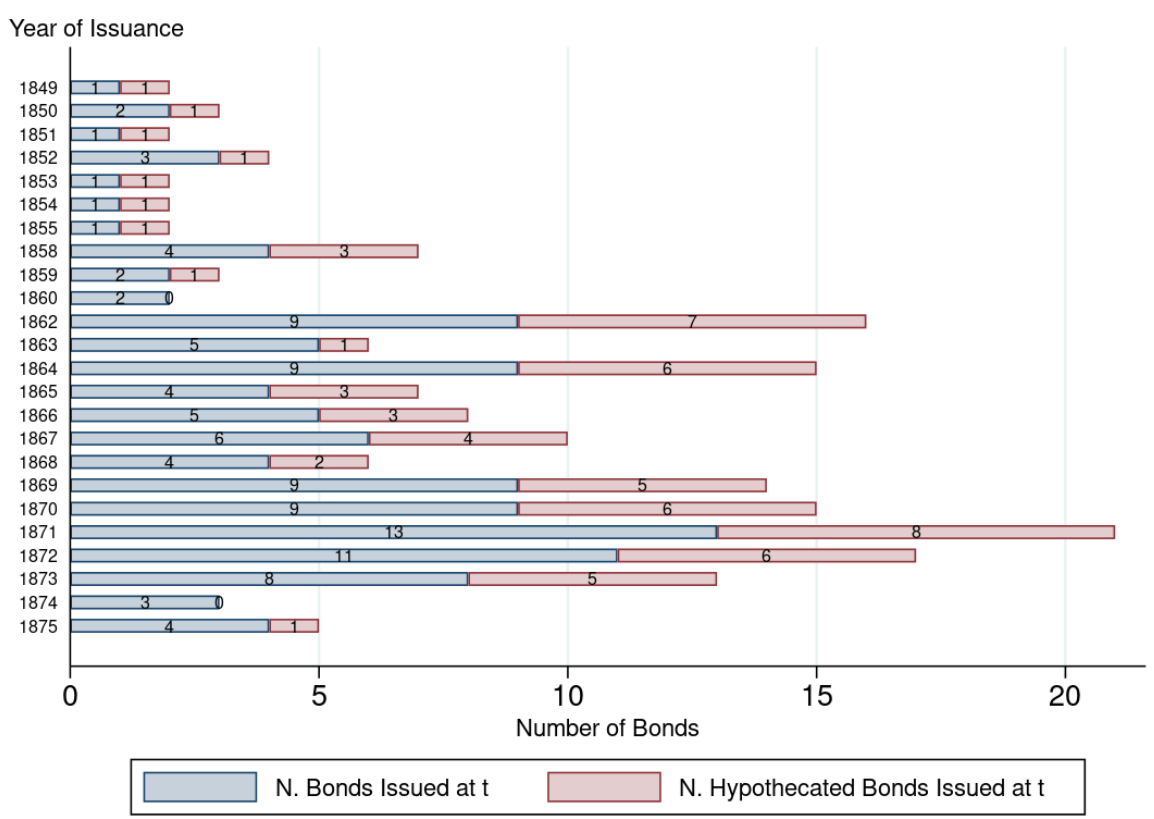

Note: This Figure documents the distribution of bonds over year of issuance, specifying in red the number of bonds including collateral clauses issued each year. 
Figure 3: Collateral clauses description
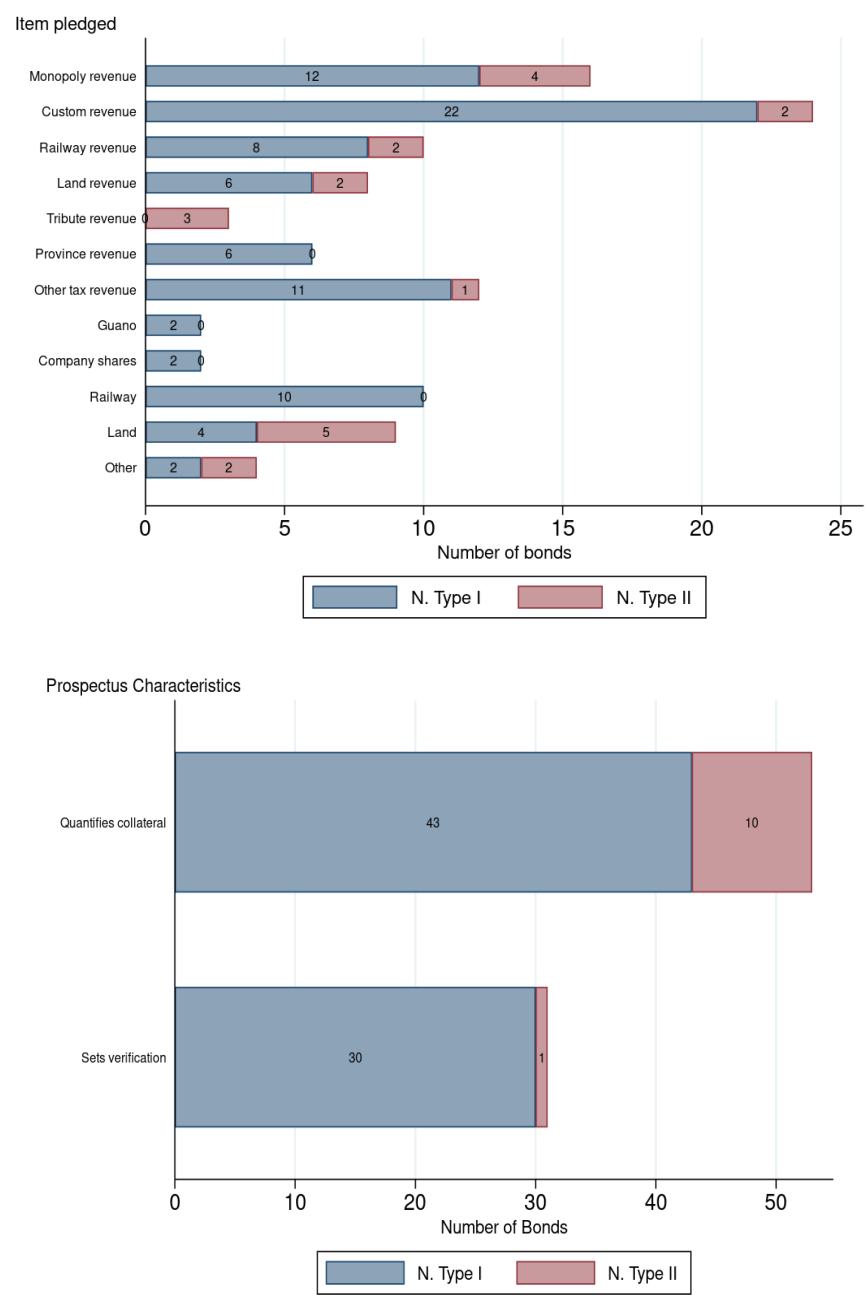

Note: This Figure presents summaries of prospectus characteristics for the sixty-eight hypothecated bonds, separately for Type I and Type II hypothecations. The left bar chart presents the assets pledged. "Other tax revenue" category includes three bonds pledging "octrois" (which were essentially internal customs, taxes on the movement of goods for sale within a state); taxes on the sale of small animals and the manufacture of oil; taxes on liquor and coffee; personal (income) tax; taxes on slaughterhouses; revenues from stamp and licenses; navigation tolls. The "Monopoly revenue" category includes six bonds pledging guano revenues; six bonds pledging tobacco revenues; two bonds pledging revenues from salt; one bond each pledging revenues respectively from coal and mahogany; from mercury; from fish and locks; from a navigation company. The "Other" category includes one bond each pledging respectively a mine, stocks backed by land, a reserve fund and rice. The right bar chart presents further details of the prospectuses, on top and above asset pledged. The "Set verification" category implies that the prospectus either pledged a tradable good, or foresaw bondholders' representative overseeing payment collection, or foresaw British consuls employed by creditors to oversee payment collection. Categories are not mutually exclusive. 
Figure 4: Collateral clauses and transparency

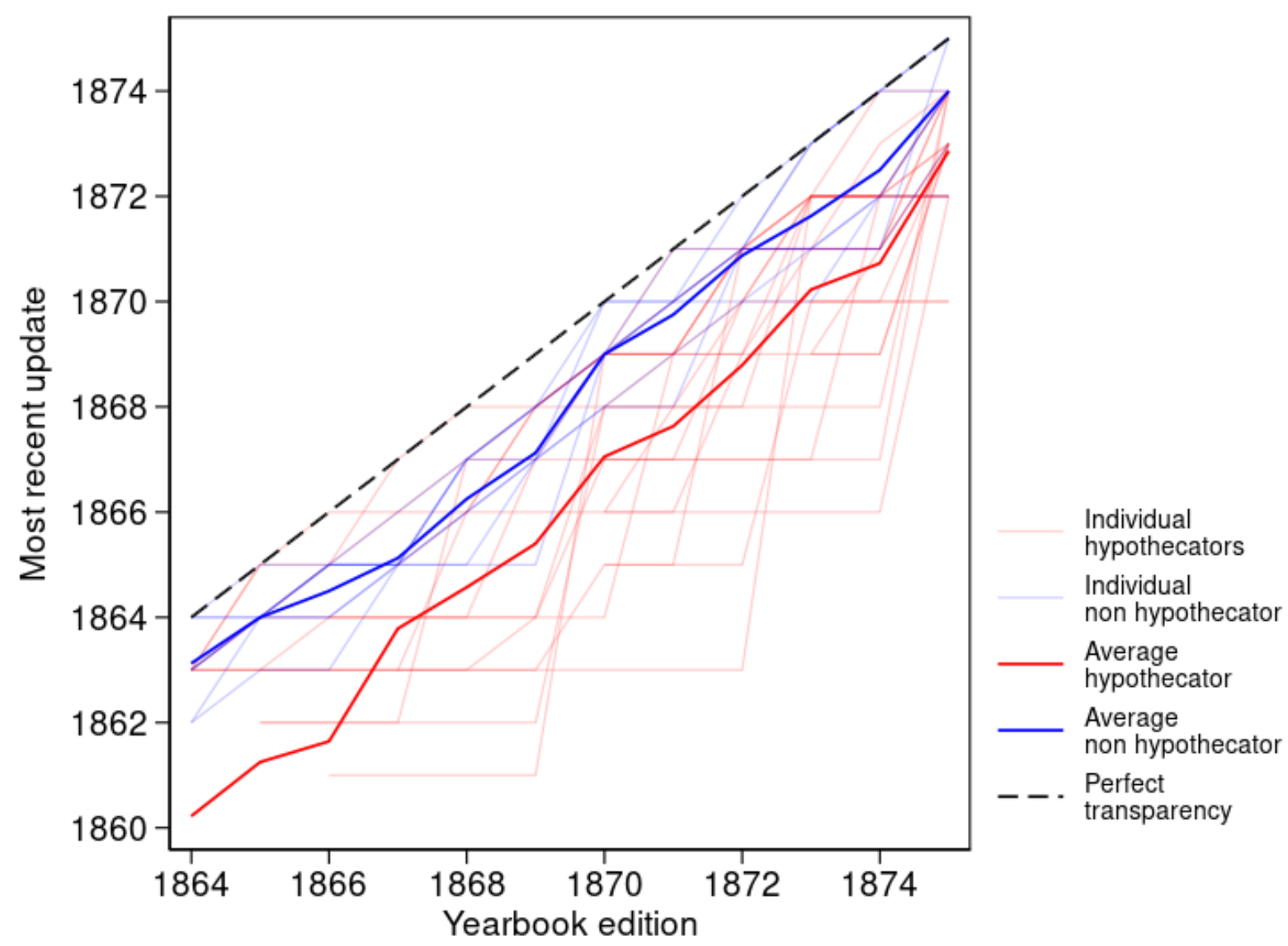

Note: The Figure summarizes the availability of revenue figures in the Statesman Yearbook, distinguishing between sovereigns that issued collateralized bonds (in red) and sovereigns that did not (in blue). On the $x$-axis, we list the year of publishing of each issue of the Yearbook. On the $y$-axis, we list the year of the most recent update for each sovereign revenue figure. We represent perfect transparency by continuously updated and current figures available each year, i.e. the dashed line. 
Figure 5: No case of large, significant reactions to Smith v Weguelin

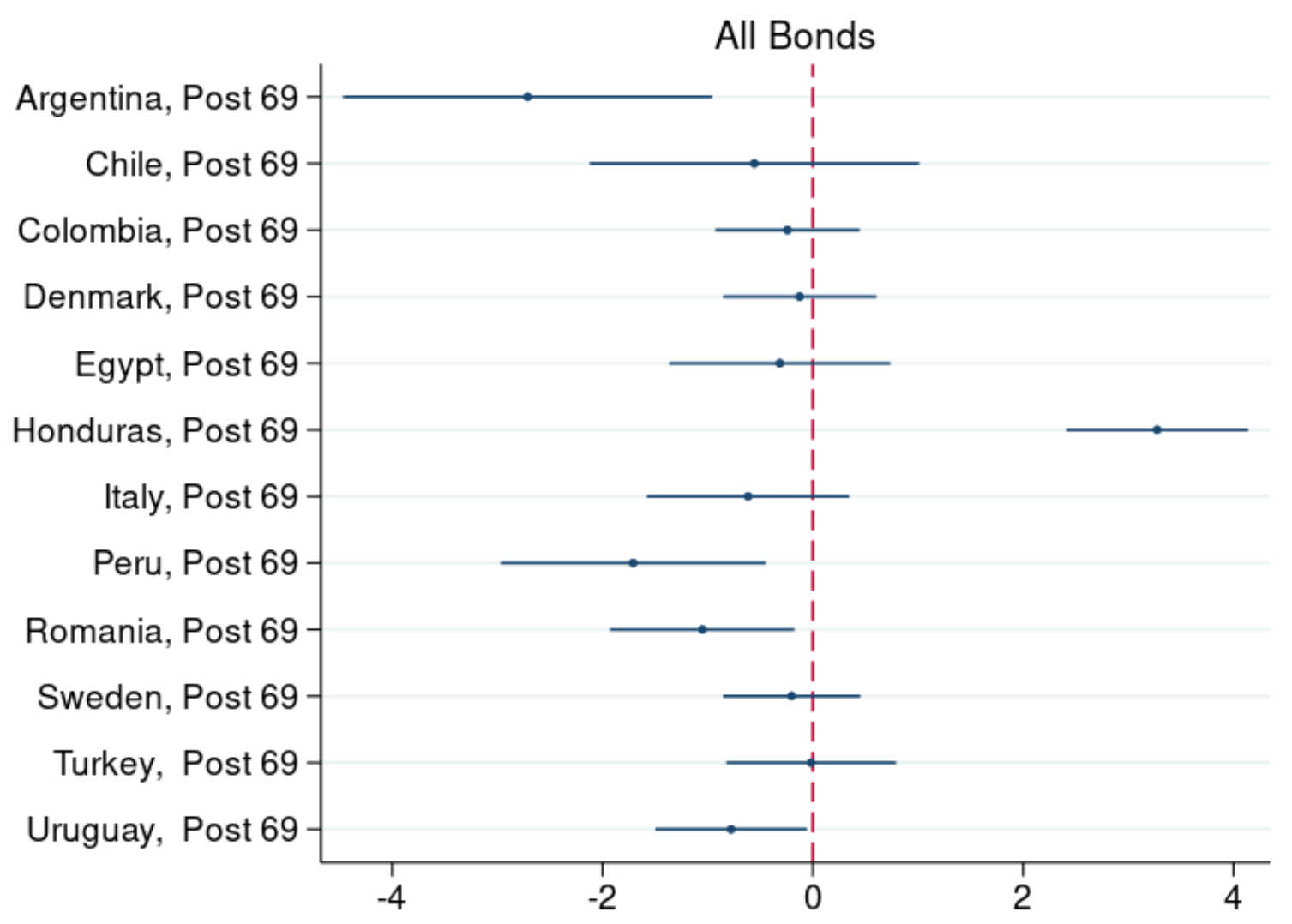

Note: The Figure presents a summary of the components of the ${ }^{\wedge} \mathrm{c}$ vector, resulting from the estimation of Equation 4 with observations up to and including year 1872. Additional controls in the estimating equation are year fixed effects; country fixed effects; dummies for prestigious underwriters, for the mention of loan's purpose in the bond prospectus; the log of issued volume and the log of maturity. Errors are clustered at the countryvintage of issuance level. 
Figure 6: Specification chart for Table 2 - Alternative Maturity cutoffs

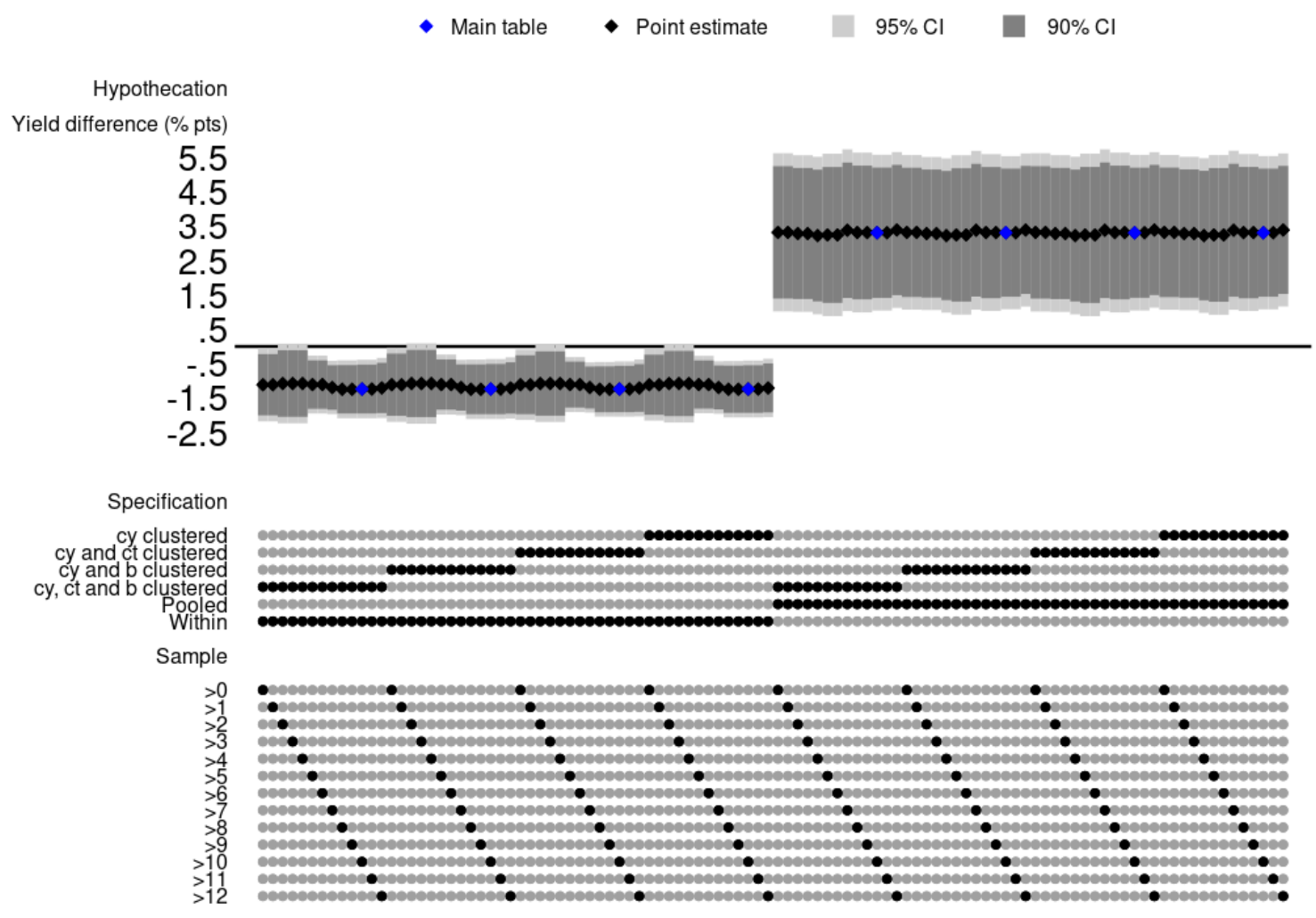

Note: The Figure presents a specification chart for the result in Table 2. We summarize robustness of the standard errors to four alternative clustering schemes (Specification, first four lines) for both the within and the pooled estimates, and robustness of the point estimates and standard errors to progressive inclusion of short term bonds. Blue diamonds mark estimates of $\beta$ and $\beta_{F E}$ for bonds with maturity greater than 10 years (as in Table 2), under different clustering schemes. 
Figure 7: Specification chart for Table 2 - Alternative Type II definitions

- Point estimate $\quad 95 \% \mathrm{Cl} \quad 90 \% \mathrm{Cl}$

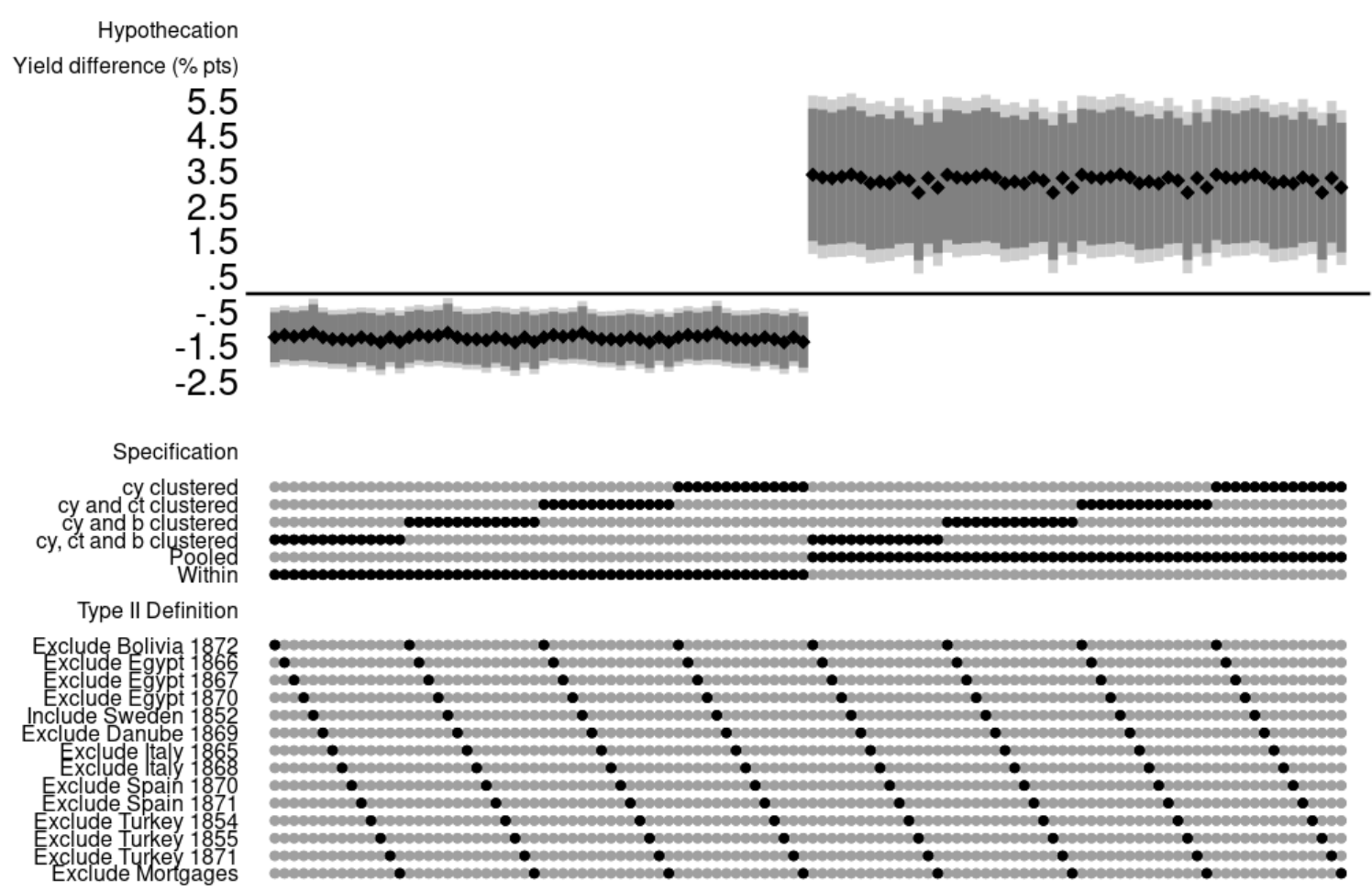

Note: The Figure presents a specification chart for the result in Table 2. We summarize robustness of the standard errors to four alternative clustering schemes (Specification, first four lines) for both the within and the pooled estimates, and robustness of the point estimates and standard errors to alternative definitions of Type II bonds. 
Figure 8: Specification chart for Table 3 - Recent information
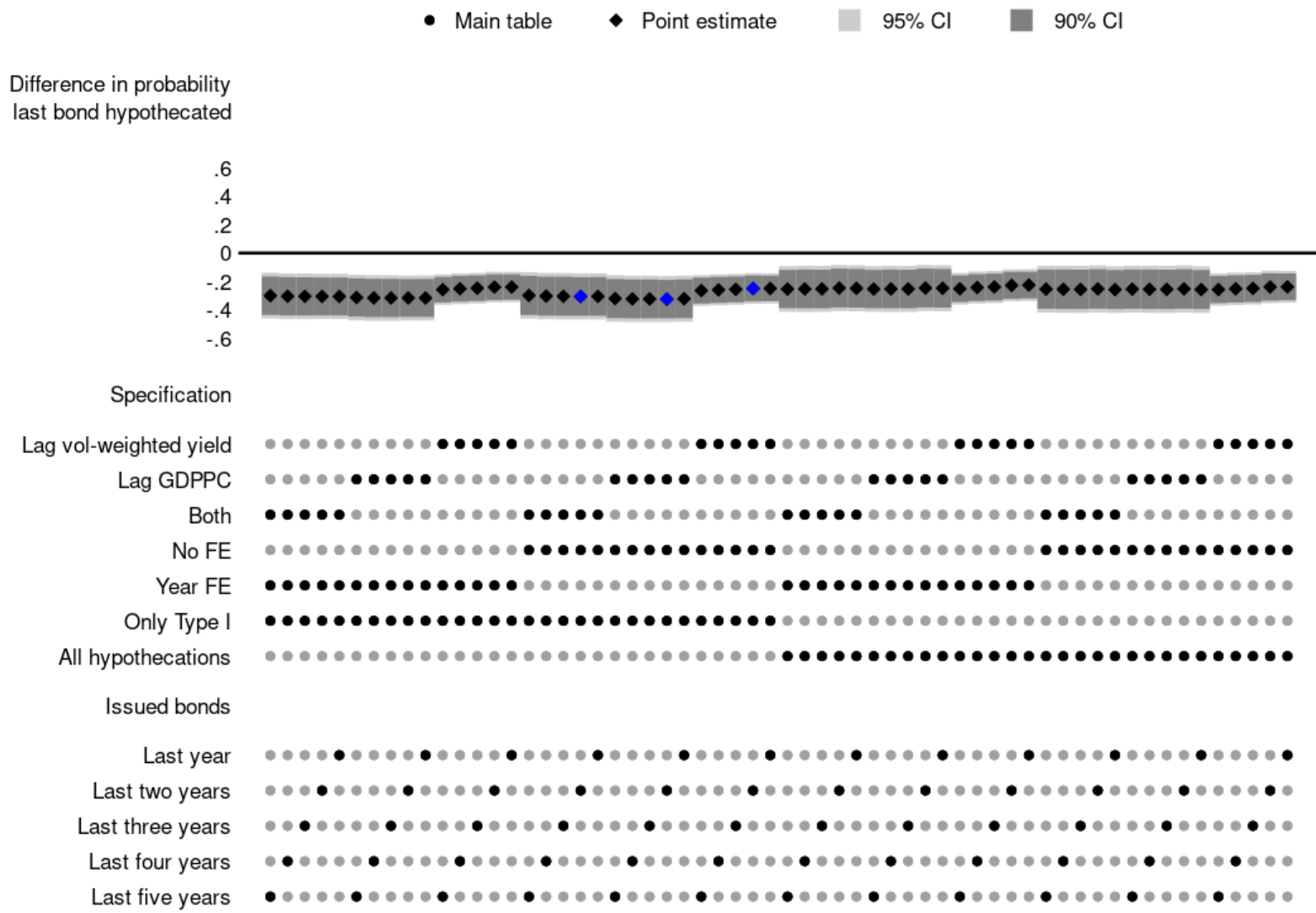

Note: The Figure presents a specification chart for the result in the first panel of Table 3. We summarize robustness of the estimates and standard errors to alternative specifications and alternative controls for previous sovereign's bond-issuing activity. 
Figure 9: Specification chart for Table 3 - Updated information
- Main table
- Point estimate
$95 \% \mathrm{Cl}$
$90 \% \mathrm{Cl}$

Difference in probability last bond hypothecated

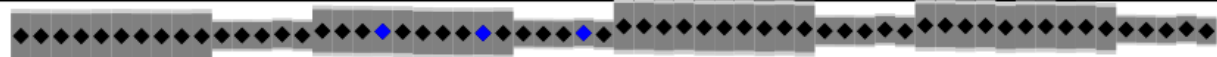

Specification

Lag vol-weighted yield Lag GDPPC

Both

No FE

Year FE

Only Type I

All hypothecations

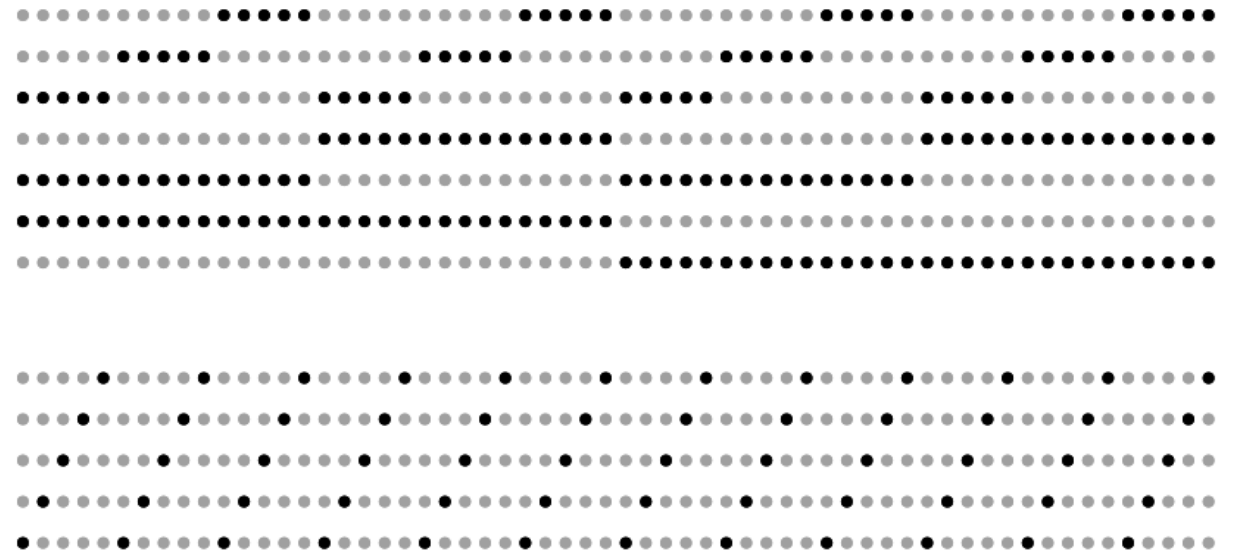

Issued bonds

Last year Last two years Last three years Last four years Last five years

Note: The Figure presents a specification chart for the result in the second panel of Table 3. We summarize robustness of the estimates and standard errors to alternative specifications and alternative controls for previous sovereign's bond-issuing activity. 
Figure 10: Specification chart for Table 3 - Age of information

- Main table

- Point estimate

$95 \% \mathrm{Cl}$

$90 \% \mathrm{Cl}$

Difference in probability

last bond hypothecated

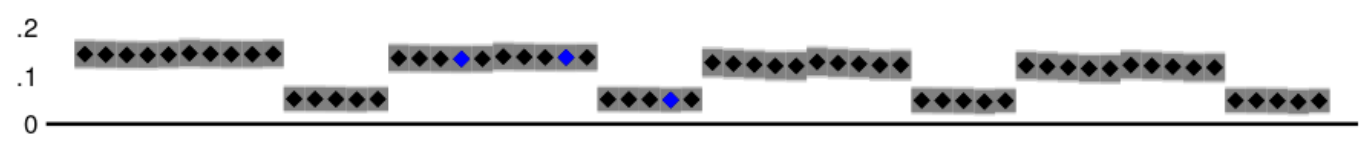

Specification

Lag vol-weighted yield

Lag GDPPC

$\bullet \bullet \bullet \bullet \bullet \bullet \bullet \bullet \bullet \bullet \bullet \bullet \bullet \bullet \bullet \bullet \bullet \bullet \bullet \bullet \bullet \bullet \bullet \bullet \bullet \bullet \bullet \bullet \bullet \bullet \bullet \bullet \bullet \bullet \bullet \bullet \bullet \bullet \bullet \bullet \bullet \bullet \bullet \bullet \bullet \bullet \bullet \bullet \bullet \bullet \bullet \bullet \bullet \bullet \bullet \bullet \bullet \bullet \bullet \bullet$

$\bullet \bullet \bullet \bullet \bullet \bullet \bullet \bullet \bullet \bullet \bullet \bullet \bullet \bullet \bullet \bullet \bullet \bullet \bullet \bullet \bullet \bullet \bullet \bullet \bullet \bullet \bullet \bullet \bullet \bullet \bullet \bullet \bullet \bullet \bullet \bullet \bullet \bullet \bullet \bullet \bullet \bullet \bullet \bullet \bullet \bullet \bullet \bullet \bullet \bullet \bullet \bullet \bullet \bullet \bullet \bullet \bullet \bullet \bullet \bullet$

Both

$\bullet \bullet \bullet \bullet \bullet \bullet \bullet \bullet \bullet \bullet \bullet \bullet \bullet \bullet \bullet \bullet \bullet \bullet \bullet \bullet \bullet \bullet \bullet \bullet \bullet \bullet \bullet \bullet \bullet \bullet \bullet \bullet \bullet \bullet \bullet \bullet \bullet \bullet \bullet \bullet \bullet \bullet \bullet \bullet \bullet \bullet \bullet \bullet \bullet \bullet \bullet \bullet \bullet \bullet \bullet \bullet \bullet \bullet \bullet \bullet$

No FE

$\bullet \bullet \bullet \bullet \bullet \bullet \bullet \bullet \bullet \bullet \bullet \bullet \bullet \bullet \bullet \bullet \bullet \bullet \bullet \bullet \bullet \bullet \bullet \bullet \bullet \bullet \bullet \bullet \bullet \bullet \bullet \bullet \bullet \bullet \bullet \bullet \bullet \bullet \bullet \bullet \bullet \bullet \bullet \bullet \bullet \bullet \bullet \bullet \bullet \bullet \bullet \bullet \bullet \bullet \bullet \bullet \bullet \bullet \bullet \bullet$

Year FE

$\bullet \bullet \bullet \bullet \bullet \bullet \bullet \bullet \bullet \bullet \bullet \bullet \bullet \bullet \bullet \bullet \bullet \bullet \bullet \bullet \bullet \bullet \bullet \bullet \bullet \bullet \bullet \bullet \bullet \bullet \bullet \bullet \bullet \bullet \bullet \bullet \bullet \bullet \bullet \bullet \bullet \bullet \bullet \bullet \bullet \bullet \bullet \bullet \bullet \bullet \bullet \bullet \bullet \bullet \bullet \bullet \bullet \bullet \bullet \bullet$

Only Type I

$\bullet \bullet \bullet \bullet \bullet \bullet \bullet \bullet \bullet \bullet \bullet \bullet \bullet \bullet \bullet \bullet \bullet \bullet \bullet \bullet \bullet \bullet \bullet \bullet \bullet \bullet \bullet \bullet \bullet \bullet \bullet \bullet \bullet \bullet \bullet \bullet \bullet \bullet \bullet \bullet \bullet \bullet \bullet \bullet \bullet \bullet \bullet \bullet \bullet \bullet \bullet \bullet \bullet \bullet \bullet \bullet \bullet \bullet \bullet \bullet$

All hypothecations

$\bullet \bullet \bullet \bullet \bullet \bullet \bullet \bullet \bullet \bullet \bullet \bullet \bullet \bullet \bullet \bullet \bullet \bullet \bullet \bullet \bullet \bullet \bullet \bullet \bullet \bullet \bullet \bullet \bullet \bullet$

Issued bonds
Last year
Last two years
Last three years
Last four years
Last five years

$\bullet \bullet \bullet \bullet \bullet \bullet \bullet \bullet \bullet \bullet \bullet \bullet \bullet \bullet \bullet \bullet \bullet \bullet \bullet \bullet \bullet \bullet \bullet \bullet \bullet \bullet \bullet \bullet \bullet \bullet \bullet \bullet \bullet \bullet \bullet \bullet \bullet \bullet \bullet \bullet \bullet \bullet \bullet \bullet \bullet \bullet \bullet \bullet \bullet \bullet \bullet \bullet \bullet \bullet \bullet \bullet \bullet \bullet \bullet \bullet$

$\bullet \bullet \bullet \bullet \bullet \bullet \bullet \bullet \bullet \bullet \bullet \bullet \bullet \bullet \bullet \bullet \bullet \bullet \bullet \bullet \bullet \bullet \bullet \bullet \bullet \bullet \bullet \bullet \bullet \bullet \bullet \bullet \bullet \bullet \bullet \bullet \bullet \bullet \bullet \bullet \bullet \bullet \bullet \bullet \bullet \bullet \bullet \bullet \bullet \bullet \bullet \bullet \bullet \bullet \bullet \bullet \bullet \bullet \bullet \bullet$

$\bullet \bullet \bullet \bullet \bullet \bullet \bullet \bullet \bullet \bullet \bullet \bullet \bullet \bullet \bullet \bullet \bullet \bullet \bullet \bullet \bullet \bullet \bullet \bullet \bullet \bullet \bullet \bullet \bullet \bullet \bullet \bullet \bullet \bullet \bullet \bullet \bullet \bullet \bullet \bullet \bullet \bullet \bullet \bullet \bullet \bullet \bullet \bullet \bullet \bullet \bullet \bullet \bullet \bullet \bullet \bullet \bullet \bullet \bullet \bullet$

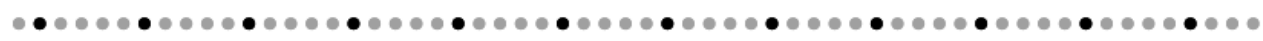

$\bullet \bullet \bullet \bullet \bullet \bullet \bullet \bullet \bullet \bullet \bullet \bullet \bullet \bullet \bullet \bullet \bullet \bullet \bullet \bullet \bullet \bullet \bullet \bullet \bullet \bullet \bullet \bullet \bullet \bullet \bullet \bullet \bullet \bullet \bullet \bullet \bullet \bullet \bullet \bullet \bullet \bullet \bullet \bullet \bullet \bullet \bullet \bullet \bullet \bullet \bullet \bullet \bullet \bullet \bullet \bullet \bullet \bullet \bullet \bullet$

Note: The Figure presents a specification chart for the result in the third panel of Table 3 . We summarize robustness of the estimates and standard errors to alternative specifications and alternative controls for previous sovereign's bond-issuing activity. 
Figure 11: Specification chart for Table 4 - Prestigious underwriters

- Point estimate $\quad 95 \% \mathrm{Cl} \quad 90 \% \mathrm{Cl}$

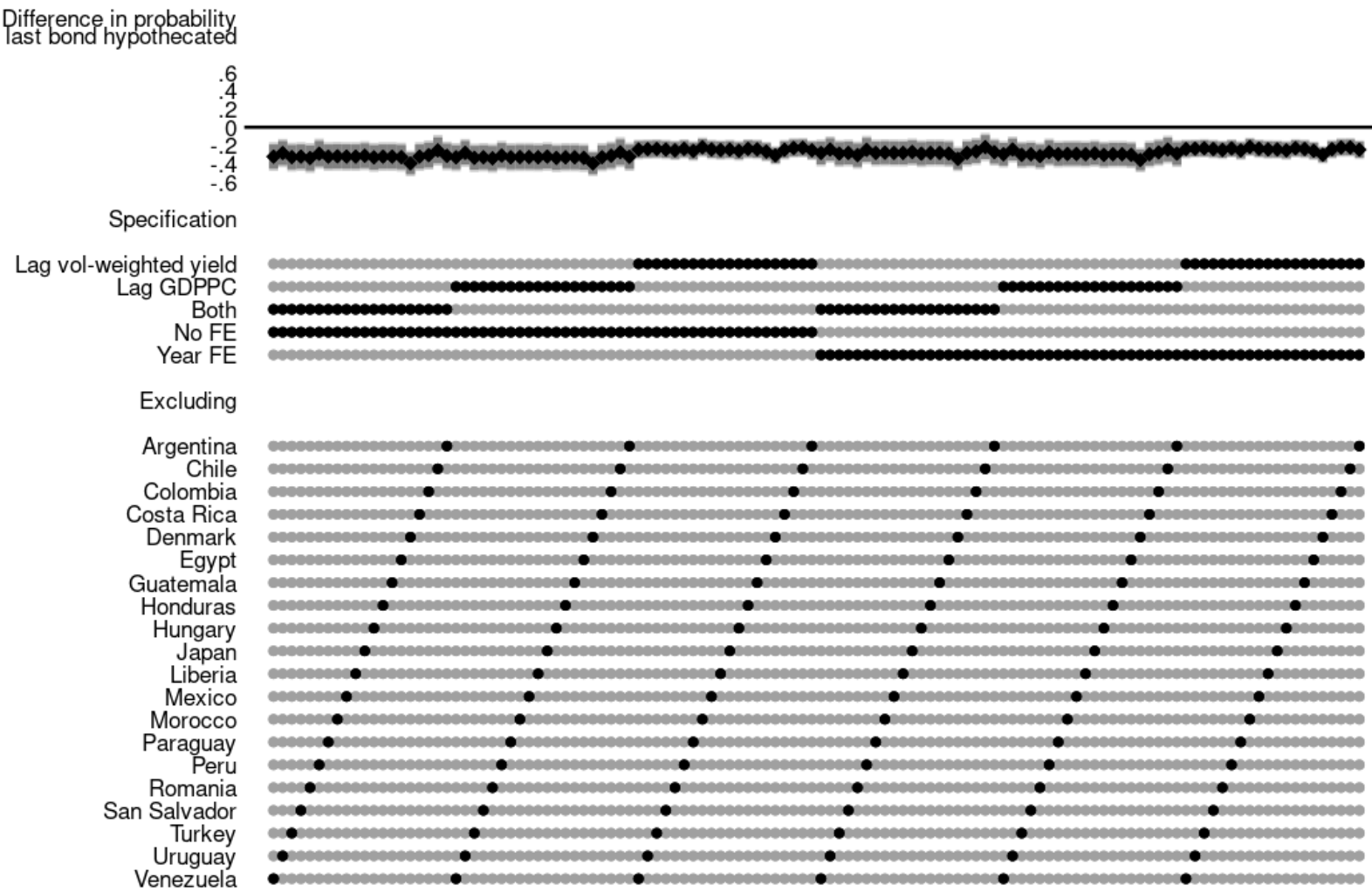

Note: The Figure presents a specification chart for the result in the third panel of Table 4 . We summarize robustness of the estimates and standard errors to alternative specifications and alternative controls for previous sovereign's bond-issuing activity 
Figure 12: The 1872 panic

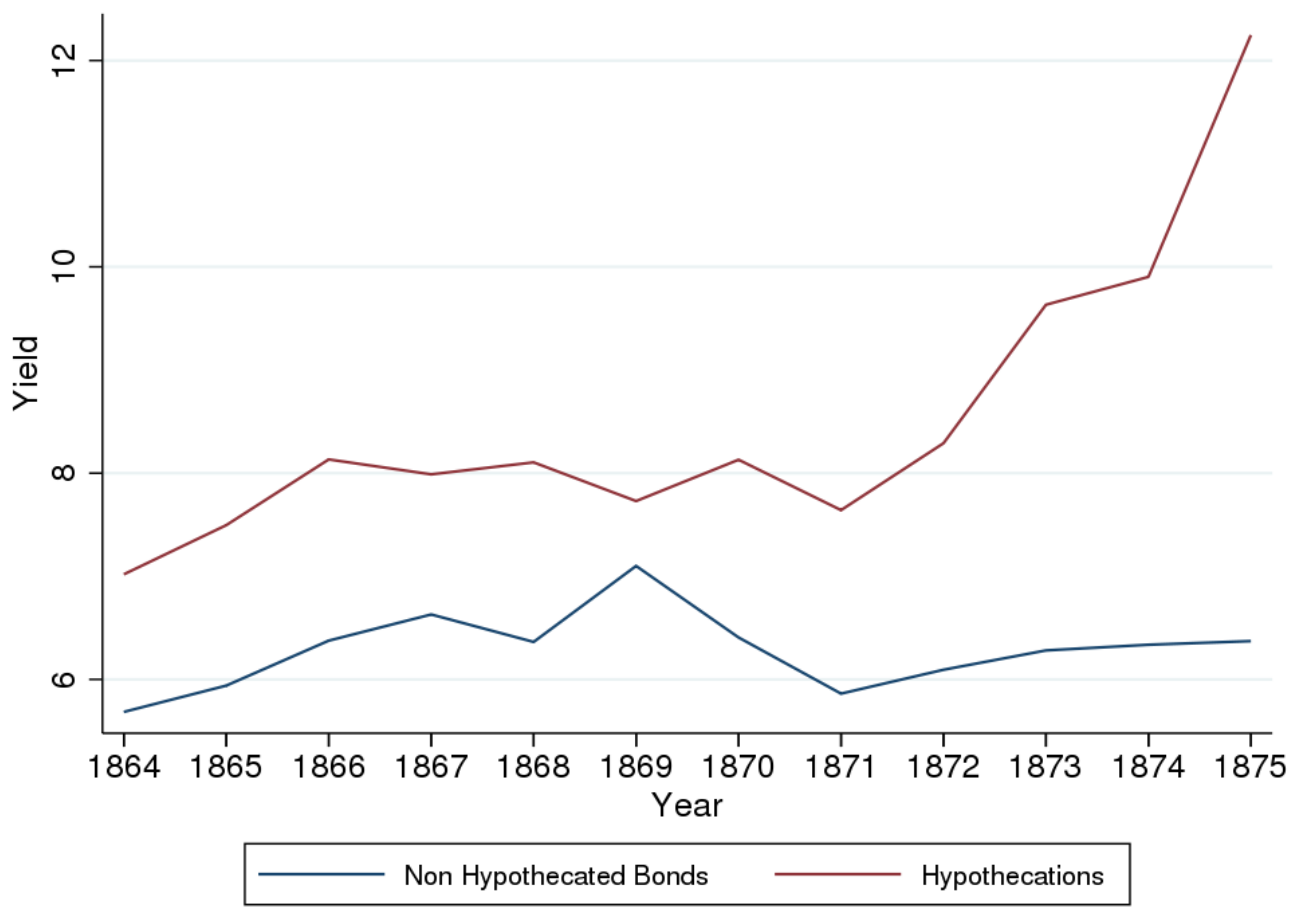

Note: The Figure presents the behavior of yields for hypothecated and non-hypothecated bonds. Yields-tomaturity, on the $y$-axis, are in percentage points. 


\section{References}

Aghion, Philippe and Patrick Bolton. 1997. "A theory of trickle down growth and development" Review of Economic Studies, 64 (2): 151-172.

Al, Huseyin. 2012. "Was there a guarantee effect for the Ottoman loans in the $19^{\text {th }}$-century?" Australian Economic History Review, 52 (2): 191-208.

Ayres, Henry. 1857. Ayres's financial register of British and foreign funds, banks, etc., etc., for 1857, etc. London: Richardson Brothers.

Anderson, Olive. 1964. "Great Britain and the Beginnings of the Ottoman Public Debt, 1854-55," The Historical Journal, 7 (1): 47-63

Anonymous. 1865. Vendita di beni demaniali, Firenze: Stamperia Reale.

Anonymous. 1873. Papers and Documents Relation to the Bolivian Loan. London: Dunlop.

Bai, Jushan and Pierre Perron. 1998. "Estimating and testing linear models with multiple structural changes." Econometrica: 47-78.

- 2003. "Computation and analysis of multiple structural change models." Journal of Applied Econometrics, 18 (1): 1-22.

Baron, Matthew and Wei Xiong. 2017. "Credit expansion and neglected crash risk.” The Quarterly Journal of Economics 132 (2): 713-764.

Barron, Daniel and Yingni Guo. 2021. "The use and misuse of coordinated punishments." The Quarterly Journal of Economics, 136 (1): 471-504.

Berger, Allen N., Marco A. Espinosa-Vega, W. Scott Frame, and Nathan H. Miller. 2011. "Why do borrowers pledge collateral? New empirical evidence on the role of asymmetric information." Journal of Financial Intermediation, 20 (1):55-70.

Berger, Allen N., W. Scott Frame, and Vasso Ioannidou. 2011. "Tests of ex ante versus ex post theories of collateral using private and public information." Journal of Financial Economics, 100 (1): 85-97.

Bernanke, Ben S. and Mark Gertler. 1989. "Agency Costs, Net Worth, and Business Fluctuations." American Economic Review, 79 (1):14-31.

Besanko, David and Anjan V. Thakor. 1987. "Collateral and rationing: sorting equilibria in monopolistic and competitive credit markets." International Economic Review: 671- 689.

. 1987. "Competitive equilibrium in the credit market under asymmetric information." Journal of Economic Theory, 42 (1): 167-183

Bester, Helmut 1985. "Screening vs. rationing in credit markets with imperfect information". The American economic review, 75 (4): 850-855.

Bolt, Jutta and Jan L. van Zanden. 2020. "Maddison Style Estimates of the Evolution of the World Economy. A New 2020 Update." University of Groningen, Groningen Growth and Development Centre, Maddison Project Working Paper (15).

Boot, Arnoud W. A. and Anjan V. Thakor. 1994. "Moral hazard and secured lending in an infinitely repeated credit market game". 1994. International Economic Review, 35: 899-920 
Boot, Arnoud W. A., Anjan V. Thakor and G.F. Udell. 1991. "Secured lending and default risk: equilibrium analysis, policy implications and empirical results". Economic Journal, 101 (406): 458-472.

Borchard, Edwin. 1951. State insolvency and foreign bondholders. 1. General principles. Yale University Press.

Bordalo, Pedro, Nicola Gennaioli, and Andrei Shleifer. 2012. "Salience theory of choice under risk." The Quarterly Journal of Economics, 127 (3):1243-1285.

Börner, Lars and John William Hatfield. 2017. "The design of debt-clearing markets: Clearinghouse mechanisms in preindustrial Europe." Journal of Political Economy, 125 (6):19912037.

Bradley, Michael, and Michael R. Roberts. 2015. "The structure and pricing of corporate debt covenants." The Quarterly Journal of Finance, 5 (2): 1550001.

Bräutigam, Deborah and Kevin P. Gallagher. 2014. "Bartering globalization: China's commoditybacked finance in Africa and Latin America." Global Policy, 5 (3):346-352.

Buchheit, Lee C., and Jeremiah S. Pam. 2004. "The pari passu clause in sovereign debt instruments." Emory Law Journal, 53 (869).

Butler, Alexander W., Larry Fauver, and Sandra Mortal. 2009. "Corruption, political connections, and municipal finance." The Review of Financial Studies, 22 (7):2873-2905.

Calomiris, Charles W, Mauricio Larrain, José Liberti, and Jason Sturgess. 2017. "How collateral laws shape lending and sectoral activity." Journal of Financial Economics, 123 (1):163-188.

Cauwès, P. 1895a. "Commencements du crédit public en France. Les rentes sur 1'Hôtel-de-Ville au XVIème siècle (1522-1547)." Revue d'Economie Politique, 9 : 97-123.

Cauwès, P. 1895b. "Commencements du crédit public en France. Les rentes sur 1'Hôtel-de-Ville de Paris au XVIème siècle (1547 à 1561)." Revue d'Economie Politique, 9: 825-865.

Cauwès, P. 1896. "Commencements du crédit public en France. Les rentes sur 1'Hôtel-de-Ville au XVIème siècle (1561 à 1588)." Revue d'Economie Politique, 10: 411-479.

Ceci, Antonio. 2015. "Il monopolio del tabacco in Italia Ascesa e declino di una industria di Stato." Historia et ius, $\mathrm{n}^{\circ}$ 8, December, Paper 16

Cerqueiro, Geraldo, Steven Ongena, and Kasper Roszbach. 2016. "Collateralization, bank loan rates, and monitoring." The Journal of Finance, 71 (3):1295-1322.

Chabot, Benjamin and Veronica Santarosa. 2017. "Don't cry for Argentina (or other Sovereign borrowers): Lessons from a previous era of sovereign debt contract enforcement." Capital Markets Law Journal, 12 (1):9-37.

Chan, Yuk-Sheen and Anjan V. Thakor. 1987. "Collateral and competitive equilibria with moral hazard and private information”. Journal of Finance, 42 (2): 345-363

Chava, Sudheer, Praveen Kumar, and Arthur Warga. 2010. "Managerial agency and bond covenants." The Review of Financial Studies, 23 (3): 1120-1148.

Chavaz, Matthieu and Marc Flandreau. 2017. "“High \& dry": the liquidity and credit of colonial and foreign government debt and the London Stock Exchange (1880-1910)." The Journal of 
Economic History, 77 (3): 653-691.

Chemmanur, Thomas J. and Paolo Fulghieri. 1994. "Investment bank reputation, information production, and financial intermediation." The Journal of Finance, 49 (1):57-79.

Chitty, Joseph. 1841. A Practical Treatise on the Law of Contracts. London: Sweet. Clarke, Hyde. 1859. "Memoir of Sir Isaac Goldsmid.” Banker's Magazine, (July):449-57.

Cohen, Lionel L. 1876. "Foreign loans: Their introduction to the public, and admission to the stock exchange in connection with the recent report of the committee on foreign loans." In Transactions of the National Association for the Promotion of Social Science, Brighton Meeting, edited by Charles W. Ryalls. National Association for the Promotion of Social Science, 691.

Coleman, Raymond W. 1936. "Pledged Revenue as Security for Government Bonds." The American Economic Review, 26 (4): 667-682.

Council of Foreign Bondholders. 1878. Fifth annual General Report of the Council of the Corporation of Foreign Bondholders for the Year 1877. London: Corporation of Foreign Bondholders.

Dang, Tri Vi, Gary Gorton, Bengt Holmström, and Guillermo Ordonez. 2017. "Banks as secret keepers." American Economic Review, 107 (4):1005-29.

Daniel, Kent, David Hirshleifer, and Siew Hong Teoh. 2002. "Investor psychology in capital markets: Evidence and policy implications.” Journal of Monetary Economics, 49 (1):139-209.

Daru, Pierre. 1821. Histoire de la Republique de Venise, Paris, F. Didot, 2 vols.

Degryse, Hans, Vasso Ioannidou, José María Liberti, and Jason Sturgess. 2020. "How Do Laws and Institutions Affect Recovery Rates for Collateral?" The Review of Corporate Finance Studies, $9(1): 1-43$.

Demarzo, Peter M. 2019. "Presidential address: Collateral and commitment." The Journal of Finance, 74 (4):1587-1619.

Dewey, David R. 1934. Financial History of the United States, New York: Longmans.

Diamond, Douglas W. 1989. "Reputation acquisition in debt markets." Journal of Political Economy, 97 (4):828-862.

Dyson, Kenneth. 2014. States, Debt, and Power. "Saints and "Sinners" in European History and Integration. Oxford: Oxford University Press.

Djankov, Simeon, Rafael La Porta, Florencio Lopez-de Silanes, and Andrei Shleifer. 2003. "Courts." The Quarterly Journal of Economics, 118 (2):453-517.

Donaldson, Jason Roderick, Denis Gromb, and Giorgia Piacentino. 2020. "The paradox of pledgeability." Journal of Financial Economics, 137 (3):591-605.

Du Velay, A. 1903. "Essai sur l'histoire financière de la Turquie : depuis le règne du sultan Mahmoud II jusqu'à nos jours". Paris: A. Rousseau.

Eichengreen, Barry, (1994) "Financing infrastructure in developing countries: lessons from the Railway Age". Working Paper Series, 1379. World Bank Policy Research Paper.

Esteves, Rui P. and Ali Coşkun Tunçer. 2016. "Eurobonds Past and Present: A Comparative Review on Debt Mutualization in Europe." Review of Law \& Economics, 12(3): 659-688 
European Commission. 2010. "Report on Greek government deficit and debt statistics.” Tech. rep. URL https:/ec.europa.eu/eurostat/documents/4187653/6404656/COM_2010_report_greek.

Fenn, Charles. 1855. Compendium of the English and Foreign Funds. London: Effingham Wilson.

Fishlow, Albert. 1985. "Lessons from the past: Capital markets during the 19th century and the interwar period.” International Organization, 39 (3):383-439.

Flandreau, Marc. 2003. "Caveat Emptor-Coping with Sovereign Risk under the International Gold Standard, 1871-1913." In The International Financial History in the Twentieth Century: System and Anarchy. Cambridge, 17-50.

. 2016. Anthropologists in the stock exchange: a financial history of Victorian science. University of Chicago Press.

- 2021. "What is in a Bond? The Value of Portugal or the Financial Origins of the Portuguese Civil War." In Economic Globalization and Governance, edited by Maria E. Mata, Miguel Rocha de Sousa, and Luis Brites Pereira. Springer, 35-50.

Flandreau, Marc, Jacques Le Cacheux, and Frédéric Zumer. 1998. "Stability without a pact? Lessons from the European gold standard, 1880-1914.” Economic Policy, 13 (26):116-162.

Flandreau, Marc and Juan H. Flores. 2009. "Bonds and brands: Foundations of sovereign debt markets, 1820-1830." The Journal of Economic History 69 (3):646-684.

- 2012. "Bondholders versus bond-sellers? Investment banks and conditionality lending in the London market for foreign government debt, 1815-1913." European Review of Economic History 16 (4):356-383.

Flandreau, Marc and Frederic Zumer. 2004. The making of global finance. Paris: OECD.

Fratianni, Michele, and Franco Spinelli. 2006. "Italian city-states and financial evolution." European Review of Economic History, 10 (3): 257-278.Gambacorta, Leonardo, Yiping Huang, Zenhua Li, Han Qiu, and Shu Chen. 2019. "Data vs Collateral”. No. 881. BIS Working Paper.

Garleanu, Nicolae, and Jeffrey Zwiebel. 2009. "Design and renegotiation of debt covenants". The Review of Financial Studies, 22 (2): 749-781.

Gao, Pengjie, Chang Lee, and Dermot Murphy. 2019. "Municipal borrowing costs and state policies for distressed municipalities." Journal of Financial Economics 132 (2):404-426.

Gelpern, Anna, Sebastian Horn, Scott Morris, Brad Parks, and Cristoph Trebesch. 2021. "How China Lends: A Rare Look into 100 Debt Contracts with Foreign Governments”. No. DP16331. CEPR Working Paper.

Gennaioli, Nicola, Andrei Shleifer, and Robert Vishny. 2012. "Neglected risks, financial innovation, and financial fragility." Journal of Financial Economics, 104 (3):452-468.

Gorton, Gary. 2017. "The history and economics of safe assets." Annual Review of Economics, 9:547-586.

Gorton, Gary and Guillermo Ordonez. 2014. "Collateral crises." American Economic Review, 104 (2):343-78.

Gorton, Gary and Guillermo Ordoñez. 2020. "Fighting crises with secrecy." American Economic Journal: Macroeconomics, 12 (4):218-45. 
Greif, Avner. 1992. "Institutions and international trade: Lessons from the commercial revolution." The American Economic Review, 82 (2):128-133.

Greif, Avner, Paul Milgrom, and Barry R. Weingast. 1994. "Coordination, commitment, and enforcement: The case of the merchant guild." Journal of Political Economy, 102 (4):745-776.

Hart, Oliver and John Moore. 2008. "Contracts as reference points." The Quarterly Journal of Economics, 123 (1):1-48.

Hirshleifer, David. 2015. "Behavioral finance." Annual Review of Financial Economics, 7:133159.

Hirst, F. W. 1910. The Credit of Nations, U. S. Senate, 61st Congress, 2nd Session, Document No. 579.

Herslet, Lewis. 1874. British and Foreign State Papers, vol. 59, London: W. Ridgway.

Holmström, Bengt and Jean Tirole. 1997. "Financial intermediation, loanable funds, and the real sector." The Quarterly Journal of Economics, 112 (3):663-691.

Hoyle, Mark S. W. 1986. "The origins of the Mixed Courts of Egypt." Arab Law Quarterly, 1 (2): 220-230.

1987. “The Mixed Courts of Egypt 1896-1905.” Arab Law Quarterly, 2 (1): 57-74.

Horn, Sebastian, Carmen M. Reinhart, and Christoph Trebesch. 2019. China's overseas lending. No. w26050. National Bureau of Economic Research.

Ito, Seiichiro. 2013. "Registration and credit in seventeenth-century England." Financial History Review, 20 (2): 137-162.

IMF/World Bank. 2020. Collateralized Transactions: Key Considerations for Public Lenders and Borrowers, Policy Paper No. 20/010, Washington: IMF and World Bank. Available at https://www.imf.org/en/Publications/Policy-Papers/Issues/2020/02/19/Collateralized-

Transactions-Key-Considerations-for-Public-Lenders-and-Borrowers-49063

Jenks, Leland H. 1927. The migration of British capital to 1875. Alfred A. Knopf, New York.

Jerven, Morten. 2013. Poor numbers: How we are misled by African development statistics and what to do about it. Cornell University Press.

Jiménez, Gabriel, Vicente Salas, and Jesús Saurina. 2006. “Determinants of collateral.” Journal of Financial Economics, 81 (2):255-281.

Kiyotaki, Nobuhiro and John Moore. 1997. "Credit cycles.” Journal of Political Economy, 105 (2):211-248.

Kleiber, Christian, Kurt Hornik, Friedrich Leisch, and Achim Zeileis. 2002. "strucchange: An R package for testing for structural change in linear regression models." Journal of Statistical Software, 7 (2):1-38. Klovland, Jan Tore. 1994. "Pitfalls in the Estimation of the Yield on British Consols, 1850-1914." Journal of Economic History, 54 (1) :164-187.

La Porta, Rafael, Florencio Lopez-de Silanes, Andrei Shleifer, and Robert Vishny. 2000. "Investor protection and corporate governance.” Journal of Financial Economics, 58 (1- 2):3-27.

Landes, David S. 1958. Bankers and pashas: International finance and economic imperialism in Egypt. Harvard University Press. 
Li, Xindan, Avanidhar Subrahmanyam, and Xuewei Yang. 2018. "Can financial innova tion succeed by catering to behavioral preferences? Evidence from a callable options market." Journal of Financial Economics, 128 (1):38-65

Lobban, M. 2006. "Erlanger v New Sombrero Phosphate Co. (1878)." In Landmark Cases in the Law of Restitution, edited by Charles Mitchell and Paul Mitchell. Oxford: Hart, 123-62.

López-Morell, Miguel A. 2016. The House of Rothschild in Spain, 1812-1941. Routledge.

Martín, Victoriano M. 1980. Los Rothschild y las minas de Almadén. Universidad Complutense de Madrid.

Marichal, Carlos. 1989. A Century of Debt Crises: From Independence to the Great Depression, 1820-1930. Princeton University Press.

Miao, Meng, Guanjie Niu, and Thomas Noe. 2021. "Contracting without contracting institutions: The trusted assistant loan in 19th century China." Journal of Financial Economics, 140 (3):9871007.

Ministerio de Gracia y Justicia. 1861. Ley hipotecaria: Reglamento General para su ejecución e Instrucción sobre la manera de redactar los instrumentos públicos sujetos a registro. Madrid: Imprenta del Ministerio de Gracia y Justicia.

North, Douglass C. and Barry R. Weingast. 1989. "Constitutions and commitment: the evolution of institutions governing public choice in seventeenth-century England." Journal of Economic History, 49 (4): 803-832.

North, Douglass C et al. 1990. Institutions, institutional change and economic performance. Cambridge university press.

Novy-Marx, Robert and Joshua D. Rauh. 2012. "Fiscal imbalances and borrowing costs: Evidence from state investment losses." American Economic Journal: Economic Policy, 4 (2):182-213.

Pantoja, José María and Antonio M. Lloret. 1861. Ley hipotecaria, comentada y explicada, vol. 1. L. López.

Peña-Mir, José Luis. 2019. Financiación y especialización productiva: el mercado de crédito malagueno a finales del siglo XVIII. Investigaciones De Historia Económica, 12 (3): 133-143.

Ryall, Michael D., and Rachelle C. Sampson. 2009. "Formal contracts in the presence of relational enforcement mechanisms: Evidence from technology development projects." Management Science, 55 (6): 906-925.

Rose, Philip and John Staniforth. 1876. Turkish Debt; Report of Sir Philip Rose and Mr. John Staniforth, on the Results of their Mission to Constantinople. London: Harrison.

Shee, M. A. 1876. "The Turkish loan of 1854", s.n., Available from JSTOR/Bristol Selected Pamphlets.

Simonsohn, Uri, Joseph P. Simmons, and Leif D. Nelson. 2020. "Specification curve analysis." Nature Human Behaviour, 4 (11): 1208-1214.

Smith, Clifford W. Jr. and Jerold B. Warner. 1979. "On financial contracting: An analysis of bond covenants." Journal of Financial Economics, 7 (2):117-161.

Steinberg, S. H. 1966. "Statesman's Year-Book: Martin to Epstein.” The Journal of Library 
History, 1 (3):153-166.

Story, Joseph. 1839. Commentaries on the Law of Agency: As a Branch of Commercial and Maritime Jurisprudence, With Occasional Illustrations from the Civil and Foreign Law. Boston: Little.

Taylor, James. 2013. "Privacy, publicity, and reputation: How the press regulated the market in nineteenth-century England." Business History Review, 87 (4): 679-701.

Vammale-Sabouret, Camila. 2008. De la naissance de la dette publique au plafond souverain: rôle des gouvernements régionaux dans l'évolution de la dette publique, Unpublished Dissertation, Institut d'Etudes Politiques, Paris.

Veldkamp, Laura L. 2006. "Media frenzies in markets for financial information." American Economic Review, 96 (3):577-601.

Vizcarra, Catalina. 2009. "Guano, credible commitments, and sovereign debt repayment in nineteenth-century Peru." The Journal of Economic History 69 (2):358-387.

Vührer, A. (1886). Histoire de la Dette Publique en France. Paris : Berger-Levrault.

Vuillemey, Guillaume. 2020. "The value of central clearing." The Journal of Finance, 75 (4):2021-2053.

Westlake, John. 1858. A Treatise on Private International Law: Or the Conflict of Laws, with Principal Reference to Its Practice in the English and Other Cognate Systems of Jurisprudence. W. Maxwell.

Weidemaier, Mark C. 2012. "Reforming sovereign lending practices: Modern initiatives in historical context." No. 1996763. UNC Legal Studies Research Paper

Zeileis, Achim, Christian Kleiber, Walter Krämer, and Kurt Hornik. 2003. "Testing and dating of structural changes in practice." Computational Statistics \& Data Analysis, 44 (1-2):109-123. 